The Return of the Native (Veteran): Six Nations Troops and Political Change at the Grand River Reserve, 1917-1924

by

John Moses, Bachelor of Arts

A thesis submitted to the Faculty of

Graduate Studies and Research in partial fulfillment

of the requirements for the degree of

Master of Arts

in Canadian Studies

Carleton University

OTTAWA, Ontario

(28 March 2008)

c. 2008, John Moses 


$\begin{array}{ll}\begin{array}{l}\text { Library and } \\ \text { Archives Canada }\end{array} & \begin{array}{l}\text { Bibliothèque et } \\ \text { Archives Canada }\end{array} \\ \begin{array}{l}\text { Published Heritage } \\ \text { Branch }\end{array} & \begin{array}{l}\text { Direction du } \\ \text { Patrimoine de l'édition }\end{array} \\ \begin{array}{l}\text { 395 Wellington Street } \\ \text { Ottawa ON K1A 0N4 } \\ \text { Canada }\end{array} & \begin{array}{l}\text { 395, rue Wellington } \\ \text { Ottawa ON K1A 0N4 } \\ \text { Canada }\end{array}\end{array}$

Your file Votre référence ISBN: 978-0-494-40606-9 Our file Notre référence ISBN: 978-0-494-40606-9

NOTICE:

The author has granted a nonexclusive license allowing Library and Archives Canada to reproduce, publish, archive, preserve, conserve, communicate to the public by telecommunication or on the Internet, loan, distribute and sell theses worldwide, for commercial or noncommercial purposes, in microform, paper, electronic and/or any other formats.

The author retains copyright ownership and moral rights in this thesis. Neither the thesis nor substantial extracts from it may be printed or otherwise reproduced without the author's permission.
AVIS:

L'auteur a accordé une licence non exclusive permettant à la Bibliothèque et Archives Canada de reproduire, publier, archiver, sauvegarder, conserver, transmettre au public par télécommunication ou par l'Internet, prêter, distribuer et vendre des thèses partout dans le monde, à des fins commerciales ou autres, sur support microforme, papier, électronique et/ou autres formats.

L'auteur conserve la propriété du droit d'auteur et des droits moraux qui protège cette thèse. $\mathrm{Ni}$ la thèse ni des extraits substantiels de celle-ci ne doivent être imprimés ou autrement reproduits sans son autorisation.
In compliance with the Canadian Privacy Act some supporting forms may have been removed from this thesis.

While these forms may be included in the document page count, their removal does not represent any loss of content from the thesis.
Conformément à la loi canadienne sur la protection de la vie privée, quelques formulaires secondaires ont été enlevés de cette thèse.

Bien que ces formulaires aient inclus dans la pagination, il n'y aura aucun contenu manquant.

\section{Canada}




\title{
The Return of the Native (Veteran): Six Nations Troops and Political Change at the Grand River Reserve, 1917-1924
}

\begin{abstract}
This thesis presents the author's research into the impacts of Canada's involvement in the First World War on political leadership at the Six Nations of the Grand River Reserve. In 1924 the traditional council of Confederacy Chiefs was replaced as the governing body by an elected band council, organized as per Indian Act regulations. Today, prevailing ideology maintains that this change occurred as an intervention of the federal government to speed Native assimilation. The historical record reveals other forces at work, including Six Nations veterans of the First World War. The thesis posted here is that the implementation of elected band council government on the Six Nations of the Grand River occurred at the instigation of a small but vocal minority of Six Nations residents themselves, and that newly returned Six Nations veterans of the Great War constituted an elite body at the forefront of this movement advocating political change.
\end{abstract}




\section{Acknowledgements}

I wish to thank the librarians and staff of Library and Archives Canada, and the Canadian Museum of Civilization, for directing me to many of the research materials used in the writing of this thesis. I also wish to thank my external readers and examiners, and my thesis supervisors, Donna Patrick and Paul Litt, for their valuable insights. I wish to thank my parents Russ and Helen, and my wife Denise, for much support during early mornings and late evenings. Finally, I dedicate this thesis to our daughter Quinn Kateri, that she may know more of her Grand River heritage. 
The Return of the Native (Veteran): Six Nations Troops and Political Change at the Grand River Reserve, 1917-1924

\section{Table of Contents}

Title Page

Abstract

ii

Acknowledgements

iii

Table of Contents

iv

A Note on Terminology and Usage

V

Introduction: Defining the Research Question p. 1

Chapter 1: Six Nations of the Grand River in Political and Military Context

p. 17

Chapter 2: Six Nations Governance and the Rise of the Dehorners p. 38

Chapter 3: Six Nations of the Grand River in the First World War p. 52

Chapter 4: The Return of the Six Nations Veterans and the Implementation of Band Council Rule

p. 80

Summary \& Conclusions: The Sovereignty Question

p. 109

Endnotes

p. 113

References

p. 118 


\section{A Note on Terminology and Usage}

First Nations, Inuit and Métis communities across Canada are asserting the right to be known by those indigenous language names by which they have customarily identified themselves. Often these do not correspond to those names formerly appearing within the anthropological or historical literature, or as previously recognized by the federal government. In addition, other completely original terminologies are coming into use to reflect continuing political or cultural developments within these constituencies.

Throughout this thesis, where the reader is more likely to recognize an English or French-language usage rather than an Aboriginal equivalent, specific groups or communities are referred to by their more commonly recognized English or Frenchlanguage designations, while specific individuals are identified with the names by which they most commonly appear in the historical record. For example, "Mohawk leader Joseph Brant remained principal spokesperson for the Six Nations of the Grand River territory until his death in 1807."

Aboriginal is used as per its definition under section 35, the Constitution Act 1982, as an inclusive term identifying the Indian, Inuit and Métis populations of Canada. Indian remains a legal term insofar as there remains in force the federal legislation of the Indian Act, and the continuing mandate of the federal department of Indian and Northern Affairs Canada. Indian also remains in everyday use among significant Aboriginal constituencies themselves, as with the Federation of Saskatchewan Indian Nations, and the Union of British Columbia Indian Chiefs. First Nations is more recent terminology dating from 1981 when the former National Indian Brotherhood formally changed its name to the Assembly of First Nations. This was largely in response to the "two founding 
nations" (French and English) political rhetoric which characterized constitutional patriation debates of that era. First Nations is now typically used to identify those communities of status Indian residing on Indian reserves, and their ancestral populations. However, a number of communities avoid this terminology, concerned that it implies political representation by the Assembly of First Nations, when this may not be the case. Non-status Indians are those individuals of Indian background whose ancestors for whatever reason were never formally registered or recognized legally as "status" Indians by the federal government, or who otherwise lost their status under outdated and now repealed provisions of the Indian Act. Registered band members are those status Indians who, in addition to their federally recognized status, are inscribed members of a specific Indian reserve. Under some circumstances, it is possible that a person enjoys legal Indian status, but not registered band membership, or vice versa. In this thesis, Native may be used occasionally to refer collectively to status and non-Status Indian persons, or groups.

Métis are those Aboriginals of mixed racial background who self-identify neither as Indian or Inuit. There are distinct Métis populations across all regions of Canada, including, for example, the mixed Inuit-white "Settler" populations along the Labrador coast, the Dene-Métis groups of the Yukon and Northwest Territories, and the Anishnaabe-white population of the Ottawa River Valley, as well as the Métis nation of the West. Those Métis today who are descendants of the Red River Métis and who remain heirs to the political legacy and tradition of Louis Riel are just one element of the diverse Métis populations of Canada. 
The Inuit are the indigenous people of the Canadian Arctic, formerly often called "Eskimos" by southerners and outsiders. They are racially, culturally and linguistically distinct from other Aboriginal peoples in Canada. Variants of their language, Inuktitut, are spoken from the Russian Arctic eastward across the circumpolar regions to Greenland, making it the most widely spoken indigenous language on the globe. 


\section{Introduction: Defining the Research Question}

Demands by some Native protesters and their supporters in the continuing land dispute between Six Nations band members, Caledonia residents, real estate developers, and government representatives over the Douglas Creek Estates housing development in southern Ontario include calls for a return to governance by a Six Nations council of hereditary chiefs. Insofar as this demand challenges the legitimacy of the system of governance by elected band councils which has been in place at Six Nations since 1924, it is timely to interrogate the assumptions underlying it. This means examining the circumstances under which the traditional form of government was superseded by a nontraditional form in this Indian reserve community. Prevailing ideology today maintains that this change occurred due to a unilateral government intervention to speed assimilation, in accordance with the overall thrust of historic Indian policy and legislation of that era. The historical and documentary records, however, reveal other forces at work, including the participation of Six Nations veterans of the First World War.

The research question at the heart of this thesis is: To what extent were newly returned Six Nations veterans of the First World War instrumental in having the traditional system of hereditary chiefs on the Six Nations of the Grand River Indian Reserve replaced with an elected system of band council chiefs in $1924 ?^{1}$ A historical and sociological analysis of events in this Indian reserve community during the time period 1917 to 1924 will provide an answer to this question. As we shall see, increasingly vocal assertions of sovereignty by Six Nations traditionalists and supporters of the hereditary chiefs were an international embarrassment to a Canada trying to assert its own autonomy during the post-First World War period. A group within the Six Nations community, the 
Dehorners, had campaigned against government by hereditary chiefs for decades. Veterans were prominent within the Dehorner movement. In the immediate postwar era their reform agenda coincided with the interests of an increasingly autonomous Dominion of Canada.

A major goal of this thesis research is to set the governance change of 1924 within its longer-term historical context. Democratically elected band council government was a long-term goal of the Dehorners, reformers active in Six Nations politics from the mid-nineteenth century on. The sons and grandsons of the founders of the original reform movement became active in militia affairs, and volunteered for service with the Canadian Expeditionary Force (CEF) during the Great War, against the wishes of the hereditary chiefs. This thesis examines how, while overseas, their reform ideology became intensified, and influenced their actions after their return to the reserve in 1919. In the hyper-nationalistic and patriotic environment of postwar Canada, these newly returned Six Nations veterans capitalized upon their status as Dominion Great War veterans, and upon the ideal of the warrior tradition within orthodox Haudenosaunee or Iroquois culture, something which neither the hereditary chiefs nor their stay-at-home supporters of military age could legitimately claim. During the early decades of its existence the reform movement received little support from the Dominion government because it was a minority voice on the reserve. However, the veterans' esteemed status in postwar Canadian society, despite their continued minority standing, coincided with a new government willingness to implement political change at Grand River. This conjunction of interests emboldened both the reform-minded veterans and the Canadian 
state to forge ahead in advancing what had become their shared agenda in removing the hereditary chiefs from power.

"Returned soldiers" was the term most commonly used for newly returned veterans following the First World War. Until subsumed into the more moderate Royal Canadian Legion and British Empire Service League, their most militant advocacy group was the Great War Veterans Association (GWVA). The most controversial demand of the GWVA was for a $\$ 2000$ bonus to be awarded each returned veteran upon repatriation. Individually and collectively veterans were volatile entities, and their postwar allegiances spanned the political spectrum from left to right. During the strikes and riots of 1919, the largest of which was the Winnipeg General Strike, some veterans participated in assaults against immigrant workers and union leaders, while others emerged at the forefront of the labour movement. ${ }^{2}$ Following the war, organized bodies of veterans were viewed as a potential threat by governments and their national security apparatuses in countries around the world. As will be shown, status Indian veterans in Canada, and those members of the Six Nations of the Grand River in particular, were recognized at the time as forming a unique subset within the broader Canadian returned soldiers movement. The newly returned Six Nations veterans of the Great War constituted an elite body within a preexisting reform movement advocating profound political change. ${ }^{3}$ Dehorner petitions of 1861 and 1907 discussed below, calling for removal of the Confederacy Chiefs, garnered 167 and 300 signatures respectively; while the 1917 Soldiers' Petition and 1919 Veterans' Petition demanding the same action bore 57 and 32 signatures respectively. ${ }^{4}$ The total population of the Six Nations of the Grand River numbered 4,466 persons in $1911 .^{5}$ Thus the 1924 implementation of elected band council 
government on the Six Nations of the Grand River Indian Reserve occurred at the instigation of a small but vocal reform-minded minority of Six Nations residents. Their postwar reform demands received a sympathetic hearing from the government because of its own concerns about Six Nations at the time. However, the abolition of government by hereditary chiefs was not solely the result of unilateral government intervention to speed its own assimilationist agenda. It had the support of a credible group within Six Nations.

Before investigating this issue, it is necessary to define some key terms and concepts. Some Native Canadians have developed and espouse a post-colonial indigenous political doctrine as a response to Britain's (and later Canada's) refusal to recognize Aboriginal sovereignty. This doctrine, defined here as Native grievance ideology, manifests itself in continuing efforts today by contemporary activists to reassert this sovereignty. The term ideology is used in this thesis in its broadest sense to denote underlying premises, beliefs, or assumptions which condition core values and attitudes and can motivate individuals or groups to action. ${ }^{6}$ The term Native grievance ideology is thus used to describe the theoretical construct which guides contemporary Six Nations activists who make claims for restitution and sovereignty. Their demands include calls for the return of alienated lands and a reversion to traditional governance by Confederacy Chiefs, the removal of which by Dehorners and Six Nations veterans is the subject of this thesis. The principal features of the ideology of Native grievance include demands for leadership by traditional authority, and unfettered autonomy and self-determination for First Nations polities within the Canadian federation, if not total sovereignty as independent nation-states at the level of public international law. Implicit within this is a 
denial of the competence of Canada to legislate on behalf of, or otherwise intrude upon, matters pertaining to First Nations.

The canonical documents of Native grievance ideology include the range of Peace \& Friendship treaties, the Royal Proclamation of 1763, the later Land Cession and Surrender Treaties (including the Robinson Treaties and the Numbered Treaties), plus the Indian Act, its colonial precursors, and its subsequent amendments. Its associated phenomena include the implementation of Indian reserves, the residential school experience, the rise of contemporary urban Aboriginal populations, court decisions, the modern land claims process (including both specific and comprehensive claims, and the respective Commissions implemented to consider these), constitutional enshrinement of Aboriginal and treaty rights, the generally disadvantaged socio-economic circumstances of Aboriginal peoples in Canada as compared to the Canadian mainstream as most recently articulated in the 1996 Final Report of the Royal Commission on Aboriginal Peoples (RCAP), and the accommodation of Aboriginal traditional knowledge within public policy and related decision-making. Within the particular context of Grand River, the Haldimand Deed, the Simcoe Patent, subsequent reductions of the original land base, the concomitant loss of band funds, and finally the 1924 removal of the hereditary council of Confederacy Chiefs, are touchstones of Native history generally and, in particular, Native grievance ideology.

Colonialism itself may be described as the international relations and foreign policy of modernity. To the extent that a major metanarrative of modernity is premised upon an assumed superiority of the West and the subjugation of lesser races as a preordained historical outcome, then the West has a moral obligation to bring the rest of 
the world within its purview. The imposition of colonial rule over indigenous and tribal populations included the replacement of Aboriginal customary law traditions with common law or civil code traditions; and a fundamental reordering of basic social and cultural values, wherein private property and individual rights became dominant over indigenous legal traditions and oral constitutional systems which typically privileged property held in common and group rights as dominant societal values. In this respect, post-colonialism may be seen as an initiative within the broader category of postmodernism, undertaken primarily by (formerly) colonized indigenous peoples themselves, or their modern-day descendant populations, to refute modern (and colonial) metanarratives of white Western supremacy and ascendancy, and reassert traditional indigenous values and norms, as these are manifested across the spectrum of social organization including law, governance, property and human rights, art and culture, language, and traditional knowledge.

Post-colonial history may be seen as history written from the perspective of or by the descendants of formerly colonized indigenous populations, as opposed to previous historical narratives written from the outside, by colonial administrators, intellectuals, and other elites. Some of the more obvious, quantifiable aspects of the colonial project historically involved both a physical and legal separation of colonized indigenous peoples from the mainstream settler population within a given colony. Within the Canadian context, for example, this took the form of the implementation of both a system of Indian reserves and residential schools, thus accomplishing physical separation; while the implementation of a government-determined system of official Indian status and band 
membership as described in the Indian Act provided the legislative framework for separation.

The terms nation, state, nation-state, and sovereignty are used in a straightforward sense in this thesis. The concept of the nation implies a shared characteristic, or set of characteristics, amongst a group of people who by common consent accept this as the basis of their group self-identification. These characteristics can include their common linguistic, ethnic or religious heritage, or combinations of these. The concept of the state or nation-state as used in this thesis is based upon that definition described in the 1933 Montevideo Convention on Rights and Duties of States, and refers to the geopolitical entity enjoying international recognition as such by the global community of other states and nation-states, with permanent borders defining a specific territory, a stable population accepting its citizenship, economic infrastructure capable of providing gross domestic product, and other infrastructure necessary for security and defence. ${ }^{7}$ Sovereignty is a doctrine pertaining to international relations in which fully independent states or nationstates are the primary political actors, autonomous in their foreign policy in relation to other states and nation-states, and with exclusive jurisdiction with respect to their internal affairs.

Lying at the point of intersection of ideas concerning sovereignty and the state or nation-state is land, its title and its tenure. George III's Royal Proclamation of 1763 looms large in this research. It was through the alienation of title to Indian lands in a treaty process first articulated in the Royal Proclamation that Aboriginal sovereignty was incrementally extinguished across what is now Canada. This process continues today in the negotiation of contemporary land claims. Thus land title disputes ultimately relate to 
the fundamental issue of sovereignty. As will be shown, despite other assertions to the contrary, the Royal Proclamation was basically the application of the English common law of property, and the rights of land holders, to Indian policy in British North America. Neither it nor any of its derivative decrees can be construed as recognizing, either implicitly or explicitly, continuing Aboriginal sovereignties. ${ }^{8}$

As Canada approaches the $90^{\text {th }}$ anniversary of the end of the First World War in 2008 (a pivotal event for Canada, seen as key in our national development as a sovereign state), Canadian historiography is undergoing a reassessment, if not revision, of our national role in that conflict, and of the impact of that conflict upon our subsequent evolution. ${ }^{9}$ As the Great War had a profound impact upon Canada in general, so too did it have a profound impact upon Indian reserve communities across Canada; perhaps nowhere else more so than on Canada's most populous Indian reserve community (then, as now), the Six Nations of the Grand River Reserve near Brantford, Ontario. The impacts of the Great War upon political and other aspects of life on this reserve were profound, and these continue to echo today. These impacts, and community responses to them, merit examination in greater critical detail than has thus far been the case. Previous thesis research in this field by other writers, conducted before the current Caledonia dispute and the renewed calls for a reversion to hereditary leadership, have not been produced by Six Nations band members themselves, and have discussed the potential role of the Six Nations veterans in the events of 1924 only in passing. ${ }^{10}$ James E. Benincasa (1994), in Cultural Divisions and the Politics of Control: The Canadian Removal of the Six Nations' Hereditary Council in 1924, discusses the 1924 change in governance within the context of a "Berkhoferian" model of political control; while Scott R. Trevithick 
(1998), in Conflicting Outlooks: The Background to the 1924 Deposing of the Six Nations Hereditary Council, focuses upon the Dominion government's deteriorating relationship with the Confederacy Chiefs over several decades.

This thesis uses historical methodology insofar as it presents documentary sources as evidence and conducts careful analysis of these key written texts. It also relies on insights from sociology about the impacts of elite groups within communities. An ethnographic analysis of wampum belts, a significant category of Iroquois material culture pertaining to political relations, is employed. Discourse analysis is used to examine differing notions of sovereignty of different groups. As described above, the idea of Grand River sovereignty espoused during wartime by the traditional clanmothers and chiefs within Confederacy Council was profoundly different than that articulated by the nearly 300 much more acculturated Grand River band members who were serving on the Western Front in the armed service of the British Empire. ${ }^{11}$ Quantitative methods include analysis of records and statistics pertaining to national enlistment figures for status Indians during wartime, the names appearing on regimental and sailing lists, and the names appearing on petitions.

Research for this thesis was conducted in the records in RG 10 (Indian Affairs) at Library and Archives Canada (LAC). These records document the administration of Indian affairs on the Six Nations Reserve during the time period under review. The Elliott Moses papers (MG 30, C 169, Finding Aid No. 1109), also at LAC, provided a trove of first-hand information concerning the history of the Dehorner movement by one its leaders (and the son of a founding member) during the events of 1924. Key primary sources used in this thesis included the Clanmothers' Petition of 1917, the Soldiers' 
Petition of 1917, the Veterans' Petition of 1919, and the 1923 Commissioner's Report, the findings of which were published in 1924. The Clanmothers' Petition provides as dramatic and concise a statement of the Six Nations' view of their own claim to sovereignty, autonomy and self-determination as any other ever committed to paper and available to researchers today. Its use of both text and the iconography of wampum symbolism is a unique fusion of the written record with the Iroquois oral tradition. An equally powerful statement of the claims, grievances and ideology of that surviving portion of the Six Nations troops who assumed control of the Dehorner movement is found in their 1919 Veterans' Petition, in which they signal their intention to resume their agitation against the Confederacy Chiefs. The Commissioner's Report published in 1924 is the final report of the commissioner appointed to investigate the affairs of Six Nations during the immediate postwar era, including renewed agitation by the Dehorners and the Six Nations veterans, and it signals the Dominion government's new postwar willingness to intervene decisively in internal Six Nations politics on the side of reform.

Additional primary sources included the Annual Report for the Department of Indian Affairs for the fiscal year ending 31 March, 1919, and an article by Duncan Campbell Scott (1919), entitled "The Canadian Indians in the Great World War". Both of these include discussion not only of Six Nations' actual wartime participation, but also of the returned veterans' postwar political agenda. John A. Noon (1949), Law and Government of the Grand River Iroquois, and Annemarie Shimony (1961), Conservatism Among the Iroquois at the Six Nations Reserve, are mid-twentieth century anthropological studies of Six Nations which describe the 1924 political change with reference to the participation of the veterans. Sally Weaver (1975), Iroquois Politics 
1847-1940, is an especially useful compendium of source material, including the complete text of the numerous petitions and memorials being sent to government from both Confederacy and Dehorner supporters from roughly 1840 through 1940 . Weaver (1994a) and (1994b) are published distillations of the voluminous information contained in Weaver (1975), which remains an unpublished manuscript.

Secondary sources have included Fred Gaffen (1985), Forgotten Soldiers and Janice Summerby (2005), Native Soldiers, Foreign Battlefields, second edition. These are popular commemorative works for a general audience, providing much anecdotal information concerning the service records of individual Six Nations band members, and other Aboriginals from across the country. The most recent treatment of this subject matter is P. Whitney Lackenbauer and Craig Leslie Mantle, Eds. (2007), Aboriginal Peoples and the Canadian Military: Historical Perspectives, an anthology of papers presented at a military history conference held at the Royal Military College in Kingston in June 2006 entitled "Aboriginal Peoples and the Canadian Military: Past, Present, Future". Indeed chapter 5 in that volume is a published version of the thesis proposal that led to this thesis. ${ }^{12}$

Since these postwar events can only be understood within their historical context, this thesis provides historical background on the military tradition of the Six Nations. It then focuses on the actions of Six Nations veterans of the Great War on the Grand River Reserve from 1917 to 1924 , culminating in their successful bid to have the hereditary system of chiefs replaced by an elected band council, as per Indian Act provisions of the day. Nineteen seventeen is taken as the starting point because this is the year the Six Nations veterans (actually, at that time, still serving combat troops in the frontline 
trenches) coalesced as a distinctive political entity and submitted their first petition from France.

This thesis will not deal in any significant way with the national Native political lobby of that era - the League of Indians of Canada, established in 1919 - despite the Six Nations origin and veteran status of its founder, F.O. Loft; nor with developments at other Iroquois reserves, such as Caughnawaga (Kahnawake). Nor will it deal with events on any other reserves elsewhere in Canada. Primary source documents including petitions from supporters of both hereditary and elected systems of government have been canonical. It is not the intention of this research to show that the Six Nations veterans were the only driving force for political change during the 1917-1924 time period, but rather to demonstrate that they constituted an elite body within a preexisting reform movement, and that they undertook decisive action at a critical juncture in furtherance of their aims.

This research project thus uses an interdisciplinary approach to deconstruct and critique a conventional metanarrative of Canada during the first quarter of the $20^{\text {th }}$ century. In past accounts, Native peoples were situated as the passive wards of the Canadian state, incapable of formulating, articulating, and advancing their own agendas for change. In particular, this research interrogates a specific sub-topic within the prevalent ideology of Native grievance and oppression - the implementation of elected band council governance at the Six Nations Reserve in 1924. Whereas the prevailing orthodoxy of Native victimization in this case is premised upon a mythology of unilateral federal government intervention to oust the traditional Iroquois system of hereditary chiefs, and arbitrarily impose an elected system of Indian Act band council chiefs against 
the wishes of the reserve population, and thus speed assimilation, a particular body of documentary evidence indicates that, on the contrary, the Dominion government was reluctant to intervene in Six Nations affairs for many decades, only did so when provoked, and even then acted in concert with a credible political group within Six Nations.

To the extent that the hereditary chiefs can be characterized as ineffective political actors on behalf of the Six Nations (insofar as it was precisely under their administration that the original Grand River land base was so dramatically reduced), one could argue that successive colonial and then Dominion governments should have been quite eager to see their mandate continue. Indeed, given such a reading, it would have been irrational for government authorities to support the forced introduction of a democratically elected and publicly accountable Native government, thereby replacing a hereditary system that apparently was much more amenable to the white settler society's long-term interests in alienating the Grand River lands. ${ }^{13}$ Finally, political activism on the part of Six Nations' own newly returned Great War veterans was the cutting edge of a militant movement among a dissident minority of Six Nations band members styling themselves the Dehorners, which had been agitating for political change for some decades previous, as the result of long-standing dissatisfaction with the status quo represented by the hereditary system of Confederacy Chiefs.

Given the cultural implications of this governmental reform, its ultimate implementation resulted in a fundamental paradigm shift whose impacts were profound. It reinforced an already existing split between supporters of the traditional system of hereditary chiefs and supporters of democratic governance, a division which (despite 
sometimes fluid boundaries) continues to define the Six Nations Reserve to the present day. This approach will thus challenge the dominant Native-as-victim paradigm which has become orthodoxy within conventional Native Studies/Canadian Studies discourse, but which unwittingly denies the possibility of Native agency. ${ }^{14}$ Despite the passage of 90-odd years, the subject matter of this research project remains sensitive within the Six Nations community, insofar as it findings will challenge certain long-held beliefs concerning the means by which band council elections were introduced in 1924 .

As a disclosure of potential or perceived bias, it is necessary to state that the author of this thesis research is a registered member of the Delaware band of Indians at the Six Nations of the Grand River Reserve, and is himself a five-year veteran of Canadian military service. He is the great-grandson and grand-nephew, respectively, of leading Dehorners Nelson Moses, and sons James, Elliott, and Arnold Moses, referred to in the text. Conversely, however (and indicative of the complex nature of Grand River politics), through his maternal line (which is Upper Mohawk band), he is also grandnephew of the late Arthur Anderson senior, long-time recording secretary to the Confederacy Chiefs from the 1920's through 1960's, and a leading member of the sovereigntist Mohawk Workers party at Six Nations ${ }^{15}$. Given the nature of this thesis research, this insider perspective is seen to enhance rather inhibit objective inquiry into this subject matter. Additionally, it allows for the incorporation of certain materials, best described as family heirlooms (including wartime letters, photographs, and other printed material), that help bring the past discussed here alive.

This research will allow for a more subtle, nuanced, and sophisticated reading of political events which transpired on the Six Nations of the Grand River Reserve in 1917- 
1924. In so doing, it will challenge established orthodoxies within the mainstream Canadian Studies and Native Studies projects, which entrench a national metanarrative inside of which Native subjects are typically portrayed as the complacent targets or oppressed victims of unilateral federal action. This research will fill gaps in the existing literature of Canadian military history, Native Studies, and Canadian Studies by demonstrating agency and independent action on the part of Six Nations veterans of the Great War (including demobilized soldiers and ex-officers) in successfully agitating for political change on that reserve, thus establishing their status as an elite body within a preexisting movement for democratic reform, styled the Dehorners.

This thesis has been organized in the following sections,

- "Introduction: Defining the Research Question", to introduce the specific topic of this thesis research, to define key terms, review relevant literature in the field, and explain methodology.

- "Chapter 1: Six Nations of the Grand River in Political and Military Context", to provide an Aboriginal context to Canada's military heritage, and to situate the Six Nations of the Grand River within this history.

- "Chapter 2: Six Nations Governance and the Rise of the Dehorners", to provide background on the origins of political divisions at Grand River, and to introduce the primary actors: the Confederacy Chiefs and the Dehorners.

- "Chapter 3: Six Nations of the Grand River in the First World War", to provide specific information concerning the place of the Six Nations of the Grand River in Canada's First World War military effort; and how this global event crystallized already existing conflicts between the Confederacy Chiefs and their supporters, 
and the Dehorners and their supporters, including those troops overseas who subsequently manifested Dehorner ideology.

- "Chapter 4: The Return of the Six Nations Veterans and the Implementation of Band Council Rule", to describe the Six Nations veterans' assumption of leadership within the Dehorner movement, their subsequent campaign to challenge Confederacy rule, and their ultimate collusion with the Dominion government to terminate the mandate of the Confederacy Chiefs.

- "Summary \& Conclusions: The Sovereignty Question", to summarize the findings of this thesis research. 


\section{Chapter 1: Six Nations of the Grand River in Political and Military Context}

The primary concern of this thesis research is the political ramifications of Great War military service by Six Nations band members who subsequently manifested Dehorner ideology. However, insofar as from the mid-nineteenth century onward so much of the daily life of Aboriginal peoples was circumscribed by government legislation including the federal Indian Act, the Great War experiences of Six Nations band members cannot be discussed in isolation from their broader political context. It was the knowledge of their unique legal status as Indian people within the Canadian state, as per the Indian Act and other related legislation, which often determined the extent to which Aboriginal communities and reserve populations, including Six Nations, considered their members at all obligated to perform military service. During both World Wars various government officials, including civilian Indian agents and military recruiters, were initially concerned about whether status Indian applicants could be enlisted legally. After all, from the legislative point of view, they possessed the status of legal minors and government wards. A brief history of Aboriginal involvement in Canada's military is necessary as context for understanding the motivations of those Six Nations band members who did volunteer in 1914-1918.

The Six Nations of the Grand River Territory was established in 1784 by the terms of the Haldimand Deed, dated 25 October of that year. The land grant was awarded as compensation for Six Nations lands which were lost to the Americans during the American Revolution. The original terms and conditions of the Haldimand Deed were later confirmed in the Simcoe Patent of 14 January 1793. The original extent of the Haldimand Tract itself was but a portion of a larger area purchased from the Mississauga by the British Crown on 22 May 1784, in accordance with principles and procedures 
articulated in the Royal Proclamation of 1763 . The assertion of Crown sovereignty over British North America made explicit in the Royal Proclamation of 1763, the delegation of Indian affairs as a federal responsibility in the British North America Act of 1867, and the application of the first consolidated Indian Act of 1876 provided the constitutional and legislative context for the events described herein.

The Six Nations of the Grand River community has been and remains the subject of scrutiny by historians, anthropologists, and other social scientists. The history of this community remains open to reassessment and revision as new research materials periodically come to light. No discussion of Upper Canadian or early Ontario history may be considered complete without some mention of their considerable presence. The Six Nations of the Grand River Indian Reserve is located in southern Ontario, near Brantford. Although known as the Six Nations Reserve, its membership in fact incorporates 13 distinct bands: Lower Cayuga, Upper Cayuga, Delaware, Bay of Quinte Mohawk, Lower Mohawk, Upper Mohawk, Walker Mohawk, Oneida, Bearfoot Onondaga, Clear Sky Onondaga, Konadaha Seneca, Niharondasa Seneca, and Tuscarora. ${ }^{16}$ Additionally, over the span of the generations since the Reserve's founding in 1784 , there has been significant intermarriage with non-Natives and with other Native groups from across southern Ontario. Also, at the time of its founding, smaller bands of other Native groups were present, including Tutelo, Nanticoke, Delaware, Shawnee, Cherokee, and Pequot. However, following the first 2 or 3 generations of intermarriage into the larger bands, with the exception of the Delaware, these smaller groups had ceased to exist as separate entities. The standard ethnography of the composite Munsee-Mahican band of Delaware at Six Nations remains The Celestial Bear Comes Down to Earth (Speck and Moses, 
1945). Additionally, a short story by E. Pauline Johnson, "The Delaware Idol”, appearing in her 1913 collection The Shagganappi, while fictionalized, provides one account of the circumstances under which the mass religious conversion of the Grand River band of Delaware to Christianity took place around 1850. A privately printed memoir appearing in 1971, The Life Story of My Grandparents (Montour, 1971) provides further insights into the ethnohistory of this group which, as a non-Iroquois refugee band at Grand River, in essence as a minority within a minority within the Six Nations of the Grand River territory, was to be at the forefront of the Dehorner movement. The Feathered U.E.L's (Montour, 1973) likewise offers additional anecdotal information concerning the Delaware band at Six Nations.

The responses of Aboriginal populations generally to regional and global military affairs, and the degree to which imperial or colonial authorities sought their aid or encouraged their neutrality, historically provide a barometer of the larger environment within which Aboriginal/non-Aboriginal political, legal, and economic relations on this continent were forged. Pontiac's rebellion in the aftermath of the demise of the French regime in eastern North America influenced George III to include in his Royal Proclamation of 1763 specific reference to Aboriginal title and rights which today are enshrined in the Canadian Charter of Rights and Freedoms and elsewhere in the Constitution Act 1982. This acknowledgement provides the legal foundation of the modern land claims process and Aboriginal self-government movement. Tecumseh's actions during the War of 1812 forced the British to concede that without the goodwill, cooperation, and military support of First Nations, a British presence in North America could not survive. Without putting too fine a point on the matter, were it not for the 
presence and participation of First Nations fighters under the direction of their own indigenous military leaders like Tecumseh or the bi-racial John Norton (Joseph Brant's own chosen successor at Grand River), waging war alongside British regulars and Canadian militia, present-day southern Ontario from Windsor eastward to at least Toronto, and possibly beyond into Quebec as far as Montreal - the economic and industrial heart of modern Canada - would quite likely be a part of the United States of America. $^{17}$

It is insufficient to attribute Aboriginal peoples' willingness to do battle on the side of Crown military forces solely to sentiments of loyalty to that Crown. Aboriginal motivations were much more complex and multi-faceted than such a simplistic interpretation would allow. Similarly, poor translations into English or French did not do justice to the rich symbolic and rhetorical language of First Nations cultures and societies, wherein complex political, legal, and economic inter-relationships with Europeans and with each other were frequently expressed in metaphors of kinship obligation and familial responsibility. It was in this manner that Queen Victoria was conceived as "the Great Mother" or "our Mother" by prairie First Nations at the time that the numbered land cession and surrender treaties were being signed across the West. This led many observers to conclude that from a certain stage Native peoples had suddenly adopted a stance of quaint or naive subservience to the person of the Monarch and her representatives on Canadian soil. This is inaccurate. Within Native political culture, alliances and treaties were envisaged as means of securing ongoing reciprocal relationships with colonial and later Dominion governments. Native people realized in signing treaty documents they were undertaking certain responsibilities and obligations 
which for generations to come would have the most profound implications for their descendants. In situating the Queen as "the Great Mother", however, it was their understanding that the sovereign was likewise agreeing to assume monumental responsibilities toward the future wellbeing and prosperity of Aboriginal populations across her Canadian dominions. In this way First Nations envisaged the treaties as living contracts or agreements, and not as individual once-and-for-all undertakings to give up their lands and sign away their rights forever. It was only during the late 19th century that Dominion and imperial officials themselves began injecting that particular adjective White into the symbolic title of "Great Mother". This reflected growing concern among Victorian-era colonial administrators during the waning days of the British Empire that notions of racial difference and superiority be somehow embedded within the relationship between the Monarchy and its indigenous allies around the globe. ${ }^{18}$

An underlying premise of this thesis research is that Canada was founded as a nation-at-arms, that the Crown viewed Aboriginals as British subjects, and that wherever the combined circumstances of geography, economy, and manpower so dictated, the Aboriginal peoples could be looked to in furnishing a portion of this defence requirement. ${ }^{19}$ This holds true as much for the Red River Métis homeguards who were mobilized in 1871 to repel anticipated Fenian raids into southern Manitoba, as it does today for the Indian, Inuit and Métis members of the Canadian Forces Ranger Patrol Groups who provide a military presence across the otherwise sparsely inhabited regions of the Canadian North and along our coastlines. ${ }^{20}$ However, whereas successive colonial or Dominion governments articulated their own specific objectives when embarking upon particular military undertakings, their "war aims" during time of actual hostilities, so too 
did particular First Nations and other Aboriginal constituencies seek to advance their own agendas for change when participating in any given conflict.

During Canada's participation overseas during the major wars of the 20th century, the individual motivations of Aboriginal service volunteers largely coincided with those of other Canadians. These included economic necessity, peer pressure, perceived opportunities for adventure, a chance to flee unsatisfactory domestic circumstances at home, etc. ${ }^{21}$ However, it must be borne in mind that in the case of Aboriginal peoples collectively, specifically status Indians, the outcomes of their participation had an aggregate effect that far outweighed the implications of their individual service: military service by status Indian people during wartime had the net effect of renewing their end of the bargain within the historic treaty relationship with the Crown, thus providing Indian people in Canada as a group with a greatly increased moral claim to more equitable treatment within Canadian society generally. As Six Nations Great War veteran and political organizer F.O. Loft observed,

As peaceable and law-abiding citizens in the past, and even in the late war, we have performed dutiful service to our King, Country and Empire, and we have the right to claim and demand more justice and fair play as a recompense. (quoted in Miller, 2000, 319).

In short, the circumstances of Aboriginal veterans in Canada had been absolutely unique, insofar as even though they and their people were actively being denied the full rights and benefits of Canadian citizenship at home, they had nevertheless been at the very forefront in fulfilling abroad what is arguably that single most onerous and profound obligation of citizenship, in donning the Sovereign's uniform, and bearing arms against the nation's enemies. 
The presence and participation of Aboriginal people in the ranks of Canadian military forces serving overseas have always been lively features of our international commitments, and something invariably commented upon by foreign observers. In short, Aboriginal people are a feature of Canada's military identity, just as they are a feature of Canada's national identity generally. This is a theme which deserves to be studied in greater detail than has thus far been the case. No nation may aspire to self-awareness without some recognition as to the means by which - and of the cost at which - that path to success and achievement was first embarked upon. The high ideals of "Peace, Order, and Good Government" notwithstanding, the necessity of self-defence made military affairs a major factor in Canada's early development.

This thesis research, then, aside from its particular subject matter, deals with the larger theme of Aboriginal peoples in Canadian military service. During the two World Wars, Métis and Inuit enlistments were never specifically recorded. Among status Indians alone (i.e. those considered to be legally "Indians" within the meaning of the federal Indian Act legislation and therefore subject to the particular record keeping requirements of the then-Indian Affairs branch), more than 4,000 volunteered for service overseas during the First World War, and more than 3,000 in the Second World War. ${ }^{22}$ They enlisted despite the fact that status Indians generally did not receive the unrestricted right to vote federally - and thus did not enjoy the full rights and entitlements of Canadian citizenship - until 1960. ${ }^{23}$

During the Rebellions of 1837-38, again during the Fenian Raids, and later yet again during the Red River Expedition, there were contingents of Aboriginal volunteers, allies and loyalists to the Crown interest, who made their services available to the legally 
constituted governing authorities for use on Canadian soil. In the late 19th and into the 20th centuries there were Aboriginal participants in the various colonial adventures in which Canadians took part during the waning days of the British Empire; for example with the Nile Expedition of 1884-85, and during the South African War. Later, when the Royal Air Force came into being on the morning of 1 April 1918 with the amalgamation of the former Royal Flying Corps and the Royal Naval Air Service, one of its first combat losses that spring day was a Canadian Indian commissioned officer (and Grand River Dehorner) serving as an artillery observer and air gunner. During the Second World War, another Native serviceman (also a Dehorner) and veteran of the Canadian Expeditionary Force and later of the RAF, attained the rank of brigadier.

Aboriginal Canadians have seen their share of service in support of Dominion, Commonwealth and British imperial military projects. By the start of the $20^{\text {th }}$ century they did not fight for traditional notions of glory or for gain, although in many communities certain vestiges of the former indigenous warrior ethos remained intact, despite other cultural shifts. The motives of those Native individuals and groups who under different circumstances cooperated with colonial authorities against other Aboriginals were varied and complex. These ranged from the desire to act against traditional enemies, to the conviction that the advent of Crown hegemony would in fact have a stabilizing influence upon inter-tribal relationships. As with non-Natives, however, certainly by the start of the $20^{\text {th }}$ century the majority of First Nations now came from communities wherein a life lived at home, at peace amongst one's family and alongside one's neighbours, was the ideal. Yet formerly, when compelled to do so, they did not hesitate to take up arms. At an earlier period in this history of Indian-white 
relations in what later became Canada, when First Nations did choose combat they were able to take to the field as organized groups of fighters under their own indigenous leadership, as full and equal allies to the Crown. By the middle of the nineteenth century, however, after their circumstances and fortunes had changed dramatically for the worse, and they had become enclaved within the ever-expanding colonies of British North America, they were for a period of time excluded from various national projects, including military service. No longer courted as military allies during wartime, nor favoured as economic partners in peace, and having by this time suffered several successive generations of continuing population decline, the Aboriginal peoples were increasingly seen as impediments to agricultural expansion, industrial development, or natural resource exploitation, and colonial governments began to covet their lands over their cooperation. Beginning in the decades following the War of 1812, official policy was that Aboriginal peoples were to be either dispersed or isolated, with any surviving remnant populations being assimilated directly into colonial society. In short, by the midnineteenth century, assimilation became the means, and the attainment of Aboriginal lands became the goal, of government Indian policy. ${ }^{24}$

When some Aboriginal communities in Upper Canada offered to form all-Native volunteer militia companies at the time of the Rebellions of 1837-38, and again during the Fenian raids of the 1860 's, colonial authorities balked. While it was recognized that groups of organized indigenous militia would be of tremendous value during time of domestic insurrection, some government authorities questioned the role to which they would revert come peacetime as the government attempted to resume its project for Aboriginal containment. ${ }^{25}$ In other words, in the space of the few decades following the 
War of 1812, colonial officials had become suspicious of Aboriginal people who tried to organize themselves militarily. Later, during the South African War, while petitions were being received by government officials from Aboriginal groups in eastern Canada seeking to form all-Native contingents for service overseas, and as individual Aboriginal persons began enlisting for the first time as private soldiers in the Dominion militia, Indian agents on the prairies - still reeling from the shock of the Northwest Resistance were expressing concerns that local bands under their charge were sympathetic to the Boer cause. ${ }^{26}$ Thus for a period of time as colonial and subsequently Dominion officials sought to complete their agenda for the assimilation of Aboriginal peoples in the decades immediately before and after Confederation, the government remained ambivalent as to the military potential and capabilities of its indigenous inhabitants. In enabling the provision of modern military training and organization for Native Canadians, how could the government be assured that one day this training and organization would not be used against the state itself? This fear would again resonate on the Grand River lands following the First World War, when newly returned Six Nations troops of that conflict all seasoned combat veterans - assumed leadership of the Dehorner movement, and demanded political change. ${ }^{27}$

In any event, by the second year of the Great War, after the initial outpouring of enthusiasm had worn off, and as the casualty lists grew ever longer and the number of recruits dwindled, there began for a period of time campaigns to recruit entire battalions of status Indians for service overseas. For various reasons, these plans were never carried through to completion, but two battalions, the $107^{\text {th }}$ Battalion Canadian Pioneers and the $114^{\text {th }}$ Battalion, saw service as the only two CEF Battalions largely manned and officered 
by Canadian Indians and Métis from across Quebec, Ontario, and the prairie provinces. Many others from the north shore of Lake Superior served with the $52^{\text {nd }}$ Battalion. $^{28}$ Dozens more, skilled loggers, millhands, and construction workers, served with various formations of the Canadian Forestry Corps and the Canadian Railway Troops. A few saw action with the flying services. ${ }^{29}$

Two especially comforting elements of Canada's national mythology involve military themes. The first of these is Canadians' perception of themselves as a fundamentally unmilitaristic and non-colonizing people who have historically taken up arms only in times of dire domestic or international emergency, and then only to confront direct threats to their own freedoms and liberties, or to those of citizens of allied nations abroad. The second is the emergence in the global arena following the Second World War of Canada in the guise of an international peacekeeper, often in support of international human rights enforcement and to facilitate the provision of humanitarian relief assistance abroad, as per the spirit of the United Nations or NATO charters. Insofar as these two views are largely true, they are indeed justifiable sources of pride to Canadians generally. However, they are tempered by the reality that Canada was largely founded as a nation at arms, as stated, and in considering the role of Aboriginal peoples in Canadian military service, some will perceive certain ironies, inconsistencies, or contradictions.

To the extent that the territorial growth and expansion of Canada historically entailed the dispossession, containment, or dispersal of regional Aboriginal populations, some will question the cost at which this expansion occurred to the detriment of Aboriginal cultures and in violation of Aboriginal land rights. It should be borne in mind 
that the British Crown itself, through that imperial edict of George III known as the Royal Proclamation of 1763, acknowledged Aboriginal title and described a formal process by which Crown representatives were to treat with Aboriginal owners in obtaining cessions or surrenders of their lands. This being the case, certain questions come immediately to the fore in considering the participation of Aboriginal peoples in Canadian military endeavours. Why, for instance, did Indian, Inuit, and Métis Canadians volunteer for service at all during the two World Wars? At what point historically did they apparently come to perceive the political and other aspirations of mainstream Canadian society as coinciding with their own? After all, those Natives from eastern Canada who in the previous century formed the backbone of the Red River Voyageur Contingent in 1870 were engaged in an undertaking whose ultimate objective was the suppression by armed force of another Aboriginal (i.e. Métis) insurrection and rejection of Dominion authority. Yet a year later, these same Métis whom the Voyageurs had been sent to quell were being relied upon by Dominion officials to provide the nucleus of a local militia which would repel an anticipated Fenian invasion. ${ }^{30}$

So historically have Aboriginal peoples' motivations in volunteering for military service been any different from other Canadians? If so, in what ways? What were they hoping to achieve? What other options did they have? What did they lose in so doing? All these questions take on particular resonance when considering the wartime and postwar actions of those 300-odd Six Nations band members who volunteered for service with the CEF and other Allied armies during the First World War, against the wishes of the traditional council of Confederacy Chiefs, and who upon their return home demanded that the Dominion government intervene on their side, to force political change. 
It is important to note that under the Royal Proclamation of 1763 , Aboriginal title could only be surrendered to the Crown and not to private individuals or commercial interests; that is to say, Aboriginal lands could only be transferred from one sovereignty to another. Devastating in its implications toward Aboriginal rights, however, was the Proclamation's underlying principle of the extinguishment of Aboriginal sovereignty upon the transfer of lands to the Crown: from that point onward, Aboriginal residents might enjoy a continued right of occupancy and use of portions of the lands so surrendered, but in the eyes of the Crown - and under the law of nations - the original Aboriginal sovereignty was forever extinguished. As lawyer and independent scholar John S. Hagopian has shown, despite the expansive and overly generous interpretation provided the Royal Proclamation by other commentators, the Royal Proclamation stipulated that Indians could continue occupying surrendered lands but never own any, and that in all circumstances the Crown held the paramount and underlying title. ${ }^{31}$ L.C. Green likewise interprets the Royal Proclamation in limited fashion, finding that the Proclamation was an act of royal largesse intended to facilitate the orderly expansion of British sovereignty westward across the North American landmass while concomitantly extinguishing Indian title, and that any remaining Indian rights of occupancy (which continued to exist only at the pleasure of the Crown) certainly did not amount to sovereignty. ${ }^{32}$

Following the War of 1812, with the resolution across North America of successive power struggles between various imperial regimes and their successor states, with a lessening (but not disappearance) of border tensions between the British colonies and the United States via the Rush-Bagot Convention of 1817, with the diminishment of 
the fur trade as a foundation of the North American economy, and with enormous Aboriginal population declines occurring simultaneously with exponential increases in the rate of European immigration, the support of First Nations across eastern and central North America was no longer required by the British Crown in various endeavours as it once had been, whether in economic or military terms. In effect, First Nations had ceased being regarded as potential military allies during war, nor as trading partners in peace, and increasingly were seen as economic liabilities and as impediments to colonial growth and expansion. Significantly, in 1830 the administration of Indian affairs in the Canadas passed definitively from military control to civilian jurisdiction.

The initial periods of interaction between the Aboriginal nations and the first European newcomers may be characterized in terms approaching relative equality. Across the northeastern and Maritime regions the nature of these earliest relationships was reflected in the treaties of "peace and friendship" entered into between the various First Nations and their French and English counterparts. Briefly, in times of peace the assistance of First Nations was actively sought by Europeans in pursuit of particular economic endeavours, principally the fur trade, the success of which was dependant upon the participation and cooperation of Native peoples. In times of war, assurances of Native military support, or at least guarantees of neutrality, became the goal of European negotiations. Issues of land cession and surrender by Aboriginal nations to European governments were typically not features of the peace and friendship treaties. However, by the mid-nineteenth century, the assimilation of Aboriginal populations, entailing their Christian religious conversion and the elimination of distinctive indigenous cultural practices, and the attainment of First Nations lands, had become the objective of colonial 
and subsequently Dominion Indian policy. In a departure from the former practice of negotiating peace and friendship treaties, a new policy of concluding land cession and surrender treaties was initiated. This new policy approach was formalized as early as 1850 in present-day Ontario with the negotiation that year of the Robinson-Huron and Robinson-Superior treaties. The process was resumed west of the Great Lakes in 1871, and from then through 1921, numbered treaties 1 to 11 were concluded across the present-day prairie provinces and much of the Yukon and NWT. The treaties typically provided for the cession and surrender of First Nations traditional territories and hunting grounds to the Crown, in exchange for promises of reserved lands and the payment to First Nations of certain compensation including cash, either in lump sums or as annuities. Wherever possible, subsistence level agriculture was to be promoted as the new means of livelihood, in replacement of previous cultural patterns based upon the hunt, fishing, trapping, and some horticulture. Accordingly, aside from cash payments, provisions were also made in many instances for the granting of annual supplies of seed, livestock, feed, and a limited range of farming implements and other equipment. The former provision of annual supplies of firearms and ammunition was reduced correspondingly.

The notion of a legal "Indian status" had been first introduced in Lower Canada (Canada East) in 1850, with the passage that year of An Act for the Better Protection of the Lands and Property of the Indians in Lower Canada. This Act provided the first legal definition of who was to be considered an Indian from the perspective of government, for the purposes of the administration of Indian affairs. The definition contained in the 1850 legislation was in fact relatively liberal, in the sense that it recognized as Indians not only all such persons who were obviously racially Aboriginal, but also non-Indians who had 
married into Indian communities or who were otherwise accepted by First Nations themselves as community members on the basis of their own Aboriginal customary law traditions. This included non-Natives who had been adopted as infants, children, or adults into Indian communities. Definitions of Indian status and qualifications for registration in band membership appearing in subsequent legislation were more exclusive, as later governments became increasingly concerned with paring down rather than increasing the number of persons who might be eligible to receive treaty payments, rations, and other entitlements. Another key piece of legislation during this era was the Gradual Civilization Act of 1857, the final imperial legislation pertaining to Indian policy before such responsibility devolved to the respective colonies and provinces in 1860 . It became the basis for the Dominion's first consolidated Indian Act in 1876, and was the first legislation to limit Indian access to the franchise while establishing formal Indian status as a legal category under government control. ${ }^{33}$

As early as 1869, with the passage of An Act for the Gradual Enfranchisement of Indians, legislative mechanisms were introduced which provided for the mandatory loss of legal Indian status by Indian women marrying non-Indian status men. Such provisions were to remain in force through all subsequent Indian Act amendments, from its consolidation as federal legislation in 1876, until the passage of Bill C-31 in 1985.

With the coming of Confederation in 1867, section 91(24) of the British North America Act imparted exclusive jurisdiction over "Indians and Lands Reserved for Indians" to the federal level of government. This federal responsibility for the administration of Indian affairs was codified in 1876 with the passage that year of the first consolidated Indian Act. Prior to this time separate pieces of legislation in the 
respective colonies or provinces provided a policy and legislative framework for the administration of Indian Affairs. With the passage of the Indian Act of 1876, the entire spectrum of a national Indian policy was brought under one cover. Through the Act, an entire category of the Canadian population had its dealings with governmental authority unilaterally delegated to a single level of government, and within that, to a single departmental interest.

It has been within the context of this complex and shifting political, legal, economic and social background that Aboriginal participation in Canadian military service - including participation in the Great War by Grand River band members and their subsequent adoption of Dehorner ideology - and the rise of the ideology of Native grievance, have occurred. It was also within this context that the Six Nations under Joseph Brant were compensated with the grant of the original Grand River tract following loss of their traditional homeland during the American Revolution. For the purposes of this thesis research it is important to note that in dealing with such important matters over the span of several decades from the time of the Revolution until Brant's death in 1807, the Crown choose to deal with Brant, a non-hereditary leader within Six Nations culture, and John Norton, his hand-picked successor. It is notable that the Confederacy Chiefs, if unsatisfied with Brant's approach, did nothing significant to remove him from the scene, nor to reassert the authority of traditional leadership.

Six Nations claims to sovereignty of any kind were extinguished at the moment their leadership accepted a land grant from the Crown. If this was done under Brant, a non-hereditary and non-appointed leader within the Iroquois Confederacy customary law tradition, then the upholders of that indigenous Confederacy legal tradition were 
negligent in failing to intervene at that moment to repudiate and nullify his actions. Such stresses and conflicts between traditional and non-traditional forms of leadership inside Grand River culture were apparent from the time of the settling of the Grand River tract in 1784 .

To the extent that the federal Indian Act, it sundry pre-Confederation precursors, and its numerous revisions and amendments over time exemplify in the consciousness of the Canadian public, the Aboriginal population at large, and in the view of many scholars, the epitome of governmental subjugation and intrusion into the lives of status Indian peoples, it too must be placed in context. Historian P. Whitney Lackenbauer has noted how contemporary research has focused on the coercion implicit within the government's application of the Indian Act and related policy, and how the writings of Indian Affairs Branch administrator Duncan Campbell Scott are routinely used to bolster this interpretation of draconian authority. Still, government policy does not always equate to the practices actually followed, and for their part Indian persons and groups had a variety of strategies open to them in accommodating or rejecting Indian policy, and otherwise mitigating its effects. ${ }^{34}$

Thus, while the legislative intention of the Indian Act may have been to assert governmental control and authority over virtually every aspect of Indian life, both at the collective and individual level, it may also be read as an overly ambitious, pompous, and self-important piece of legislation, with delusions of grandeur, reflecting Victorian and Edwardian era values and prejudices, and the aspirations of the minor civil servants and career bureaucrats who drafted and tabled its successive revisions over time. In actuality, Indian policy began and remained a relatively minor consideration of the new Dominion 
government, and it lacked status as an important priority of state by those who truly held the reins of political and administrative power in the country. ${ }^{35}$ Always under-staffed and under-funded in the tiny civil branch and the loose network of regional Indian Agents charged with its implementation, the Act and various other aspects of Indian policy were never consistently nor rigourously applied. ${ }^{36}$ A notorious "pass system", never formally part of the Indian Act, was hastily introduced in 1885 at the height of the Northwest Resistance amid fears that a generalized Indian insurgency in support of the Métis was likely. However, as the pass system had no basis in law, the Mounted Police refused to enforce it after $1892 .{ }^{37}$ The potlatch ban appearing in successive Indian Acts from 1884 through 1951 was infamously applied in the Kwakiutl settlement of Alert Bay during the 1920 's, but only after staunch Anglican families in that community insisted that it be applied against competing non-Christian families who persisted in its observance as a basis for the selection of political leadership. ${ }^{38}$

A major power attributed to the Act was its denial of the franchise to status Indians. In the past, status Indians were indeed viewed as legal minors and as wards of the state. Prior to the extension of the federal franchise to status Indians without exception in 1960, status Indians generally speaking could only exercise the federal voting franchise through surrendering their legal Indian status via the process of enfranchisement. It should be noted, however, that from the inception of Upper Canada in 1791 until the Gradual Civilization Act of 1857, status Indian males in central Canada, so long as they met the legal property qualification which applied to all British subjects resident in the colony, did indeed have the right to vote. ${ }^{39}$ It was this circumstance which enabled John Brant, son of Joseph Brant, to be duly elected to the Upper Canadian House 
of Assembly in 1830. Following this, during a period from 1857 until modified enfranchisement provisions appeared in the first federal Indian Act in 1876, only one Indian male was ever actually enfranchised under these conditions. ${ }^{40}$ The federal franchise was briefly held by status Indian males in specified constituencies from 1885 through the provisions of the Macdonald Franchise, until this was removed by the Liberals in $1898 .^{41}$ Additionally, the Military Voters Act of 1917 extended the federal vote to status Indian volunteers serving in the CEF and Allied forces, while concomitantly the War-Time Elections Act extended the vote to their immediate female relatives (wives, widows, mothers, sisters and daughters). ${ }^{42}$ For clarity, the Dominion Elections Act of 1924 confirmed that status Indian veterans of the Great War, including those resident on reserves, retained the federal franchise to vote in their respective ridings. ${ }^{43}$ While it is not possible to determine how many eligible status Indians actually exercised their right to vote under these conditions, it is inaccurate to state categorically that all Indians at all times were without the vote until 1960.

Then, as now, the Indian Act contained a mosaic of restrictions and prohibitions which were hastily and arbitrarily introduced to address temporary local circumstances and changing situations. In practice many of its shifting range of provisions were never actually applied against anyone before suddenly disappearing into subsequent amendments. Thus, while a body of anecdotal evidence in the form of oral histories from aggrieved Aboriginal descendants today may attest to the impact of especially draconian provisions against ancestors, historical researchers frequently encounter difficulties in uncovering documentary proof that any such provisions were ever actually applied against identifiable Indian persons. For example, there is no documentary evidence that 
any named Indian person ever lost their legal Indian status for enlisting in any branch of the Canadian military during wartime or for accepting an officer's commission, despite such assertions in journalistic essays and popular histories appearing today. In short, the Indian Act remains a paper tiger, more notorious by reputation than by actual effect. Certainly as regards the specific subject matter of this thesis, none of the nearly 300 persons from Grand River who attested for service with the CEF or Allied armies during the Great War lost their legal Indian status as a result, nor did any of the handful who joined as officers or who were later commissioned in the field. ${ }^{44}$

This chapter has provided an overview of Aboriginal-white legal, political, economic and military relations, from the era of the Royal Proclamation of 1763 until the outbreak of the Great War in 1914. It has also provided a brief history of the specific Indian legislation and policy which affected Grand River band members in that era. Aside from the Royal Proclamation itself, these included the Haldimand Deed, the Simcoe Patent, pre-Confederation legislation and policy pertaining to the administration of Indian affairs, and finally the first consolidated Indian Act following Confederation. It has discussed the implications of the Royal Proclamation for the extinguishment of Aboriginal sovereignty, and has shown that while the Indian Act had a wide ranging legislative purview, its provisions were not consistently applied. It has demonstrated that strategies were available to those Grand River band members who by the eve of the Great War might choose to cooperate with, or challenge, the authority of both the Dominion government and the Confederacy Chiefs, thus setting the stage for later political activism by returning Six Nations following the war. 


\section{Chapter 2: Six Nations Governance and the Rise of the Dehorners}

This chapter will chart the rise of the dissident reform movement called the Dehorners. It will detail specific grievances pertaining to loss of land, and the lack of political voice for those Grand River band members who, by virtue of their tribal affiliation, were excluded from the traditional constitutional system, the Great Law. It will further show how, when it suited their purposes to do so, Six Nations band members could actually demand the application of selected Indian Act provisions within their reserve community, thus demonstrating that traditional authority at the Six Nations of the Grand River was not immune to challenge from within. The previous chapter has demonstrated that while the Indian Act and its precursors attempted to provide a comprehensive legislative framework that might govern the conduct of Indians in the Dominion at both the individual and collective level, it was incapable of doing so given the paucity of resources available to those charged with implementing it. Additionally, where band members chose to ignore its various restrictions, they were able to do so with impunity. The present chapter will now show how the Indian Act could be selectively rejected or invoked to support a competing political agenda.

From the time of its founding in 1784, the Grand River community assumed a status that was and remains unique across all of Iroquois history and culture. It remains the only enclave in which elements of all Six Nations are represented (Seneca, Cayuga, Onondaga, Oneida, Mohawk and Tuscarora). It also includes descendants of other smaller non-Six Nations groups. Also from the time of its founding until the major political change which occurred in 1924 (and notwithstanding the role as spokesman to the Crown ascribed by the British to the non-hereditary leader Joseph Brant) its residents 
were governed internally by a Six Nations Council of Confederacy Chiefs, according to principles and procedures articulated in the Kayanerenhkowa (the Great Law or the Great Peace), which incorporates both the origin narrative and oral constitution of the original Five Nations Confederacy of Iroquois. The definitive English-language rendering of the Great Law remains that account compiled and edited by Chief John Arthur Gibson, and published by Duncan Campbell Scott in the Transactions of the Royal Society of Canada in 1911. Entitled The Traditional History of the Confederacy of the Six Nations, it was also more informally called "The Chiefs" Version" of the Great Law, since it was compiled and published under the authority of a specially struck committee of the Confederacy Chiefs.

Very briefly, the Great Law allows for the appointment of 50 hereditary male chieftanships overall, based upon the clan affiliation of representatives from the various national groups comprising the five original nations. Accordingly, the Onondaga have 14 chiefs, the Seneca 8, the Mohawk 9, the Oneida 9, and the Cayuga 10. The Tuscarora had joined the Confederacy by 1720 , thus creating the Six Nations proper. Like other dependent groups at Grand River, however, such as the Delaware, Tutelo, and Nanticoke, the Tuscarora had limited say and representation within the Confederacy Council, beyond matters relating directly to their own members. As pioneering ethnographer Lewis Henry Morgan described in his seminal work League of the Ho-de-no-sau-nee, or Iroquois,

At the institution of the League, fifty permanent sachemships were created, with appropriate names; and in the sachems who held these titles were vested the supreme powers of the confederacy. To secure order in the succession, and to determine the individuals entitled, the sachemships were made hereditary under limited and peculiar laws of descent ... It thus appears that the government of the Iroquois was an oligarchy, in the literal sense, "the rule of the few;" and, while more system is observable in this than the oligarchies of antiquity, it seems, also, 
better calculated, in its framework, to resist political changes. (Morgan, 1851, 6263).

Further,

The unchangeable number of the rulers, and the stability of the tenure by which the office itself is held, are both sources of security in an oligarchy. To the former safeguard the Iroquois adhered so firmly, that upon the admission of the Tuscaroras, as the sixth nation of the League, they were unwilling to increase the original number of sachemships; and the Tuscaroras have not to this day a sachem who is admitted to all the privileges of a sachem of the Confederacy. (Ibid, 102103).

In other words, the Great Law had no amending formula to provide new member nations with full political voice, once admitted to the Confederacy. In addition to Morgan's League, two other classic accounts of the structure of the Confederacy and the operation of its Great Law in its model form are to be found in his Houses and House-Life of the American Aborigines (1881), and in the largely derivative account of Iroquois federal government appearing in Friedrich Engels' The Origin of the Family, Private Property and the State (1884).

Vacancies for chieftanships were filled at the recommendation of clanmothers, acting on behalf of each clan within each nation. On a limited basis, other adult males could be delegated as non-hereditary "pine tree chiefs" with limited authority, usually in recognition of their oratorical skills and knowledge of Confederacy lore and protocol. However grand in concept and design, in its practical implementation such a system was prone to duplication and administrative inefficiency. Surviving records from Grand River throughout the $19^{\text {th }}$ century indicate that the number of claimants for the 50 hereditary chieftanships available varied between 57 recorded in 1847, to 62 in 1899, with a high of 76 recorded in $1895 .{ }^{45}$ Thus the Six Nations Confederacy of Iroquois, and its undeniably 
impressive origin narrative and oral constitution manifested in the Great Law, existed more as an ideal type than as a workable system of federal or even municipal government.

From the 1790's into the 1840's the original extent of the Grand River Tract (six miles deep along either bank of the Grand River from its mouth to its source) was dramatically reduced as the Chiefs, or Crown officials or other Indians claiming to be acting with the Chiefs' permission, took it upon themselves to transfer lands to nonNative ownership. During the 1830 's and 1840's in particular there were major land transactions and failed business investments using band funds which eroded the land base even further. These included investment in the failed Grand River Navigation Company from 1834 to 1844 , the transfer of the Caledonia town plot in 1841, and land transfers to the New England Company in 1847-48.

Another ill-considered series of transactions with the New England Company concerning plots of land on the outskirts of Brantford, known collectively as the Burtch Tract, was finalized during 1847-48, an 1845 decision of the Confederacy Council agreeing to do so providing the requisite legal sanction of the deals. ${ }^{46}$ Other extensive plots surrounding Brantford and adjoining the Grand River - including those lands later comprising the original Caledonia town plot, and which today are the subject of the continuing disputes in and around Caledonia - were surrendered by a coalition of Chiefs claiming to be acting on behalf of the entire Council, to the Crown in 1841, with the understanding that government would sell the lands in question to private developers, so long as a portion of the monies so acquired reverted back to Council. ${ }^{47}$ The reserve had assumed what remain its present boundaries by 1847 . All of these land transactions and 
failed business ventures had occurred while the reserve was under the nominal management and jurisdiction of the Six Nations Council of Confederacy Chiefs. ${ }^{48}$

As a consequence of myriad such land deals having gone wrong, and Confederacy Council's seeming inability to track down and force payment of delinquent accounts, by 1861 an organized reform movement had emerged on the reserve among a minority of Six Nations band members themselves, calling for nothing less than the replacement of the Confederacy Chiefs by an elected band council system. Their first petition, organized and circulated by Mohawk Isaac Powless, garnered 167 signatures. It is significant that three of those signing were themselves chiefs within Council, indicating that this body itself was not entirely incapable of change, and that at least a small portion of the chiefs themselves was inclined toward reform. ${ }^{49}$

Over time, conciliatory elements within Council introduced limited reforms in an attempt to address certain Dehorner grievances. Initially, this took the form of appointing selected Dehorners as pine tree chiefs, thus incorporating them within the Confederacy system in accordance with traditional protocols and procedures articulated in the Great Law. As the nineteenth century progressed, as the reserve's population grew, and as it assumed much the same infrastructure as surrounding non-Native municipalities, selected Dehorners were appointed to the growing number of offices, boards, and committees administered by Council. ${ }^{50}$ These included the salaried positions of pathmaster (to oversee road maintenance), poundkeepers (to impound stray animals and escaped livestock), forest bailiffs (to guard against illicit timber cutting, and forest fires), a recording secretary (to take minutes of council meetings and other deliberations), a government interpreter (to translate between English and the numerous dialects spoken at 
Six Nations), and the prestigious position of speaker of the council. Various administrative boards and committees to which Dehorners were frequently named as members included school trustees, the board of health, the locating line committee (to oversee official surveys of reserve lands), a disputes committee (i.e. the local administrative tribunal and small claims court), and a distributing committee (to oversee the proper distribution of per diem payments to chiefs attending council meetings). ${ }^{51}$ Other accommodations were exceptional, and as leading Dehorner (and Six Nations' most distinguished soldier) Brigadier O.M. Martin would testify following the Second World War, immediately before the First World War he and James Moses, another Dehorner (later killed in action) were actually selected by the Confederacy Chiefs to be sent to Upper Canada College and the University of Toronto Law School, to train as lawyers on behalf of the Six Nations Council. Departmental inertia and the outbreak of the Great War, however, prevented these plans from coming to fruition. ${ }^{52}$

Many of the people at the forefront of this Dehorner reform movement were nonFive Nations band members, including Christianized Tuscaroras and Delawares. These, for the most part, were increasingly prosperous farmers and small business owners who, under the organizational structure of the traditional system, had little likelihood of wielding substantive political influence within Council. ${ }^{53}$ Insofar as their reform efforts were metaphorically aimed at removing the deer antler headdresses or "horns" which distinguished the headgear of hereditary chiefs, these reform activists came to be called the Dehorner Party. Other terms used from the 1860 's to the 1920 's were the Six Nations Indian Rights Association, and the Six Nations Warriors Association. The term "Warrior" in the Grand River context during this time period referred specifically to any able- 
bodied man who was not associated with a family lineage within which a hereditary title was vested. In brief, these were some of the more acculturated and prosperous farming families on the reserve, Protestant, often mixed-race, who were literate in English, and who had little or no likelihood of assuming political leadership within the traditional system. They felt that in view of its poor record in business investments and land transactions, and through acts of omission or commission which were detrimental to the collective interest, the council of traditional Confederacy Chiefs, which was highly conservative and insular in outlook, had to be deposed for the greater good and future prospects of the community as a whole.

By the second half of the nineteenth century, the reserve population thus included two major groups: one oriented toward Christian (Protestant) religious affiliation, which supported a democratically inspired but non-traditional form of government; and the other with a more traditional Iroquoian Longhouse outlook, which supported the hereditary form of leadership. Allegiances between the groups were fluid, however, and depending upon the issues at hand, individual persons might espouse support for the stance of the Confederacy Chiefs on some matters, while supporting the Dehorners on others. Christian religious affiliation, moreover, did not automatically equate to support for the Dehorner movement. For example, another influential group, emerging in 1922, was the Mohawk Workers Party, composed of members who were Anglican in terms of their religious affiliation, but who were staunch supporters of the Confederacy Chiefs in terms of their politics. Thus from the 1860 's to the 1920 's, a sometimes bewildering plethora of petitions and counter-petitions, and delegations and counter-delegations, is evident, as respective supporters of the hereditary Confederacy Chiefs, or the Dehorners, 
or the Mohawk Workers, present their claims and counter-claims before government. In some instances these are directed to the Superintendent-General of Indian Affairs, in others, to the Governor General. In yet other instances, these would be sent directly to the British sovereign at Buckingham Palace, or, after the First World War, to the League of Nations, and the International Court of Justice at Geneva and the Hague.

The context for the first Dehorner petition of 1861 was the Gradual Civilization Act of 1857 , and the subsequent devolution of responsibility for the administration of Indian affairs from imperial to colonial authority in 1860 . Additionally, 1861 was the year in which the ill-fated Grand River Navigation Company finally went bankrupt, with the Confederacy Chiefs (and thus the Six Nations community) losing their substantial investment which had bought them three-quarters ownership of the entire enterprise. ${ }^{54}$ With the transfer of Indian policy from overseas control to domestic jurisdiction, concomitant with the disastrous outcome of the Grand River Navigation Co. fiasco, the Dehorners perceived an auspicious time to act in bringing their grievances forward before a presumably more accessible colonial authority.

The text of the original Dehorner petition of 1861 reads,

To the Honorable P.M. Vankoughnet, Chief Superintendent of Indian Affairs.

The petition of the undersigned portion of the Six Nations Indians residing on the Reserve in the Townships of Tuscarora and Oneida in the Province of Canada.

Humbly sheweth:

That for some years past we have become dissatisfied with the manner in which Indian affairs have been managed, and since our Great Mother Queen Victoria has seen fit to transfer the same to the control and management of the Government of this Province, in whom we have every confidence, we think that this is the proper time to make our grievances known with a view to their redress. Our affairs as you are aware are governed by our Chiefs in Council, under the Superintendence of a Commissioner appointed by Government, these are not chosen by us, but are hereditary and hold their seats in the Council by virtue of the old customs and 
traditions of our different tribes, in general they are uneducated and are therefore taken advantage of by their white brethren, they are attached to their old customs and habits, and averse to any change, thus rendering them and the system totally unfit to forward our civilization and to bring out the energies of the people.

We believe that from the time we surrendered a great portion of our lands to be settled, our people have not improved but rather retrograded and our race by the bad habits contracted from the white people are by degrees becoming extinct, we think it therefore high time that a remedy should be applied, and as comparatively speaking many of our people are as well educated as the majority of the whites, and as well fitted to govern and regulate our internal affairs as they are. We therefore being desirous of putting an end to this state of things, and becoming more civilized so as to improve the moral and social condition of our people, pray that your Government may take our affairs into your serious consideration, and pass an Act at the next sessions of the Parliament of this Province abolishing the government of the Chiefs, and granting us power to regulate our own internal affairs, and to elect our own rulers, of course always subject to the Superintendence of a commissioner or commissioners appointed by the Government as heretofore. (167 signatures) (quoted in Weaver, 1975, 122-123).

This petition articulates the platform of the entire Dehorner movement over succeeding decades and in essence provides its charter. It expresses two grievances in particular relative to Confederacy rule which appear in subsequent reform petitions: the Chiefs are poorly educated by colonial standards, leaving them open to exploitation by unscrupulous whites, and they are too conservative and wedded to tradition. Conversely they present themselves as educated, ambitious, and progressive, and hold the colonial government responsible for implementing substantive change within internal Grand River politics. Notwithstanding the Gradual Civilization Act of 1857, however, at this stage no legislation existed which provided government a mandate to introduce either elected band councils on Indian lands, nor municipal-style government of the kind which the petition was in effect advocating. ${ }^{55}$ An official memorandum concerning this petition simply responded in part, 
With regard to the suggestion offered ... that Municipal Institutions should be brought into existence among the Grand River Indians ... the Provincial Government has not when the subject has been mooted been prepared to take up the subject. (Weaver, 1975, 134).

An 1880 amendment to the first consolidated Indian Act of 1876 expanded the powers of the Dominion government to intervene in internal band politics and traditional self-government on Indian reserves, and to impose democratic governance by elected band councils. ${ }^{56}$ A separate Indian Advancement Act in 1884 further enhanced the potential for federal intervention by authorizing the Dominion to remove traditional leaders considered incompetent to exercise their duties. ${ }^{57}$ These features of the 1884 Act were subsequently adopted into a wholly revised Indian Act in 1906. An 1894 Dehorner petition to the federal government bearing 212 signatures or approximately $20 \%$ of Six Nations' adult males was met with the response that there was no need for Indian Department interference in internal Grand River politics because the Confederacy Chiefs continued to govern to the government's satisfaction. ${ }^{58}$ By 1907 a rejuvenated Dehorner movement was organized under the title of the Indian Rights Association and on 15 March that year submitted this petition,

The petition of the undersigned chiefs, warriors and members of the Six Nations Indians, residing on the Grand River Reservation, humbly sheweth:-

(1) That the system of committing the Government of the Six Nations Indians to a Council of hereditary life chiefs, is detrimental to the advancement of the Nation for the following among other reasons, -

(a) The present Council, a majority of whose members are uneducated men, is incompetent to guide a people who are progressive and prepared for still further advancement in civilization.

(b) Under the present system of Government no encouragement is extended to young men to devote their energies and talents for the good of the nation.

(c) The present Council is not a representative one, as the people have no voice in its selection, nor are its members chosen on account of their fitness or ability. 
The people, therefore, have no voice or share in the management of their own affairs nor in the expenditure of their own money.

(d) The present number of Chiefs is too large and involves too great an expenditure of money in the meetings of the Council.

(2) Your petitioners therefore think that an elective council would tend greatly to promote the general advancement of our people.

(3) Your petitioners therefore humbly request, that you would submit this petition to the Governor in Council and obtain possible the introduction of a system of election of chiefs [for the] nation as provided for in the $75^{\text {th }}$ section of the Indian Act. (300 signatures) (Weaver, 1975, 326-327).

The official response to this petition vaguely stated that if a majority of the Six Nations bands' adult males voted in favour of such a change, then the Department might be inclined to intervene accordingly. As it was, the 300 signatures appended to the petition accounted for no more than $25 \%$ of the reserve's adult male population, and thus government was not in a position to intervene. ${ }^{59}$ The Confederacy Chiefs and their supporters, meanwhile, were equally active in presenting their claims and grievances before government. A portion of their response to the 1907 Dehorners' petition states their opinion of the Dehorners and Dehorner motivations concisely,

[T] he Indian Rights Association [i.e. the Dehorners] is composed of about a half dozen men who desire to become councillors, and they have a few followers who represent the unthrifty and ne'er do well amongst our people. Some of these had property and sold it and spent the money, now their leaders promise them that by an elective system of Councillors ... the lands would be divided and they would again come in for a share ... They are mostly half breeds one eighth, and one sixteenth Indian ... That is very nearly all white ... Lieutenant Governor Simcoe gave this land to the Chiefs warriors and women of the Six Nations to be enjoyed by them forever ...there is nothing said in this deed about a one eighth or a one sixteenth Indian ... the former should not be on the [band] list at all ... You may imagine the indignity which a chief feels when some good for nothing fellow, some worthless fellow, who perhaps should not be on the list at all profers an untenable charge against him. (Ibid, 332-333). 
The final prewar Dehorner petition of 1910 carried the same wording as the 1907 petition, and again apparently garnered 300 signatures. ${ }^{60}$ This time in response, government officials stated,

[I]n a matter of such importance as the radical change referred to, it is necessary for the Department to go slowly, and the Minister has decided that he will not sanction the change until it shall have been shown that there is a substantial and permanent majority, say 66 and 2/3 in favour of the same. (Ibid, 348).

Thus from 1861 there had existed a grassroots movement within Six Nations itself to introduce political change in favour of elected band councils. From 1880 formal Dominion legislation existed to facilitate this, however, no such action was acceded to by the federal government. Whether forthcoming from reformers within the Dehorner movement, or from the Confederacy Chiefs, clanmothers, and their respective supporters, what emerges from the government response relative to such petitions is an apparent reluctance on the part of colonial or Dominion officials to intervene to remove or limit Confederacy rule at Grand River. In other words, prior to the First World War there is no evidence over time of any governmental initiative or agenda to terminate traditional government at Six Nations. On the contrary, it is the Dehorners who are told on successive occasions that in the absence of demonstrable proof that their calls for reform enjoy majority if not unanimous support across the spectrum of Six Nations band membership, their calls for significant change could not be acceded to. Indeed, the initial government response to the 1861 Powless petition was that there were no provisions within any existing Indian legislation at that time which empowered such governmental intrusion upon internal band politics. A later response to the 1910 Dehorner petition stated that a clear indication of a minimum $2 / 3$ of the Reserve's population supporting 
such an initiative would be required before government might consider intervening.

Following 1910, the Dehorners were apparently given the understanding that their platform would require unanimous support from all Six Nations band members before government could consider involving itself in the internal politics of the Six Nations of the Grand River.

Writing many years after the fact, Dehorner Elliott Moses, at one time a leader in the movement and later its unofficial historian, recalled the matter of the requisite number in the following terms,

For a number of years the government paid little or no attention to this new movement [i.e. the Dehorners], however, this association were [sic] convinced that they were supporting a worthy movement and continued to press for a hearing with the result that the government stated that if it could be shown that a majority [underlining added] of the people were in favour of the suggested change consideration would be given to the matter. The association intensified their campaign by holding meetings in public places and private homes and were finally able to show that two thirds [underlining added] of the people were in favour of the change. On the strength of this information the government gave due consideration to their efforts and finally advised that it would be necessary to show a unanimous vote [underlining added] of all the people before further consideration would be given their request, the decision being based on the historic record of the old council having served its people well for so many years. This decision was most discouraging to the supporters of the elective system of council for it was evident that a unanimous vote of the people was an impossibility. This discouraging report came just previous to the outbreak of world war one with the result that the association made no further effort to promote their cause during the war years. (Moses, 1975, 2-3).

Moses' claim that the Dehorners were in fact finally able to demonstrate support of $2 / 3$ of the reserve's population for their cause must be read with caution. None of the petitions examined for this thesis research support this. As indicated above, the 300 signatures appended to the 1907 Dehorner petition represented perhaps $25 \%$ of the reserve's adult male population at the time. 
In conclusion, this chapter has provided a brief overview of the origins of the Six Nations of the Grand River and has demonstrated that virtually from the time of its founding, traditional authority at the Six Nations of the Grand River was being challenged from within. Despite the designation of this enclave as the Six Nations of the Grand River territory, there were in fact more than a dozen bands present, including nonIroquoians like the Delaware, Tutelo, and Nanticoke. These had limited say within traditional government under the Great Law, yet had grown ambitious in view of their success in farming and small business endeavours. Each of these factors was conducive to the emergence of dissidents like the Dehorners. By the start of the twentieth century it appears evident that negative perceptions and suspicions were present on all sides: the Dehorners saw the Confederacy Chiefs as tradition-bound incompetents; while the Dehorners were perceived by the Confederacy Chiefs as a sinister organization composed of mixed-bloods seeking material gain. The government in turn seemed disinclined to involve itself in internal Grand River politics, beyond questioning the amount of grassroots support which the Dehorners actually enjoyed amongst the Six Nations band membership as a whole. 


\section{Chapter 3: Six Nations of the Grand River in the First World War}

Aboriginal support for Canadian military involvement during the Great War, as extensive as it ultimately was, was by no means universal. The cultural, political, legal, and economic pressures for Native peoples to participate, or not participate, were intense. Before the War ended, these had served to divide communities and families. Some maintained that prior treaties or other agreements with the Crown, combined with the force and effect of the federal Indian Act legislation of that era, effectively exempted their band members from any legal or moral liability for military service. Others felt that their participation in the war effort would enhance their claims toward full citizenship and legal equality in Canada come peacetime.

It is facile to dismiss the involvement of those Native persons who across time and place, in some larger undertaking, chose to cooperate with government officials in the attainment of some goal, as merely the actions of those unfortunates functioning with an assimilated psyche, the anomalous perpetrator-victims of a self-inflicted internal colonialism. Such assertions are tautologies which cannot be proved or disproved, and are more revealing of the biases and mindset of those making the allegations. ${ }^{61}$ As this chapter will show, at the Six Nations of the Grand River, the issue of involvement or noninvolvement in the Dominion war effort brought preexisting tensions between traditional leadership and dissident groups to a breaking point. ${ }^{62}$

Wartime responses by Six Nations individuals and interest groups during 19141918 must be considered within the context of the preexisting tradition of Grand River military service on behalf of the Crown. A foundational element of the Six Nations' national identity and mythology had been their status as allies to the Crown in North 
America during the Seven Years' War and the American Revolution. ${ }^{63}$ Indeed it was the decision to support the Crown during the latter conflict that resulted in the Iroquois diaspora and the subsequent relocation of the largest single body of them to the Grand River tract, as per the terms of the Haldimand Deed. Following the settlement at Grand River from 1784, during the War of 1812, the Rebellions of 1837-38, and again during the Fenian incursion at Ridgeway in 1866, later generations of Six Nations fighters would step forward to offer their services in support of the continuity of Crown government. As the previous chapter has shown, by the eve of the Great War the respective positions and ideologies of both Confederacy and Dehorner supporters had become entrenched. Their respective responses to the Dominion effort during the Great War would have profound implications for the continuity of Confederacy government following the conflict.

Among Native groups which did participate in the Canadian war effort, the service records of many individuals and communities were distinguished. ${ }^{64}$ The Great War service record of the Six Nations of the Grand River is notable. Out of a total reserve population of approximately 4,500 in 1914, 292 men and 1 woman (a nurse with the US Army Medical Corps of the American Expeditionary Force) voluntarily attested for service overseas, the majority of these being posted to the largely Native $107^{\text {th }}$ and $114^{\text {th }}$ Battalions of the CEF. Of these, 29 were killed in action, 5 died of wounds or illness, one became a prisoner of war, and one was reported missing in action. ${ }^{65}$

The last time the Six Nations had taken to the field as an indigenous military force under their own leadership was during the Rebellions of 1837-1838. This included counter-insurgency operations in aid of militia in and around the hamlet of Scotland near Brantford, and at Navy Island and Chippawa on the Niagara frontier. In 1866 a quickly 
assembled homeguard of Grand River men stepped forward to offer their services to officials at the time of the Fenian incursion at Ridgeway to the southeast of the Reserve, but events had already stabilized before they could depart for the scene. ${ }^{66}$

Although at least one Grand River band member (Peter Martin) was serving with the Canadian militia as early as 1862 and possibly saw service with his unit $\left(2^{\text {nd }}\right.$ Battalion, Queen's Own Rifles) at Ridgeway, the first surviving reference concerning organized Six Nations participation in the mainstream militia movement comes as a protest from the Confederacy Chiefs, in council minutes dated 7 April 1885. In this instance, the Chiefs respond negatively to a request from area militia organizer, R.D. Nelles, that Six Nations band members be organized for service in the Northwest Rebellion, as part of the local militia unit, the $37^{\text {th }}$ Haldimand Rifles. ${ }^{67}$

The $37^{\text {th }}$ (Haldimand Rifles) Battalion of Canadian Militia was organized in 1866 following the Fenian incursion at Ridgeway. Although the Nelles request for Six Nations band members to begin serving with this unit in 1885 was rejected by the Chiefs, the Annual Report of the Department of Indian Affairs for the Six Nations Agency, for the year ending June 30, 1892, records two entire companies of Six Nations volunteers serving with this unit. In the January 1896 issue of The Indian Magazine, the Reserve newsletter published in Brantford, there appears an article by area lawyer and militia enthusiast Edward Chadwick, calling for the formation of an entire regiment composed exclusively of Six Nations residents. In his article, Chadwick notes that at the time of his writing, no fewer than 200 men of the Six Nations are on the militia roll, a number equaling that of Six Nations members taking to the field during the War of 1812. Chadwick continues that, given the interest expressed in the militia movement by Six 
Nations members, the time is at hand to raise an entire batalion of Grand River troops. He then describes a company structure based upon Six Nations tribal affiliations, with one company each, composed as follows: A Co. "Mohawks"; B Co. "Senecas"; C Co. "Onondagas" (who, as traditional keepers of the central council fire of the League, would also act as honour guard); D Co. "Tuscaroras"; E Co. "Oneidas and Delawares"; and F Co. "Cayugas". He further proposes (and includes a drawing of same) a unique uniform, comprising an eclectic blend of elements including gaiters, highland kilt, and headdress inspired by the traditional Iroquoian males' gustoweh. Lastly, he proposes colours, bearing War of 1812 honours for Queenston Heights, Beaver Dams, and the Niagara Frontier. ${ }^{68}$

Chadwick's call for an all-Six Nations battalion of Canadian militia was not acted upon, nor was a subsequent call to have the entire Six Nations complement of the $37^{\text {th }}$ Haldimand Rifles transferred en masse for fighting in the South African War of 1899 1902. ${ }^{69}$ However, Six Nations members remained active in the militia up to the declaration of war in August, 1914.

The $107^{\text {th }}$ and $114^{\text {th }}$ Battalions CEF were unique in Canada's Great War military establishment, in that these units were staffed by large numbers of Aboriginal Canadians. These were primarily status Indians from reserves in Ontario, Quebec, and the prairie provinces. Immediately upon the outbreak of the War, special interests stepped forward to advocate the raising of unique military formations, to be organized around particular geographic, ethnic, or occupational themes. The Princess Patricia's Canadian Light Infantry (ex-British military residing in Canada) and the $22^{\text {nd }}$ Battalion (FrenchCanadian) remain the best-known of these. In western and in central Canada respectively, 
A.G. Campbell and William Hamilton Merritt stepped forward to advocate the formation of fighting units to be composed largely, if not exclusively, of Native Canadians. ${ }^{70}$

Campbell was a wealthy rancher, a veteran of the Northwest Rebellion of 1885 , and senior Indian Affairs branch official in Winnipeg. On 4 November 1915 he was successful in his efforts to win approval for the raising of an entire CEF battalion to be composed of Canadian Indians and western cattlemen. Although approximately 500 of the original 900 volunteers to the $107^{\text {th }}$ Battalion were Native, the unit continued to evolve both before and after its arrival in England, and later France. Eventually designated as infantry pioneers with responsibilities for specialized combat engineering tasks that included the breaching of enemy strongpoints under fire, the $107^{\text {th }}$ continued to transfer men in and out its ranks. Many were selected as replacements to other lower numbered battalions already at the Front. The military in turn made special efforts to have Indian commissioned officers and NCO's transferred into the unit. Ultimately, the equivalent of two of its four companies were manned and officered by Canadian Indians. The Battalion particularly distinguished itself during the heavy fighting for Hill 70 near Vimy in August, 1917. However, at the end of March, 1918, at the height of the German Spring Offensive, the $107^{\text {th }}$ Battalion was disbanded, and its surviving members redistributed among three newly organized engineering battalions within the Canadian 1st Infantry Division. ${ }^{71}$

Even before the outbreak of the First World War, the military prowess of the Six Nations was receiving special recognition in Canada. The years 1912 through 1914 across central and eastern Canada had seen numerous centennial commemorations of the War of 1812, and discussion of its influence upon the subsequent development of Canada 
as a dominion within the British Empire was widespread. A recurring feature within such commemorations and memorials had been the role of First Nations fighters as valuable military allies to the Crown in defence of Upper Canada. ${ }^{72}$ Thus when war was declared on 4 August 1914, the potential role of Natives in this new global conflict was not far removed from the public consciousness, or from that of government officials and other functionaries. A telegram dated 19 August 1914 from the Six Nations Indian Office at Brantford, signed by acting Indian agent Hilton Hill, himself a Six Nations band member, to deputy superintendent general Duncan Campbell Scott in Ottawa, provided the names of the first eight Grand River band members to volunteer for active service. ${ }^{73}$

William Hamilton Merritt was a noted mining engineer and militia officer from southwestern Ontario, a veteran of both the Northwest Rebellion and the South African War. Merritt, a well-known figure among the Six Nations, had been named an honourary chief by the Cayuga and had polled the majority of the Indian vote in Haldimand County during a federal by-election of 1886 , in which Six Nations adult males meeting the property requirement had been eligible to vote under the terms of the briefly held Macdonald Franchise. As founding president of the Canadian Defence League in 1909 (which position he retained until his death in 1918), Merritt advocated imperial defence and military preparedness for the Dominion, including compulsory service for all ablebodied males in Canada between the ages of 20 and 48 in a militia structure based upon the Swiss national army of citizen-soldiers. The grandson of an earlier William Hamilton Merritt who was a major backer of both the Welland Canal and the less fortunate Grand River Navigation Company, the younger W.H. Merritt offered the sum of $\$ 25,000$ of his own money at the outbreak of the War to raise and equip two companies of Six Nations 
Indians for service overseas. Merritt envisaged his unit as a timely centennial tribute to the participation of members of the Six Nations who fought alongside Canadian militia and British regulars during the War of $1812 .{ }^{74}$ However, not having properly consulted with the Six Nations Council of Confederacy Chiefs in advocating what was essentially the raising of a private army from among its citizens, Merritt's initial plan was rejected. ${ }^{75}$ The chiefs took special pains to explain that the Six Nations Confederacy was an independent sovereign state under international law, and that until such time as the British Sovereign made a direct appeal for its aid, or until such time as Germany herself declared war upon the Six Nations Confederacy of Iroquois, the chiefs were compelled under Iroquois customary law to maintain a stance of diplomatic neutrality. But the chiefs then indicated that if it was the personal choice of individual band members to volunteer for duty with the CEF or other forces of the British Empire, they were free to do so. The chiefs, however, would not officially endorse any such undertakings, nor would they allow any recruiting to occur on reserve lands. This last proviso was to come to a head in 1916 when, stunned by their hostile reception at an attempted recruiting fair in the Reserve's village centre at Ohsweken, Army officials in a formal communiqué to their superiors actually accused the chiefs of acting in collusion with German agents on the Reserve. $^{76}$

Merritt's specific plan for a privately funded and equipped unit of Six Nations fighters thus never fully materialized. However, by the autumn of 1915 the $114^{\text {th }}$ Battalion was organized within the existing CEF structure, to be raised among volunteers from Brant and Haldimand counties, which included the full extent of the Six Nations Reserve. In short order, the number of volunteers forthcoming enabled the organization 
of two of the Battalion's four companies as being all-Six Nations; its insignia, incorporated beneath the standard CEF maple leaf cap badge, being a device of two crossed tomahawks and the motto, "Brock's Rangers". This was in deference to the ancestry of many of its members who were descended from the Six Nations irregulars who had skirmished alongside Brock's British regulars and Upper Canadian militiamen a century before. The $114^{\text {th }}$ Battalion CEF, "Brock's Rangers", was initially organized under the command of Colonel E.S. Baxter, who was succeeded in command by Lt. Col. Andrew Thorburn Thompson. However, as with many other battalions of the CEF by this stage of the War, the $114^{\text {th }}$ was disbanded soon after its arrival in England, with its members being assigned as reinforcements to other lower numbered battalions already at the Front. The bulk of these former members were transferred to the $107^{\text {th }}$ Battalion already described. It was while serving with this unit at the Front that the Six Nations troops undertook their agitation for political change back at Grand River.

With the Six Nations troops overseas, a number of events unfolded on the reserve which served to invoke the troops' ire with respect to the war stance of the Confederacy Chiefs. Principal among these was the chiefs' continued negative attitude toward recruiting on reserve lands; their unwillingness to provide financial assistance to soldiers' family members from among band funds; and the chiefs' vow that come peacetime they were not prepared to see reserve lands given over in fee simple ownership to returning Six Nations veterans, as they perceived the terms of the proposed Soldier Settlement Act, then in draft.

By mid-War, conciliatory chiefs like John Arthur Gibson and Josiah Hill had passed away, to be replaced by more strident voices. ${ }^{77}$ Three distinct groups emerged 
within Council: that portion willing to consider introduction of an elective system, a moderate element seeking to retain Six Nations local autonomy and self-determination but with better relations with the Dominion government ${ }^{78}$, and a radical group under Cayuga chief Deskaheh, or Levi General, unwilling to settle for anything less than full sovereignty as an independent nation-state under international law. ${ }^{79}$ This sovereigntist element ultimately gained ascendancy within Council. ${ }^{80}$ That the demise of conciliatory and moderate leadership within Council, as exemplified by chiefs like Josiah Hill, and the ascendancy of more radical voices like Deskaheh, should occur in the midst of the volatile conditions created by Dominion and Six Nations involvement in the First World War, was most unfortunate.

Many of the Six Nations troops were the sons and grandsons of some of the original reform agitators in the Dehorner movement. A few of the older soldiers were active themselves in the movement from before the War. In response to the chiefs' attitude, these frontline troops soon coalesced as a distinct reform movement in their own right, and as an adjunct to the existing Dehorners. Their first petition is dated France, 8 August 1917, just days before their involvement in the fighting for Hill 70 near Vimy and Lens. It had been drafted and circulated by Grand River commissioned officers and NCO's including Captain A.G.E. Smith, Lieutenants Oliver Martin, James Moses, and Frank Montour, and Sergeant William F. Powless. ${ }^{81}$ Other surnames appearing on the petition provide an overview of Grand River family names as these existed during the early twentieth century: Clinch, Johnson, Cayuaga, Hill, Staats, Williams, Bomberry, Lewis, Crain, Groat, Silversmith, General, Porter, Sherry, Joseph, Green, Longboat, Bearfoot, Clause, Vyse, White, Wilson, Adams, Newhouse, Burnham, Styres, and 
Curly ${ }^{82}$ Grand River troops had been widely dispersed following the disbanding of the original $114^{\text {th }}$ Battalion, and although many were transferred to the $107^{\text {th }}$ Battalion Canadian Pioneers, other units indicated on the petition include the $4^{\text {th }}$ and $20^{\text {th }}$ Battalions CEF. Oral histories provided by Six Nations descendants today concerning their ancestors' Great War service records reveal that other units in which Dehorner troops served included formations of the Canadian Railway Troops and the Canadian Forestry Corps. The petition's preamble reads as follows (original spelling, punctuation, and grammar retained):

We the undersigned soldiers in the Canadian Expeditionary Force, and members of the Six Nations Indians, of the Grand River, regret very much that circumstances have made it so, we can no longer look on our present council with respect and confidence, and we therefore sign this as an agreement, to do all in our power to rid our nation of the said council, and in its place to establish a government representative of the people, whereby we as Six Nations Indians, in general, may be intelligently represented, and that our public affairs and national spirit may be properly looked after. (57 signatures)(Canada, 1917b).

The conduct of the War on the Western Front was of course the main preoccupation of the Six Nations soldiers on active service in the field. This was the only petition they were to submit from the Front, and within the following days, weeks, and months, a number of the original signatories paid the supreme sacrifice.

Those units of the CEF comprising the divisions of the Canadian Corps on the Western Front during the First World War had arrived at the Front after having received training at Camp Hughes and Valcartier Camp in Canada, and on the Salisbury Plain and at other locations in Great Britain. They honed their skills in battle under Canadian leadership, and from the time of their significant victories at Vimy Ridge in April, 1917 through to the end of the Great War (Canada's "Hundred Days" from 8 August to 11 
November 1918) had transformed themselves into a formidable military force on behalf the Allied effort. Indeed, in some quarters they were referred to as the "Shock Army of the British Empire." They had furthermore become a significant expression of Canadian nationalism at home and upon the international stage. Their ultimate success had been dependant upon the personal skills, adaptability and resilience of the individual Canadian fighting man, acting under Canadian leadership. Total enlistments for the CEF (including those later seconded to the Royal Flying Corps, the Royal Naval Air Service, and ultimately the Royal Air Force) numbered 730,159. Naval enlistments were estimated at approximately $7,000 .{ }^{83}$ In all, 66,573 Canadians lost their lives, 138,166 were wounded, and 2,818 became prisoners of war. 175 Canadian merchant seamen were killed. ${ }^{84}$ The annual report of the Indian Affairs Branch for the fiscal year ending 31 March 1919 recorded total status Indian enlistments during the conflict at "more than four thousand", noting that this figure represented approximately $35 \%$ of status Indian males of military age, and that there were undoubtedly many cases of Indian enlistments (including those into the United States armed services) not reported to the Branch. ${ }^{85}$ An unrecorded number of non-status Indian, Métis, and Inuit also served. Although never subsequently acted upon, there was at least one official call from district military commander General Cruikshank, with the support of the provincial lieutenant-governor, for the formation of an all "Half-breed" battalion to be raised among Métis recruits in Alberta. ${ }^{86}$

Canadian servicemen in the First World War encountered combat in all those new forms which characterized fighting in that conflict: trench warfare and poison gas, automatic weapons and rapid-fire artillery, and the introduction of mechanized armour and airpower. Although when war was declared in 1914, Canada was automatically at 
war as a function of its status as a mere colony within the British Empire, following the Armistice of 11 November 1918 when the Treaty of Versailles was concluded in 1919, Canada signed as a fully independent nation, with a seat at the League of Nations. This fact was to take on added significance when considered in view of subsequent competing efforts of the Confederacy to assert Iroquois sovereignty on the word stage.

The $107^{\text {th }}$ Battalion Canadian Pioneers, to which many of the Dehorners were posted following the disbanding of the $114^{\text {th }}$ Battalion, represented a tactical and operational innovation, one of the new features of warfare on the Western Front during the Great War. A supporting premise of this thesis research is that the combat experiences of the Grand River volunteers were instrumental in shaping their postwar ideology and thinking. ${ }^{87}$ In brief, pioneers were conceived and used to provide a pool of "organized and intelligent labour" under fire, and were embedded directly within frontline combat units. Known today as combat engineers, independent battalions of frontline infantry pioneers existed within the CEF structure from 1915 until the spring of 1918, at which time they were disbanded and their surviving number amalgamated into existing engineering battalions. Beyond their ordinary training as combat infantry, their specialized task was to breach enemy obstacles and entrenchments under fire as attacking units stormed forward: newly captured German trenches, pillboxes, and other fortified positions had to be rapidly modified and consolidated to prevent their recapture, and booby traps and improvised explosive devices left behind by the enemy had to be identified and neutralized. New communications trenches had to be dug forward across the broad expanse of no man's land to link the old frontline Allied trenches with newly captured German ones. Additionally, narrow gauge railroad tracks had to be laid in order 
that quantities of ammunition, artillery shells, and other supplies could be rapidly brought forward before the Germans could regroup and counter-attack. Canadian infantry pioneers were also amongst those troops engaged in tunneling directly beneath the enemy's trenches, in order to pack the excavated galleries with high explosive for later detonation.

Such was the lot of officers, NCO's, and private soldiers from Grand River, during the spring and summer of 1917 when the $107^{\text {th }}$ Battalion was engaged in some of its heaviest fighting. Canadian Corps commander Arthur Currie described the fighting for Hill 70 during August, 1917, and in which battle the $107^{\text {th }}$ Battalion was fully engaged, as "altogether the hardest battle in which the Corps has participated." 88

It is thus useful to ponder the extent to which shared dangers experienced in common upon the battlefields of the Somme and the Ypres Salient, and the personal and group philosophies thus forged, might influence attitudes toward traditional government and hereditary leadership at the Grand River Reserve. Despite the hierarchies implicit with military rank structure, and the different roles and responsibilities assigned servicemen according to their relative status as commissioned officers, private soldiers, or non-commissioned officers, the leveling effects of life in the trenches must not be overlooked: officers and non-commissioned officers became effective leaders only so far as they instilled confidence in their men and earned their individual respect. As holders of the King's commission, lone officers might have legal authority over men's movements and actions (and thus ultimately their lives); it was, however, force of personality and strength of character which inspired the men under their command to follow their orders willingly. This, then, is the fundamental difference between ascribed status, and achieved 
status; between traditional leadership based upon birth and heredity; and democratic leadership based upon individual attainment and publicly demonstrated ability. Conversely, regiments and battalions of individual soldiers in wartime, as with coalitions of private citizens in peace, typically held the de facto balance of power with respect to their nominal leaders anyway: just as ordinary citizens might conceivably resort to revolution during peace, so too could troops mutiny during wartime. Mutinies and a range of lesser "disturbances" including riots were not unheard of amongst troops of the CEF during the Great War. ${ }^{89}$ In short, there was a carefully nurtured and delicately balanced social bond, a democracy born of the trenches, to which non-combatants could never be party.

It is worth noting that the two names appearing at the top of the August 1917 Soldiers' Petition are those of Lieutenants J.D. Moses and O.M. Martin, two of the $107^{\text {th }}$ Battalion's Indian commissioned officers from Six Nations. Subsequently posted for flight training to the Royal Flying Corps, Moses' and Martin's war service records are especially noteworthy in that these two men from Grand River were among the three Canadian status Indians who would hold commissions as flying officers in the British flying services during the Great War. The other was John Randolph Stacey, a Mohawk from Kahnawake who qualified as an RAF pilot, but who was killed in a flying accident in England on 8 April 1918, just a week after Lt. Moses would be reported missing. Moses and Martin were the elder sons of leading Dehorner families on the Six Nations reserve, had been attested directly into the CEF as commissioned officers, and were promoters and organizers of the Dehorner cause among the Six Nations troops overseas. Martin survived the war but eventually turned his back on Six Nations politics 
and Indian Affairs bureaucracy, taking voluntary enfranchisement during the 1920's, and eventually achieving high rank in the Canadian Army. Moses was killed. Their respective destinies represent in microcosm the fortune of war and its unanticipated outcomes. Insofar as these two officers were the leaders of the dissident Dehorner movement in the trenches overseas, their individual service records and ultimate fates are worthy of discussion.

By the last year of the Great War an extensive and highly regulated infrastructure existed to meet the training needs of the flying services of the British Empire. With the exception of an autonomous Australian Flying Corps notwithstanding, until 1 April 1918 these consisted of the Royal Flying Corps, the Royal Naval Air Service, and a separate Kite Balloon Section of Royal Artillery and Royal Engineers artillery observation officers seconded to the RFC. Although direct enrolments or transfers to pilot training within the RFC were periodically available on a limited basis, in fact the more common route to pilot's wings for aspiring military aviators was secondment from another branch of service, and completion of aerial gunnery, artillery spotting, photography, and telegraphy training, culminating in a requisite period of duty as an artillery observer and air gunner, before being forwarded to pilot training. This was in fact the scenario followed by Moses, Stacey, and Martin, the three having previously served as infantry officers with the $114^{\text {th }}$ and $107^{\text {th }}$ Battalions CEF.

As described, Lt. Oliver Milton Martin was the second Grand River commissioned officer (and Dehorner), to see action with the RFC/RAF, and the third Canadian status Indian overall to hold an officer's commission with the British flying services. As events transpired, he was the only one to survive the War. Like Moses, 
Martin was seconded to the RFC in September, 1917. He survived his requisite period of service as an observer and air gunner, successfully completed pilot training, and was granted his wings on 30 July 1918. Following his war service, demobilization, and return to Canada, Martin attended teachers' college, graduating from Toronto Normal School in 1922. Working as a school teacher back at Six Nations, Martin stayed active with the Non-Permanent Active Militia, eventually becoming Commanding Officer of the $37^{\text {th }}$ Haldimand Rifles. He had been associated with this unit as a non-commissioned member prior to the First World War, having originally served as early as 1909 as a bugler for the Haldimand Rifles at the annual militia training camp at Niagara-on-the-Lake. In 1936 the Haldimand Rifles were amalgamated with the Dufferin Rifles, to become the Dufferin \& Haldimand Rifles. Martin held successive appointments as Commanding Officer of the Haldimand Rifles, and eventually the Dufferin \& Haldimand Rifles, from 1930 through 1937.

Having become disillusioned with Grand River politics and seeking escape from irksome Indian Affairs Branch meddling in his personal affairs, Martin undertook voluntary enfranchisement and thus surrendered his legal Indian status in $1921 .{ }^{90}$ Martin married in 1935 and moved to Toronto, where by 1937 he had been appointed as principal of Danforth Park Public School. During that same year Martin was chosen as a member of the Canadian military contingent present in London, England, at the coronation of King George VI, the sole Canadian Indian in attendance. At the outbreak of the Second World War, Martin returned to active duty as a colonel in command of the $4^{\text {th }}$ Canadian Infantry Brigade, Reserve Army. Martin in November, 1940, at the age of 47, was appointed Brigadier commanding the $14^{\text {th }}$ (Nanaimo) and $16^{\text {th }}$ (Prince George) 
Infantry Training Brigades on the West Coast. Martin's last military posting before retirement from the service in October, 1944, was to an Infantry Training School Conference in Scotland. Following his retirement from the military, Martin was appointed a provincial court magistrate for Ontario's $6^{\text {th }}$ District, encompassing the York, Halton and Peel regions. Martin attended Queen Elizabeth's coronation in 1953 as a member of the official Canadian military and civil delegation. O.M. Martin died in 1968. Lt. J.D. Moses' brief service as a flying officer is also noteworthy on a number of counts: as indicated, he was one of only 3 Canadian status Indians to hold an officer's commission in the RFC/RAF during the First World War. Additionally he and his pilot were reported missing by the RAF on the first day of its operational existence on 1 April 1918 (the day on which the former RNAS and RFC amalgamated to create the RAF proper), and it has been disclosed that the destruction of the $\mathrm{DH} 4$ aircraft in which he was crewing that day was attributed by the German Air Force to one Ltn. Hans Joachim Wolff, a member of Jagdgeschwader von Richtofen, more commonly known in English as the Red Baron's Flying Circus. ${ }^{91}$ These particular facts notwithstanding, the training he received as an artillery observer and air gunner was typical for an aspiring aviator from the Canadian dominion during the closing stages of the First World War. Moses had previously trained and served as an infantry officer with the $37^{\text {th }}$ Haldimand Rifles of Canadian Militia, and with the $114^{\text {th }}$ and $107^{\text {th }}$ Battalions of the CEF, from the date of his enlistment on 19 November 1915, until he was seconded to the RFC. Moses was in action with his battalion as an infantry pioneer officer at various locales across the Somme River valley in France and on the Ypres Salient in Flanders from the time of the $107^{\text {th }}$ 's arrival on the continent in February 1917, and he was present with the $107^{\text {th }}$ in the heavy fighting 
for Hill 70 near Lens from 15 - 25 August 1917. On 3 September 1917 he was transferred for duty as an Army Observer with the Royal Flying Corps. He began flight training as an air observer in England on 19 September 1917, and on 3 January 1918 he returned to France where on 8 January he was attached for duty with 57 Squadron RFC, based then at St. Marie Cappel. 57 Squadron at this stage of the War was a reconnaissance and bomber squadron equipped with De Havilland DH4 2-seater day bombers, and as events transpired, it would soon be heavily involved in air operations and ground support missions aimed at countering the massive German Spring Offensive of March 1918. From 21 January through 31 March 1918, Moses as an artillery observer and air gunner successfully completed a total of 13 bombing raids and 17 photographic, artillery spotting, and related reconnaissance flights.

On 1 April 1918, upon the day on which the former RNAS and RFC were amalgamated to create the Royal Air Force, James Moses and his pilot Douglas Price Trollip were reported "Missing" over Bapaume, France, following their 14th daylight bombing run together. The names of Lt. James David Moses, aged 28, originally a school teacher on the Six Nations Reserve, and $2^{\text {nd }}$ Lt. Douglas Price Trollip, aged 23, are duly inscribed on the No Known Grave Memorial for the Flying Services, at Arras, France.

The Moses family today on the Six Nations reserve retains in its possession a set of original correspondence and related documents and photographs shedding light on the war service record and brief First World War flying career of Lt. Moses. The letters, photographs and telegrams comprising this record are of interest on a number of levels. Technically, they provide insight into RFC/RAF photo reconnaissance work, artillery spotting, ground support, and day bombing operations on the Western Front at the height 
of the final great German offensive of the War; and they provide enthralling detail into the genesis of close air support and ground attack by air power operating in support of infantry. Politically, they shed light on the Great War military service of one Native Canadian in the forces of the British Empire, recalling an alliance between the British Crown and the Six Nations Indians and allied nations that reaches back to the $17^{\text {th }}$ century. To the extent that Moses was the son of Nelson Moses, a founder of the Dehorner party, and was himself a leader of the Dehorner movement, the letters also ultimately relate to the experiences of reform sympathizers in wartime. Finally, on a humanitarian level, they testify to some of the last recorded thoughts and feelings of a young aviator engaged in the hazardous duty of flying operations over the Western Front in the closing stages of the First World War. James Moses in peacetime had been a teacher in a one-room schoolhouse on the Six Nations reserve. The cumulative effects of his months of war service both as an infantry officer in an assault Pioneer unit and subsequently as an air gunner, are apparent in the graphic quality of the letters he wrote home to his father. One extract will suffice:

France, March 30, 1918

Dear Dad ... Just a few lines to let you know that I am getting along O.K ... My pilot and I have had some very thrilling experiences just lately. We bombed the German troops from a very low height and had the pleasure of shooting hundreds of rounds into dense masses of them with my machine gun. They simply scattered and tumbled in all directions. Needless to say we got it pretty hot and when we got back to the aerodrome found that our machine was pretty well shot up.

Lt. Moses was reported missing two days later, his father receiving the following telegram dated 5 April 1918,

Sir

I am commanded by the Air Council to confirm a telegram from this office to notify you that Lt. J.D. Moses of the Royal Air Force is missing. I am to point out 
this does not necessarily mean that he is killed or wounded and to say that you shall be immediately informed as soon as any definite news is received.

Should you receive any further information from any source [i.e. the International Red Cross] I am to request that you will communicate immediately with this office.

Dehorner Nelson Moses, father of Lt. Moses, wrote a moving poem entitled The Missing Airman upon receiving word of the fate of his missing son. The poem was subsequently published in a local newspaper, likely the Brantford Expositor. ${ }^{92}$ An obituary and article concerning the fate of Lt. John Randolph Stacey (a Kahnawake Mohawk educated with Six Nations band members at the Mohawk Institute residential school at Brantford), appearing in the Toronto Evening Telegram for the edition of 12 April 1918 (one week following notification of the loss of James Moses) appeared under the headline,

Killed While Flying Lieut. John R. Stacey, A Young Iroquois Officer Meets His Death $\sim$ Lieut. John Randolph Stacey, one of the four Iroquois officers who went overseas in Brock's Rangers, has met his death through an airplane accident.

This apparent preparedness to accept the loss of family members as a fortune of war by those Six Nations band members who supported the Dominion war effort stood in stark contrast to the stance of those families which did not support Grand River involvement in the conflict. It must be acknowledged of course that from their own perspective, the Council of Confederacy Chiefs and its supporters did indeed have legitimate claims for special status, both with respect to the British Crown and the Dominion of Canada. Accordingly, a petition submitted by a group of Six Nations clanmothers, directly to King George V at Buckingham Palace, is quoted here in full. The clanmothers are protesting the alleged underage enlistment of some of their sons, 
demanding of the King that he release them forthwith from his military service (original spelling, punctuation, and grammar retained):

Six Nations Indians Reserve Grand River, Kanyengeh Post Office

Brant County, Ont. Canada

January $31^{\text {st }} 1917$.

To His Majesty King George V of England.

May it please Your Majesty to listen of our pressing business, to lay it before Your Majesty and it is this. We the undersigned our Sons a young men, they are not of age, but they enlisted in Your Majesty's army by the persuasion of other men, therefore send them home.

And our ground for asking Your Majesty to discharge our Sons is this, as Your Majesty see in this letter engraved and inserded a "Wampum belt Treaty", between Us the Five Nations (now Six) and Your's British Nation's Government.

And the Wampum belt Treaty is inserded in here.

[a photograph of the Covenant Chain belt is pasted to the page]

Having one row and Two Men standing, one man at each end of the row, holding the Covenent Silver Chain. This signifies the Two Nations. And the first Nation is Mohawks, Oneidas, Onondagas, Cayugas, and Senecas, holding one end of the Covenent Silver Chain, and the British Nations holding the other end of the Covenent Silver Chain. Thus the two Nations did Covenented themselves together as Allies, to defend one another in case of war.

And if the British is in War and if the British needs help, then the King or Queen will write a letter to the Governor General of Canada to ask the Six Nations Union Lords, now commonly called chiefs. To ask them, to help the British in their War.

Then the Six Nations Union Lords will hold a Council and they shall decide in their Council to help the British in their War. Then the Six Nations Union Lords will address to the Five War Chiefs, to prepare and get ready their common Warriors to go and help the British in their War.

And the next Wampum belt Treaty of Two rows in here.

[a photograph of the Two Row Wampum is pasted to the page] 
This two rows of Wampum belt Treaty. Signifies the Two separate Government shall exist. Namely; - the Mohawks, Oneidas, Onondagas, Cayugas, and Senecas, and the British Nation's Government. So the Two Saparate Government shall exist and Independently from each other, forever.

And the Six Nations shall not Rule over the British Nation. And the British Nations shall not Rule over the Six Nations. And the following names are enlisted in Your Majesty's army.

Pte. Robert Sky 739597 B. Co. $35^{\text {th }}$ Batt West Sendling Camp. London. England Pte. James Williams Company A Coy Batt 35 Regt. 739810 Pte. Hardie Fish Fifth Canadian Reserve 35 Battalion CEF B Company Reg. No. 739941 Army P.O. London, England.

Pte. Willie Fish, $4^{\text {th }}$ Canadian Reserve 35 Battalion CEF B. Company Regt. No. 7.3.9.5.3.6 Army P.O. London England.

No. 7.3.9.8.2.1. Pte. Josie Bumberry. B Coy. $4^{\text {th }}$ Canadian Reserve Btn. West Sandling Camp. Army P.O. London. England.

[signed] Joseph Sky $\mathrm{x}$ his mark Lucinda Bumberry Maggie Williams x her mark Mrs. Elizabeth Fish (Canada, 1917a)

The ethnographic literature pertaining to the role of women in Iroquois society is vast, and the status accorded clanmothers in selecting chiefs from among the pool of eligible male candidates according to clan affiliation is often singled out for special attention. ${ }^{93}$ As ethnologist A.A. Goldenweiser described the role of Iroquois clanmothers in a paper published just months before the outbreak of war, following a period of fieldwork at Grand River,

While women could not be chiefs and had no vote in tribal or federal councils, their functions in connection with the election and deposition of chiefs constituted them a most important factor in Iroquois society. Moreover, prominent women often addressed councils, some were noted for their eloquence, and, in all cases, the opinion of women was asked and heeded. (Goldenweiser, 1914, 376-377). 
The Clanmothers' Petition quoted above is remarkable in its use of both Englishlanguage text and the symbolism and iconography of Iroquoian wampum belt culture to drive home its point concerning the continuity of Grand River sovereignty with respect to the British Crown, the two belts illustrated being the Covenant Chain belt, and the Two Row Wampum. It is significant that the petition is addressed directly to King George V. A faint impression at the upper left corner of the original document contains the stamp of the King's private secretary, indicating that the petition made it as far as Buckingham Palace in its overseas journey. It is unknown, however, if the petition was read by the King himself, before being referred back to the Canadian Governor General. That the document was sent to the King is indicative of the Council's view by that stage that the Dominion of Canada was incompetent to comment upon matters pertaining to the Six Nations of the Grand River and its citizens, and that any matters pertaining to the Six Nations were beyond Canadian jurisdiction and must be dealt with directly at the level of the sovereign.

Some wampum belts refer to pre-Contact political accords between indigenous First Nations; or, post-Contact, between these First Nations and the earliest European newcomers and their colonial successors. Certain recurring symbols serve as the distinguishing features of belts. Among these elements, four of the most compelling are those symbolizing the fire, the path, the chain, and the prop. These are iconic within wampum culture, their significance being understood across linguistic and national boundaries. The fire is typically hexagonal or roughly circular in shape. It represents the territory or the seat of government of a specific First Nation within a Confederacy, or as a party to some accord. The path is often rendered as a jagged line or serrated "lightning 
bolt", representing the notion of movement, commerce, exchange, or travel between nations. The chain is most often depicted as a straight horizontal line, often doubled, and signifies mutual aid and reciprocity between sovereign bodies: military aid during war, and economic and trading partnership during peace. Finally, the prop most often appears as a diagonal line, and represents specific nations or communities as secondary parties or adhesions to a pre-existing confederation or accord.

The Covenant Chain and the Two Row Wampum belts depicted in the petition are both variations upon the theme of the chain. Their specific respective meanings are concisely described by the clanmothers themselves in their petition: the Covenant Chain as a diplomatic agreement between two consenting parties to provide mutual defence during wartime; the Two Row Wampum as a manifestation of the condition of sovereignty association existing between two governments, namely the Six Nations Confederacy and the British Crown. In drawing these two significant wampum records to the attention of the reigning British Sovereign, the clanmothers are taking the opportunity to remind His Majesty of the historic relationship between the Crown and the Confederacy.

Unfortunately for the clanmothers, their invocation of Iroquois sovereignty as a grounds for release from His Majesty's Service of the Grand River soldiers named therein is self-defeating: any of their rights of citizenship conferred by a putative Six Nations sovereignty were extinguished upon the recruits' freely given oath of allegiance to King George V, the text of which is explicit,

I, ..., do make Oath, that I will be faithful and bear true Allegiance to His Majesty King George the Fifth, His Heirs and Successors, and that I will as in duty bound honestly and faithfully defend His Majesty, His Heirs and Successors, in Person, Crown, and Dignity, against all enemies, and will observe and obey all orders of 
His Majesty, His Heirs and Successors, and of all the Generals and Officers set over me. So help me God.

While it is unclear whether or not any the recruits named in the petition were ultimately released in view of underage enlistment as alleged, it is known that each survived the War, none of their names appearing on the Six Nations Indian War Memorial in the Six Nations village square at Ohsweken.

Conversely, the reputation of those Six Nations band members who during 19141918 willingly played an active part in the Dominion's war effort had grown in the estimation of the Canadian public. During wartime letters to the editors of newspapers, magazines and journals kept Six Nations participation in Canada's military effort overseas before the public eye. A letter to the editor published in the Toronto Star on 15 September 1917, from Six Nations Indian agent Hilton Hill, provided the names of seven commissioned officers from Grand River serving in the CEF or Royal Flying Corps by that date. Extracts from Militia Standing Orders detailing enlistments, promotions, and appointments within the $37^{\text {th }}$ Haldimand Rifles were not deemed classified and were distributed, ${ }^{94}$ while the names appearing in sailing orders for the $114^{\text {th }}$ Battalion CEF, on whose strength most Six Nations troops had traveled overseas, were made available upon the troops' safe arrival in the UK. ${ }^{95}$ Articles in Scottish newspapers (to which region of the British Isles companies of the $114^{\text {th }}$ had been dispatched for further training upon their arrival in the UK) reveal the novelty for local residents of encountering North American Indians in person for the first time. ${ }^{96}$ An article including mention of Six Nations troops in the CEF by American anthropologist Arthur C. Parker (himself a Seneca from New York State) was published in a U.S. journal, "The Southern Workman." 97 Through such means citizens and band members were kept apprised of the 
progress of the Six Nations troops as they embarked upon active service. As with other Canadian families across all parts of the Dominion, news and information contained in letters home was shared selectively amongst close friends and other relatives. A remarkable letter home written in the Mohawk language from Private Elmer Jamieson to his father Augustus Jamieson somehow managed to elude military censors, and provided the folks back home some of the first news that the $114^{\text {th }}$ Battalion had been disbanded with many of its former members transferred for service as infantry pioneers with the $107^{\text {th }}$ Battalion. $^{98}$

Families and neighbours grieved together as word was received of those reported killed, missing, or wounded. As Jonathan Vance has described with respect to Canadian society generally during the war,

On any given day, dozens and perhaps hundreds of households might receive the fateful telegram that bore the news dreaded by all. The war was no respecter of class, or region, or religion, and the constancy of death may well have imparted an odd sort of unity to Canadian society as so many people tried to come to terms with the same experience ... at the very least ... the losses of 1914-18 constituted a profound psychic shock, and made mourning an almost universal condition. (Vance, 2005, 412-413).

In an ironic turn of events, Six Nations band member Private Adam Sandy was returned to Canada for special service soon after the arrival of the $114^{\text {th }}$ Battalion overseas. Deemed too old for frontline service at age 45, Private Sandy was assigned as a military guard at the port of Halifax and was killed in the Halifax Explosion of 6 December 1917 while standing duty at Richmond Piers. His name and regimental affiliation duly appeared in a casualty list of the explosion published in the Halifax Herald on 12 December $1917 .^{99}$ 
Perhaps somewhat surprisingly given its negative attitude toward the Dominion effort during wartime, the council recorded its receipt of news of the Armistice on 11 November 1918 as follows:

Ohsweken Council House November 12, 1918

Minutes of Council Meeting.

The Council decided to ask Chief David John, one of the Fire Keepers to return thanks to the Great Spirit for the final victory He has seen fit to give the Allied Nations and for His Blessings and Guidance during this great conflict.

Chief David John Accepted the invitation of the Council and did at some length invoke the Blessings of the Great Spirit according to the customs of the Six Nations and congratulated His Majesty the King and also the Canadian Government. ${ }^{100}$

Several days later, a portion of the Confederacy Chiefs in Council forwarded the following telegram (arguably at odds with previous and subsequent assertions of Six Nations sovereignty) to George V on 22 November 1918,

His Majesty the King Brantford, November 22, 1918 London, England.

This Six Nations Indians in Council assembled, beg to renew pledge of loyalty to British Crown and join with Your Majesty in thanks to Great Spirit for blessings. ${ }^{101}$

In conclusion, the volatile political and emotional environment created by Canada's involvement in the Allied war effort exacerbated preexisting tensions between the Confederacy Chiefs, clanmothers, and their supporters on the one hand, and dissident Dehorners and their supporters on the other. The passing of moderate chiefs including J.A. Gibson and Josiah Hill facilitated the emergence of more strident sovereigntist voices like Deskaheh. The Confederacy Chiefs espoused Iroquois sovereignty and diplomatic neutrality during the First World War. Despite this stance, approximately 300 
band members attested for service with the CEF and other Allied armies, thus further undermining the authority of the Confederacy system. Successive moves during wartime by Confederacy supporters to assert Iroquois sovereignty (such as the Clanmothers' 1917 Petition to the King) further alienated the Six Nations troops overseas, and their supporters at home, this time including the Dominion government. 


\section{Chapter 4: The Return of the Six Nations Veterans and the Implementation of Band}

\section{Council Rule}

In addition to claims for compensation and other entitlements which Six Nations soldiers shared with all newly returned soldiers across the Dominion in 1919 , some of the the returning Six Nations veterans harboured unique grievances as Grand River band members. Having internalized Dehorner ideology overseas, many came back intent on having government intervene on their side in removing the Confederacy Chiefs from power. Their status as specialist troops during wartime notwithstanding, Six Nations soldiers returning home found common cause with the vast multitude of Great War veterans in former belligerent states across the globe: having fought for the national if not imperial interests of their respective countries, they now returned home to governments which viewed them with ambivalence, if not outright suspicion. ${ }^{102}$ Great War veterans across the country felt a disconnect between the magnitude of their wartime sacrifices overseas, and the political, economic, and social prospects to which they returned in peacetime. So did a portion of the Six Nations veterans. They returned to an environment which many of them found unresponsive to their needs and aspirations.

Debates concerning the First World War as a force for continuity or change continue. Tim Cook has described the war as "both the end of an era and a harbinger for the future." 103 Jonathan Vance has observed that while some historians have examined the war from the vantage point of the modern age, others have described it within the context of the Victorian era which preceded it. ${ }^{104}$ In many ways the Euro-North American experience of the Great War signaled the demise of the traditional authority of kings and empires and marked the advent of modernity. Previous metanarratives were open to 
challenge, and cherished national or imperial mythologies could be dispensed with altogether. Some disaffected veterans, depending upon national circumstances and outlook, manifested anomic or nihilistic behaviors, as with those who participated in the German Freikorps movement ${ }^{105}$ or the British Union of Fascists. ${ }^{106}$ Others chose to work within existing structures to implement change. Within a specifically Canadian context, while it was not immediately anticipated that Canada's newly returned soldiers as a body were necessarily inclined toward violent or revolutionary reforms, they were recognized as constituting a force for change, and their endorsement of a particular policy brought status to a cause. Accordingly, strategists and spokespersons from left to right across the spectrum of politics and civil society liked to assert that their particular platforms enjoyed the greatest support amongst the constituency of veterans as they advanced their respective reform agendas. ${ }^{107}$

A uniquely Canadian Aboriginal manifestation of the return of the veterans played out on the banks of the Grand River in southern Ontario, on the Six Nations territory. Some newly repatriated Six Nations veterans of the Great War returned home as political agitators. Capitalizing upon both their status as veterans of the Great War inside the Dominion of Canada, and as warriors within the indigenous traditions of warriorship still extant in orthodox Haudenosaunee or Iroquois culture, they used their position to advance their own agenda by deposing the hereditary chiefs. In this sense, they in fact constituted both a political elite, and an ideological special force.

These veterans' adoption of prewar Dehorner ideology coincided with a change in the government's attitude toward the issue. Whereas in the prewar period, the Dominion government was reluctant to interfere, sovereigntist assertions by Six Nations chiefs in 
the postwar period prodded it to change its position. Notwithstanding government's policy of earlier decades premised upon a passive approach of noninvolvement, the postwar conjunction of Dehorner and government interests led to the wholesale removal of the Confederacy Chiefs.

As with the fall of the Romanovs in Russia, and with the passing of the old guard dynasties in other European nations, the demise of the traditional Six Nations Council of Confederacy Chiefs at the Grand River Reserve marked a profound break with a centuries-old past. This break in Iroquois culture and tradition was precipitated by the Great War and by those Grand River veterans who had been most affected by it. It is thus useful to consider that collective experiences gained - and political ideologies and personal philosophies so forged - by events on the Ypres Salient, or on the Somme, could play a role in ousting from formal authority the Council of Hereditary Chiefs of the Six Nations Confederacy of Iroquois. Vance has observed how the ascribed nobility associated with sacrifices made during an epic struggle for a great cause sustained the bereaved during and after the war, and how the postwar image of the Dominion, united in mourning, ultimately provided its citizens with the foundation of the country's collective memory of the war. ${ }^{108}$ Accordingly, so too did the next-of-kin telegrams, the war cemeteries, the monuments to the missing, the overgrown network of trenches, and the honour rolls have a profound effect upon the national psyche and collective consciousness of the Six Nations of the Grand River. Capitalizing fully upon the high profile and elite status accorded them both as warriors within Six Nations traditional culture and as veterans of the Great War within a newly autonomous Dominion of Canada, as will be shown those Six Nations veterans most active within the Dehorner 
movement exploited their position to advance their own agenda for change before both public and government.

A carefully considered information campaign by the Six Nations veterans and their supporters inside government was initiated early in 1919. Letters to the editors of various newspapers, chapters in commemorative volumes, and notices in government publications were used to question the legitimacy of political leadership by traditional hereditary authority, ostensibly while praising the wartime role of Native Canadian troops generally as invaluable martial allies to the Crown and to the Dominion. The complete text of the welcoming address delivered to the returning Six Nations veterans by officials of the Six Nations Soliders Welcome Association was published in the 1919 Annual Archaeological Report for the Province of Ontario. ${ }^{109}$ An article entitled "The Indians and the Great War" appeared in the Brantford Expositor of 22 January 1919. After providing a national overview of Native contributions to Canada's Great War effort, it introduced the thorny issue of political change at Grand River,

There has been some agitation among the Six Nations Indians for a revision of the tribal customs ... The warriors [i.e. the newly returned Six Nations veterans] would remove the custom which limits the choice of chieftanship to the female relatives of a deceased chief. Some of them would have their status as wards of the government or allies of the British crown - and they are both - removed, and free citizenship conferred ... Come what may of the agitation, the Six Nations Indians have played a noble part in the war, and their services are worthy of full recognition. The blood of the Iroquois warriors of 1776 and 1812 ran true in the veins of their descendants in 1914-1918. (LAC, RG 10 Indian Affairs, Volume 3181, File 452,124-1A, Brantford Expositor, January 22, 1919, "The Indians in the Great War").

With the cooperation of selected Six Nations veterans or, in the case of the deceased, their surviving family members, official government publications likewise undertook discussion of the desirability for postwar political change at Grand River. The 
Annual Report of the Department of Indian Affairs for the Year Ended March 31, 1919,

authored by the Department's own Duncan Campbell Scott, noted with respect to Six Nations,

An interesting and impressive function was held at Brantford, where His Royal Highness [the Prince of Wales] unveiled a bronze tablet inscribed with the names of eighty-eight [sic] members of the Six Nations Indians who had given their lives to the Empire in the great war ...The list was headed by the names of Lieutenant Cameron D. Brant, a descendant of Joseph Brant, the great Iroquois leader who assisted the British in 1776, and Lieutenant J.D. Moses, an Indian aviator, who died in a German prison camp as a result of injuries he received when he was brought down over the enemy lines [sic] ... The Indian returned soldiers have been tendered enthusiastic receptions by their countrymen upon their return to the reserves ... The return of so many Indian soldiers who have been broadened and inspired by contact with the outside world and its affairs is bringing about radical and progressive changes in the life of the reserves. (Canada, 1920, 7-8, and 27).

A near-encyclopedic series of postwar commemorative volumes entitled Canada in the Great World War: An Authentic Account of the Military History of Canada From the Earliest Days to the Close of the War of the Nations, by Various Authorities, went into more particular detail concerning postwar conditions at Six Nations. In an appendix to Volume III, again authored by Scott, specific mention is made of the Six Nations veterans' postwar agenda,

The [Confederacy] council ... considers itself as having the status of a sovereign body ... a pretension that the Canadian Government is naturally not disposed to recognize ... Although there is an undoubted charm and interest in the preservation of ancient traditions and customs, their perpetuation in the present instance certainly does not appear to have been in the best interests of the Indians ... It is noteworthy that a new political organization has recently been formed on the reserve, known as the Warriors' Party, which favours the adoption of a democratic system of election for the council. To this group belong the returned soldiers, who have been broadened and educated by experience of the world and its ways; and if they are successful in having their policies adopted by the tribes, a new and more progressive regime may be inaugurated on the reserve. (Scott, 1919, 302-303). 
Scott served as deputy superintendent general of Indian Affairs from 1913 to $1932 .{ }^{110}$ His descriptions of both the wartime services and other contributions of Six Nations band members and their postwar political activities at the forefront of the Dehorner movement provided him the means of promoting both the effectiveness of the branch for which he was responsible, and publicizing its apparent success in accomplishing two of its objectives, namely greater Native participation in the national life of the country, and the replacement of hereditary forms of Native self-government which were widely regarded as incompatible with this first objective. ${ }^{111}$ In the absence of other evidence, however, it is difficult to state to what extent Scott used the platform of the Six Nations veterans in advancing his departmental agenda, or to what extent the Six Nations veterans used Scott's and the department's. As has been shown, prewar the Dominion government was reluctant to involve itself in Six Nations' internal politics, and both Dehorner and Confederacy factions variously invoked or refuted government Indian legislation as it suited their purposes.

In short, the Six Nations troops had not served in a vacuum or in isolation. During wartime their individual and collective actions were reported in the mainstream media as events unfolded. Come peacetime, their surviving numbers were recognized as a specific constituency within the broader returned soldiers' movement. Government officials were aware that the newly returned Six Nations troops had unique grievances pertaining to their legal status as Indians and as Grand River band members. Government was equally aware that the Six Nations veterans enjoyed widespread public recognition of their wartime service, and support for their peacetime political agenda. Finally, government was aware that veterans groups generally were volatile entities whose energies must be 
carefully harnessed to the benefit of the state, rather than to its detriment. ${ }^{12}$ Following the war, the government would come to realize that the objectives of the Six Nations veterans dovetailed with its own.

Mutual aid organizations for the Six Nations troops and their families included the Six Nations Women's Patriotic League and the Six Nations Soldiers Welcome Association. Despite initial reluctance from a portion of the Confederacy Chiefs to endorse what they perceived as an ostentatious welcome to a group which had defied their authority, these two societies with limited cooperation of Council organized a welcoming reception and parade for the newly returned Six Nations troops which was held in the village centre of Ohsweken on Dominion Day, 1919. Sergeant-Major J.W.M. Elliott, an exceptional reform-minded hereditary chief within Confederacy Council who had supported Grand River involvement overseas and who was also the senior noncommissioned officer of the $37^{\text {th }}$ Haldimand Rifles of Canadian Militia, delivered the official welcoming remarks. He spoke of the 300 year tradition of Six Nations military service on behalf of the British Crown, the large number who volunteered, the tragic loss of those who died overseas, and the privations endured by their families at home. His remarks were couched in the prevailing sentiment of the immediate postwar era, and reflected the ideology of those who, having served overseas, as well as their families and supporters at home, had embraced the belief that citizenship within the Dominion and within the Empire was not incompatible with Six Nations band membership. A trace of irony with respect to the war stance of the Confederacy Chiefs was apparent.

We in all honour extend to you the right hand of friendship ... You have most nobly upheld the honour and warlike good name of the Six Nations, and you are the only representatives of us who fought our battles and thereby renewed our 
treaties and compacts with the King, and upheld the good names of our grandsires. (quoted in Orr, 1919, 53-54).

Vance has described the "cult of the service roll" following the War, a phenomenon in which the Six Nations troops fully participated. ${ }^{113}$ A special temporary Six Nations war memorial bearing the names of the dead and missing was erected at Victoria Park in Brantford, and was unveiled by the Prince of Wales on 20 October 1919 during his postwar tour of the Dominion. The official Six Nations Roll of Honour, including the names of all who served, and highlighting those who were subsequently reported killed, died of wounds or illness, missing, wounded, or taken prisoner, appeared in F. Douglas Reville's History of the County of Brant, published in 1920. Memorial plaques were erected at the Mohawk Institute Indian Residential School in Brantford, where many of the Six Nations volunteers had been students, at Her Majesty's Chapel of the Mohawks, and at the numerous small churches located in districts across the reserve. The permanent Six Nations and Mississaugas Indian War Memorial at Veterans Park in the Six Nations village center at Ohsweken would ultimately be unveiled on 12 November 1933, with William C. Johnson, president of the Six Nations Indian War Veterans Association, and Col. Andrew T. Thompson, former officer commanding of the $114^{\text {th }}$ Battalion, presiding. The reform-minded portion of the Six Nations veterans were thus a credible faction with which the Canadian government could ally itself in introducing significant political change at Grand River.

On 1 September 1919, soon after their repatriation to Canada and their return home to the Six Nations Reserve, the surviving Six Nations veterans regrouped in the reserve's village centre of Ohsweken as the Six Nations Indian War Veterans Association 
(SNIWVA). They submitted the following petition to Duncan Campbell Scott, Deputy

Superintendent General for Indian Affairs in Ottawa. Because it states their case

concisely, it is quoted here in full (original spelling, punctuation, and grammar retained):

Ohsweken, Ont.

Sept. 1,1919

To Duncan C. Scott, Esq., Deputy Supt. Gen. of Indian Affairs,

Ottawa, Ont.

Sir.-

We, the undersigned members of the Six Nations Indians, loyal soldiers of H.M. the King, veterans of the World War, of the Township of Tuscarora in the county of Brant do most humbly implore and petition you Sir to hearken and consider our cry for deliverance from our present system of government and hereditary councillorship, and to institute a change whereby we may have a council, elected by, and representative of the people, and we hope and pray that, the "Canada", for which our friends and comrades fought and died, and the same "Canada", we fought and gladly suffered for, may see fit to grant us this change.

For your kind consideration we beg to submit the following reasons.

1. After fighting in France, in the World War for three and four years for democracy and freedom, we return to our own country, and to our own home, and right here confronting us we find one of the most flagrant and shining examples of incompetent autocracy imaginable - our hereditary council - which is, and always will be, an insurmountable obstacle to the progress and advancement of the Six Nations. Not only is it a great handicap but a black stain, in that it had during the Great War, not only proven itself disloyal to Canada and the British Empire, but, an actual hindrance, and block to many who but for it, would also have been with us "Over there." We will just outline a few of the most glaring examples of incompetence, insincerity and disloyalty of our governing body.

(a) When the Duke of Connaught, then Governor General of Canada visited the Six Nations Indians a few years before, and when the war was never dreamt of, our council presented him with an elaborate address professing loyalty, undying faith, readiness to serve the king at any time and under any circumstance etc. etc. A few years passed. England and Canada went to war and recruiting officers were sent among us asking for volunteers. Did our council 
help them? Decidedly no. They did everything in their power to hinder our young men from enlisting in the army of our King and country, and went so far as to institute a quiet campaign against it. We can if necessary name several of the chiefs who were distinctly pro-German, not only at heart but in speech and action.

(b) During the whole time that we were overseas the council did not do one single thing for us or our dependents. Instead of helping to making the lot of our families and ourselves easy to bear, they tried to make us suffer, and this is how they hoped to do it. Our dependents were being supported by the Haldimand County Patriotic Society during the whole time of service, and in 1917 when most of us were in France the Society's funds became low. As a goodly bit was paid to dependents on the reserve the Society most properly asked our Council for assistance. Our council emphatically refused. The Society then threatened to cut off the allowance of the Six Nations dependents unless the Council subscribed. It was no concern of theirs, they again flatly and emphatically refused assistance, and had it not been for a certain missionary who managed to change the decision of the Haldimand County Patriotic Society, our dependents would have been in want and necessity and why? Just because our council wanted to hurt those who dared to enlist in Canada's army without its gracious permission. This is the kind of loyalty, faith and willingness to serve the King, the Six Nations Council shows to-day and why should it remain in power?

(c) The Council of to-day is a large unwieldy body, the dominating faction of which is made up of pagans and their supporters, opposed to everything progressive, disloyal to Canada, ignorant and illiterate. Many of them can not even write their own signature, or speak a word of English. We are ashamed of them, and at the same time sorry for them; and we want to help them as well as ourselves, our children and our children's children out of the rut they have us in and where we will stay so long as we have a hereditary Council at our head. Will the Canada that we fought for desert us? Surely you will stop, listen and help your soldiers up just one step along the path of democracy, progress and industry.

(d) The Council is actively opposed to the Soldier Land Settlement scheme as in operation on our reserve and is doing everything possible to put difficulties in the way of the returned man, and refuses to help us one particle. 
We pray and hope this humble petition will convince you Sir that there ought to be a change and solemnly sign our names below feeling and knowing that Canada will do justice to her soldier sons. (32 signatures) (Canada, 1919).

As the Clanmothers' Petition quoted in the previous chapter concisely and dramatically demonstrates their adherence to the ideology of Six Nations sovereignty, so too does the foregoing Veterans' Petition emphatically convey their notion of allegiance to the Crown in Canada. The Veterans' Petition succinctly states their grievances, and their opinion of continued Confederacy rule during the immediate postwar era. It is apparent overall that the veterans are deeply aware of the historic role that they have played as Six Nations troops in the forces of the British Empire in the Great War just ended, that they grieve the loss of their fallen Grand River comrades and pity their mourning families, and that as a function of their own wartime experiences they perceive no contradiction in being both Six Nations band members and British subjects within an autonomous Dominion of Canada. Their clarity of vision is precise. The veterans in their petition list two circumstances in particular: the refusal of the Confederacy Chiefs to participate in aid toward the soldiers' families' welfare fund (the Haldimand County Patriotic Society); and Council's refusal to support the proposals of the draft Soldier Settlement Act, intended to provide agricultural land to newly returned veterans. In more general terms, the Veterans express disgust with Council's non-endorsement of the Canadian war effort, including recruiting efforts on reserve lands. Their willingness if need be to name "pro-German chiefs" bore witness to the postwar survival of the stigma still associated with any perceived collusion with the enemy, or non-support of the recent 
war effort, and the Six Nations veterans' own internalization of a dominant AngloCanadian bias of that era.

Their previous political activism relative to their stand against the Confederacy Chiefs and Council notwithstanding, the path followed by the majority of the Six Nations veterans was similar to that undertaken by the host of Great War veterans elsewhere across the Dominion: they raised their families, farmed their lands, went about their business, quietly coped with war wounds and mental trauma, and got on with their lives. In the few years immediately following the war, a number of signatories to the petitions of 1917 and 1919 apparently turned their back on Six Nations politics altogether, or actually came to express endorsement of the Confederacy Chiefs in principle. ${ }^{114} \mathrm{~A}$ few of the soldiers later maintained they were not fully aware of the potential impact of what they were signing, one anonymous veteran recalling years afterward,

You know some signed without even knowing what it was about. I don't even think some of them cared. Then, when they came home many turned back. This wasn't surprising since many of them had come from families who'd always supported the chiefs. About fifty percent of them switched back right after the war. (quoted in Weaver, 1975, 426)

Those who remained committed to the cause soldiered on in the fight for representative government. If the assertion made in the quotation above is correct, i.e. that many veterans eventually 'turned back' (expressed a renewed commitment to Confederacy rule) on the basis of family allegiances to the hereditary chiefs, then this would indicate their status as Five Nations band members (Seneca, Cayuga, Onondaga, Oneida, or Mohawk) with guaranteed access to representation in Council under the Great Law. Those remaining committed to the Dehorner cause were likely Tuscarora and Delaware 
band members, that is, non-Five Nations band members with limited voice under the Great Law. In any event, as researcher Kelly McCann notes,

There are thirty-two signatures on the [1919] petition. According to Weaver, twenty-nine of the 292 Six Nations volunteers were killed in combat, five died of illness, and one was reporting missing. Therefore, the petitioners probably represented about one-eighth of the soldiers from the reserve. (McCann, 1994, 24). ${ }^{115}$

Thus even in the immediate postwar era, those returned veterans continuing to manifest Dehorner ideology and advance a reform agenda represented a minority view within the larger body of Six Nations veterans generally. While an absence of direct evidence limits our ability to state the extent to which the veterans were embraced as an esteemed body within Six Nations at the grassroots level, the welcoming remarks given to the veterans by Chief Elliott in his speech quoted above reflects feeling at the official, formal level. These remarks demonstrate that the hereditary chiefs' disapproval of the Six Nations volunteers notwithstanding, the community itself accepted that the veterans' efforts and sacrifices warranted at least some measure of public recognition. At minimum, it appears that the reform-minded Six Nations veterans of the Great War constituted an elite body within the existing Dehorner movement, if not within the broader Grand River community as a whole.

Reference to the Soldier Settlement Act in the 1919 petition is also significant relative to the Delaware band affiliation of many of the veterans, to the extent that from the mid-1800's onward, concomitant with the rise of the Dehorner movement generally, particular Delaware families had emerged as some of the more prosperous farmers on the reserve, and thus presumably amongst those with the greatest vested interest in the retention of Grand River lands for agricultural purposes. 
Following the war, the objectives of the Six Nations Indian War Veterans Association (SNIWVA) often merged with those of the Soldier Settlement Board. The Indian Affairs Branch was responsible for administering the Soldier Settlement Act toward status Indian veterans resident on Indian reserves. Indeed, Elliott Moses, the leading Delaware Dehorner already mentioned, was employed by the Indian Affairs Branch as the Soldier Settlement Board representative on the Six Nations reserve from 1926 onward. ${ }^{116}$ As the son of founding Dehorner Nelson Moses and elder brother to James Moses (deceased) and Arnold Moses (a private in the $107^{\text {th }}$ Pioneer Battalion who survived the war, and was eventually elected band council chief during the 1930's), he did not travel overseas with the original $114^{\text {th }}$ Battalion but remained on-reserve to manage the Moses family farm on the reserve's Third Line concession (locally still called "Delaware line"), meanwhile remaining active as a commissioned militia officer in the $37^{\text {th }}$ Haldimand Rifles throughout the war. It is also relevant to note that it was in regard to tensions arising from some Confederacy Chiefs' reluctance to make facilities on the reserve available for use by agricultural workshops related to implementation of the Soldier Settlement Act, that Duncan Campbell Scott first speculated that the newly returned Six Nations Veterans might renew their Dehorner agitation upon their arrival home. On 30 May 1919, Scott noted in a communiqué to Arthur Meighen, then minister responsible for the Indian Affairs Branch,

They [Confederacy Council] are almost invariably opposed to measures undertaken by the Department with a view to benefiting the Indians of the Reserve. I am of the opinion that the only solution of the problem is an elective council. Many of the more advanced Indians have expressed themselves in favour of an elective system, and I think the scheme will receive the endorsation [sic] of the Indian soldiers upon their return. (quoted in Weaver, 1975, 384). 
The previous chapter has shown that the era of the Great War and its attendant tensions coincided with the passing within Confederacy Council of moderate voices like John Arthur Gibson and Josiah Hill. Concomitantly a handful of Six Nations sovereigntists became entrenched within Council and had emerged by the early 1920 's to advocate the cause of Six Nations independence before an international audience. Principal among these were Chauncey Garlow and the charismatic Deskaheh, who had been installed by his clanmother as one of 10 Cayuga hereditary chiefs in 1917. At Deskaheh's prompting, Canadian lawyers A.G. Chisholm and W.D. Lighthall were hired using band funds between 1919 and 1921 to press what had become known as the "Six Nations status case" before the Department of Justice. ${ }^{117}$ Having made no progress after two years in pressing their claim before the Dominion government for nothing less than Canadian recognition of the sovereign status of the Six Nations of the Grand River, the Chiefs terminated the services of these two lawyers in April 1921. Deskaheh soon retained the services of an American lawyer from Rochester, New York, named George T. Decker. ${ }^{118}$

Rather than dealing with the Six Nations status case domestically, Decker proposed a different approach that involved approaching foreign governments, and ultimately the League of Nations. Deskaheh traveled to England during the summer of 1921 in order to hand deliver a petition to King George V. He got as far as Winston Churchill, then Secretary of State for the Colonies, who could only advise that the matter was within the exclusive jurisdiction of the government of Canada. ${ }^{119}$ In December 1922, with a view toward having the Dutch present their claim for them before the League of Nations, the Chiefs sent to the embassy of the Netherlands in Washington DC a memorial 
in which they indicated the Six Nations Confederacy had exhausted every peaceful means in attempting to obtain redress of their grievances against the Canadian government, and furthermore stated that,

Hostility now exists between us and the Canadians, and war between us, defensive only on our part, threatens and imperils the relations between us and Canada destructive of the peace and good understanding which has long existed between us. (quoted in Weaver, 1975, 447).

The official Canadian response to this document was a communication direct from Canada's Under-Secretary of State for External Affairs, Joseph Pope, to the Secretary-

General of the League of Nations. It bluntly stated,

The claim that the Six Nations are an organized and self-governing people so as to form a political unit apart from Canada, is to anyone acquainted with the actual conditions, an absurd one. The position of the Indians as British subjects resident for a long period of years within the unquestioned jurisdiction and recognized boundaries of Canada, subject to and protected by Canadian laws, is matter of public knowledge ... It may be added that in the dispute with the Indians, no military force has been employed ... The Canadian government accordingly desires to protest against the Netherlands' government's action in bringing a controversy between the Canadian government and individuals owing it allegiance, which is entirely of domestic concern, to the notice of the League of Nations. (quoted in Weaver, 1975, 452-453).

Finally in 1923 Deskaheh and Decker traveled to Geneva themselves and attempted to state the case for Six Nations eligibility for membership in, and thus status as a sovereign independent nation, before the League of Nations. An extract from Deskaheh's address “The Redman's Appeal for Justice” drafted by Decker, reads,

The Grand River people have never yielded their sovereignty by any formal abandonment of it, and they have never been conquered in war by any power on earth of which there is either record or tradition. They are by right a sovereign and independent Nation or State. (quoted in Weaver, 1975, 416).

And further, 
... the Six Nations of Iroquois, being a state within the purview and meaning of Article 17 of the Covenant of the League of Nations, but not being at present a member of the League ... crave therefore invitation to accept the obligations of Membership of the League ... (quoted in Rostkowski, 1995, 2).

The sovereigntists had been inspired by the League's own "spirit of Geneva" ideology, which embraced the autonomy of small nations, the recognition of new states, and the rise of a new global political order. ${ }^{120}$ In addition to the Dutch who had originally advanced their claim, Deskaheh and Decker were at least initially successful in obtaining the endorsement of a select group of other League member states including Estonia, Panama, Persia, and the Irish Republic, to press for a hearing of their case before the League. Their efforts were handicapped, however, at the point it became evident that the Iroquois nationalism they were advocating was stridently ethnic in tone. The "spirit of Geneva" ethos notwithstanding, such an unabashedly ethnic nationalist ideology was counter to the prevailing mood of the League wherein the predominating sentiment placed greater store in civil conceptions of the cosmopolitan nation-state with democratically elected leadership, rather than traditional hereditary authority providing the mandate to govern within homogenous racial or ethnic enclaves. ${ }^{121}$ The Six Nations claim stridently proclaimed them as a unique people, forever separate on the basis of their unique ethnic and national features. ${ }^{122}$ Support for the sovereigntists' platform soon waned in view of such a stance, and in consideration of the various refutations put forward by the British and Canadian governments. Ultimately various procedural delays, and continued lobbying by both the British and Canadian delegations, prevented the matter from being formally presented before the League's General Assembly. ${ }^{123}$ By May 
1924 it is evident that the matter had been dropped entirely for any serious consideration by the League, it having been determined that the case was purely a domestic issue pertinent to the Dominion of Canada, and one upon which the world body had no mandate to intrude. ${ }^{124}$

Although ultimately unsuccessful, Deskaheh's activities were an obvious embarrassment to the Canadian government, which having just received an increased measure of its own autonomy as a function of its Great War participation was unwilling to entertain the notion of any competing sovereignties on Canadian soil. Although Canada had entered the Great War as a subservient colony within the British Empire, by virtue of its wartime investment of manpower and other resources it had emerged with an increased measure of independence as demonstrated by its presence as a separate delegation to the Paris Peace Conference, its capacity to sign the resultant Treaty of Versailles as a separate national entity, and its membership in international bodies including the League of Nations and the International Labour Organization. During the years immediately following the war, however, this newfound independence remained tenuous and in many respects it rested awkwardly upon the shoulders of the Canadian state. Canada did not have a fully autonomous foreign policy with diplomatic representatives posted abroad in other countries until several years afterward, and not until the Statute of Westminster in 1931 would Canada achieve a status within the British Commonwealth providing it parity with Great Britain itself. ${ }^{125}$ Margaret MacMillan has described Canada's gradual transition toward autonomy during this era as muted, slow, and tentative. ${ }^{126}$ 
Deskaheh's presence on the international scene as a strident indigenous nationalist advocating the independence of an autonomous Iroquois homeland enclaved in the heart of the Canadian dominion contradicted Canadian assertions of its own sovereignty. The optics were not useful to the Canadian cause in enlarging the sphere of its own influence on the world stage: what nation-state could convincingly assert its own sovereignty while an apparently well organized portion of its own Aboriginal population actively challenged that very sovereignty before the same court of world public opinion? Additionally, Deskaheh's activities were an annoyance to other Six Nations leaders themselves. Asa R. Hill, secretary to the Confederacy Chiefs, called Deskaheh an agitator with no interest in coming to any understanding with his political foes, and expressed fears that his actions would end Confederacy rule; while Federick Ogilvie Loft, another Six Nations commissioned officer veteran and founder of the League of Indians of Canada, wrote to Prime Minister Mackenzie King that Deskaheh was acting as a dictator, enjoyed no position superior to any other chief within Council, and indeed, had received no mandate at all from any portion the Six Nations people to act as he did. ${ }^{127}$

In a succinct refutation of key points in Deskaheh's claim of Six Nations sovereignty posited before the League of Nations, the Department of Indian Affairs, on behalf of the Canadian government, stated on 27 December 1923,

The Six Nations are not now, and have not been for many centuries, a recognized or self-governing people but are, as aforesaid, subjects of the British Crown residing within the Dominion of Canada. The statement that the Six Nations have treated with the Dominion of Canada is incorrect. The Dominion of Canada has at no time entered into any treaty with the Six Nations, or recognized them as having any separate or sovereign rights ... it may be pointed out that the various Acts of the Imperial Parliament establishing successive measures of autonomy in Canada ... do not exclude the Six Nations or their reserve lands or treat them in any way otherwise peculiar. (quoted in Meijer Drees, 1995, 86-87). 
In fact, Six Nations claims to sovereignty had been examined and considered in detail by

Crown and colonial, and eventually Dominion officials, upon numerous occasions, virtually from the time of the founding of the Six Nations of the Grand River territory in 1784. In 1797, Peter Russell, colonial administrator for Upper Canada, advised in a communiqué to London,

The Instrument given to the Six Nations by Sir F. Haldimand [the Haldimand Deed] clearly permits them only to live on this Land, they and their posterity for ever; consequently the Property as well as the sovereignty of it still remains in the King ... (quoted in Hagopian, 1997, 321).

Writing in 1839, Mr. Justice Macauley found that,

[T] he resident tribes [on the Grand River] ... being in point of fact naturalized or natural born subjects, and domiciled within the organized portion of the Province, it would be difficult to point out any tenable grounds on which a claim to an exempt or distinctive character [i.e. a sovereign status] could be rested. The Six Nations have, I believe, asserted the highest pretensions to separate nationality but in the courts of justice they have been always held amenable to ... the laws of the land. (quoted in Montgomery, 1963, 96-97).

An 1890 response by the Dominion government to a petition by the Confederacy Chiefs reiterated,

The Superintendent General of Indian Affairs is unable to concur in the view put forward in the petition [that the Six Nations Confederacy is sovereign] and he is of the opinion that there is no ground on which the same can be supported ... the Government ... cannot sanction or hold as valid the claim put forth in the petition, on behalf of the Six Nations Indians, to special exemption from the effect of the laws of the land, nor that community being recognized as other than subjects of Her Majesty the Queen.. (Ibid, 96).

In April, 1912, on the eve of the Great War and in response to a petition from the Confederacy Chiefs received that February, the Hon. R. Rogers, Superintendent General for Indian Affairs, reiterated the stance of the Dominion government relative to the notion 
of Six Nations sovereignty. In this instance it is worth noting that while dismissing the notion of sovereignty, the government still maintained its policy of non-involvement in internal Six Nations politics,

The system under which the Six Nations chiefs are chosen and appointed has survived from the earliest time and it should not be the policy of the Government to endeavour to alter this system of hereditary chieftanships so long as ... it promotes good government ... I may remark that as Canadians we are endeavouring to build up a nation under the British flag, and I cannot imagine any greater destiny for the Six Nations than to take part in this general patriotic movement. If you separate yourselves from it your aims will become narrow and your activities will be restricted. I would, therefore, suggest that your aim should be to attain British citizenship. It may be years before you enjoy that in its fullest degree, but it seems to me this is the destiny towards which the best interests of your nation point. (quoted in Weaver, 1975, 362-365).

Immediately after the war, a legal opinion by the Department of Justice dated 1

September 1920 found that,

[I]t would be a hopeless project for the Six Nations Indians to endeavour to judicially establish before the Supreme Court ... that they constitute an independent, or quasi-independent, nation or that in any respect ...they are not subject to the legislative authority of the Dominion, or of the Province of Ontario in matters in which it is competent for the Province to legislate upon respecting the property or rights of Indians. (quoted in Montgomery, 1963, 97).

Whether discussing Joseph Brant's or Deskaheh's efforts to assert Grand River sovereignty, it is well established under the law of nations that practice and policy regarding sovereignty and title, although originally developed by European legal thinkers and arising from within the Western legal tradition, have been adopted the world over by all peoples and states. Further, newly developed legal concepts cannot be applied retroactively to dispense with rights previously entrenched under earlier standards. ${ }^{128}$ These remain fundamental principles of universal application in international law. In essence, the Six Nations' own notion of sovereignty remains irrelevant under the law of 
nations, it being a firmly established principle in international relations that the law which applies in a territory is the law of that society which effectively controls that territory to the exclusion of all others. ${ }^{129}$

In short, in considering both Brant's and Deskaheh's claims of Iroquois sovereignty, one must conclude that the Six Nations were merely occupants on British lands which the Crown had acquired from the Mississauga under the principles and procedures stipulated in the Royal Proclamation, and which at the time had been specifically introduced to establish British hegemony in North America. The Six Nations' leadership acknowledged Crown sovereignty and extinguished their own to the extent that they ever accepted a land grant from the British, and in subsequent dealings with colonial authorities they routinely provided tacit acknowledgement of the authority of the Indian Department to promulgate Indian policy and interpret Indian legislation on a regular basis. Unlike the American colonies which pursued a sustained political campaign and finally resorted to insurgency and armed resistance to challenge British rule in North America, the Six Nations never offered such a dramatic repudiation of Crown sovereignty. ${ }^{130}$ On the contrary, the majority of the Six Nations had fought for the continuity of Crown rule during the Seven Years' War, the American Revolution, the War of 1812 , and during the Rebellions of $1837-38$, not to mention of course the Great War.

Their petition of 1 September 1919 and other aspects of their information campaign as previously described notwithstanding, throughout the early 1920's the SNIWVA remained practically silent as Deskaheh and his supporters mounted their campaign abroad. Tracing the activities of the SNIWVA from 1920 to 1924 is difficult: 
the present-day Six Nations Veterans Association has no archive, and the Confederacy Chiefs kept no records concerning the activities of their principal opponents during this era. Indian Affairs Branch records concerning SNIWVA activities at this time have either been lost, destroyed, or were never kept to begin with. What records are available, however, do suggest a certain interpretation. On the basis of the available evidence (the 1917 Soldiers' Petition, the 1919 Veterans' Petition, the Indian Affairs annual report for the year ending 31 March 1919, the D.C. Scott chapter appearing in Canada in the Great World War, the various newspaper articles referred to, and mention of the returned soldiers in the Commissioner's Report described below) it seems likely that this silence of the SNIWVA during 1920 to 1924 was intentional. The veterans had stated their grievances and their proposed remedy concisely in their 1917 and 1919 petitions. Given the mood of postwar Canadian society and the state of international relations fostered by the League of Nations, the veterans had considerable political capital. Following this the veterans needed only to withdraw discreetly from the public eye for a period of time as Deskaheh continued his activities overseas, and alienated the cause of Iroquois sovereignty ever further from Dominion, British, and international consideration. Unlike the sovereigntists, the Six Nations veterans had no need to travel to Europe to demonstrate their values and convictions before an international audience - they had already done so during 1914-1918. Ultimately, the appointment of two government officials provided the veterans' cause with greater potential advantage than could ever have been achieved by more overt means. Following the government of Canada's statement on the Six Nations sovereignty issue, on 20 March 1923 Indian Affairs Deputy Superintendent General D.C. Scott appointed Col. Andrew Thompson to head a special 
commission to investigate political conditions on the reserve. Col. Cecil E. Morgan was appointed Indian Affairs branch superintendent to the Six Nations Indian Agency at Brantford in October 1923, following the conclusion of Thompson's formal investigation. ${ }^{131}$

Morgan was a Boer War veteran and a former British colonial administrator with experience in South Africa. ${ }^{132}$ Remarkable for his gruff manner, military demeanour, and habit of wearing a sidearm, he was a man with whom many of the reform-minded Six Nations veterans could identify. Thompson meanwhile was the former commanding officer of the $114^{\text {th }}$ Battalion, and a strong advocate on behalf of the Six Nations veterans generally. ${ }^{133}$ During the early twenties a number of events transpired on the reserve that, in association with Deskaheh's activities overseas, served to render the split between the Dominion and Confederacy governments as final. Three circumstances in particular - the posting of an RCMP detachment on the reserve in January 1923 in response to a reported increase in the bootleg liquor trade, a proposed Indian Act amendment perceived as bolstering the authority of the Indian Affairs Branch to enact compulsory enfranchisement against band members, and finally the provision to Indian Affairs Branch of the authority to administer the Soldier Settlement Act for status Indian soldier settlers on reserve lands - alienated the Chiefs further while apparently increasing federal authority over the affairs of the Six Nations. ${ }^{134}$ Within this context neither Morgan's appointment as superintendent nor Thompson's appointment as investigating commissioner can in any way be construed as impartial. The Confederacy Chiefs and their supporters subsequently boycotted the hearings Thompson convened as he gathered evidence for his report. ${ }^{135}$ Here was the man who had been commanding officer of the 
$114^{\text {th }}$ Battalion from shortly after its formation until its disbanding in England in the autumn of 1916. While the battalion never saw action as a unit, Thompson was the man who personally signed the attestation papers of many of the Six Nations troops, oversaw their basic and advanced infantry training, led them overseas, and once in England, saw the troops off as they departed for their various combat units at the Front. Although himself an Ottawa resident when the war began, the Thompson family had been prominent in the Grand River valley for three generations and had been investors in the failed Grand River Navigation Company enterprise. Their neoclassical-style family estate called Ruthven, near Cayuga, was visited frequently by leading Six Nations Dehorner families and their supporters throughout the late $19^{\text {th }}$ century.

Thompson submitted his report late in 1923. His findings on the matter of Six Nations governance were concise,

(1) The people as a whole have no voice in the selection of their councilors.

(2) The present Council is absolutely unwieldly [sic]. It consists of some sixty chiefs, charged with the conduct of the business of less than five thousand people. This leads to great delay in the transaction of even simple matters.

(3) Owing to the method of appointment a great many of the chiefs are ignorant men. Many of them are unable even to read and write, and totally incapable of transacting business.

(4) The present Council is unnecessarily expensive. An expense allowance is made to each chief for attendance at Council meetings, and while the individual payment is not large, the aggregate is staid to amount to at least $\$ 1,000$ per annum.

I am convinced that those advocating a change in the system of government have fully established their contention, and that an elective system should be inaugurated at the earliest possible date. (Canada, 1924, 12). 
Based on Thompson's findings, and notwithstanding its previous policy of noninvolvement from the 1860's onward in Six Nations governance issues, the federal government through the Department of Indian Affairs, intervened decisively in 1924 to support the Dehorners, and their military wing, the returned Six Nations veterans, in the withdrawal of Canadian recognition of the traditional Council of Confederacy Chiefs as the official governing body of the Six Nations of the Grand River. In its place was instituted an elected band council government, as per the terms of the Indian Act. By an Order-in-Council dated 17 September 1924 the reserve was divided into six electoral districts, each of which was represented by two councilors, with the 12 councilors so elected voting among themselves to designate one of their number as chief councilor. The first election was held on 21 October $1924 .{ }^{136}$ Three of the first twelve elected councilors, Lt. Frank Montour, and Sappers Joseph Hill and Welby Davis, were veterans. Another veteran, William F. Powless, was appointed Secretary to council. ${ }^{137}$

By 27 November 1924, the Department of External Affairs, in the Canadian government's final communication to the League of Nations on the Six Nations sovereignty issue, could state,

[T] hat the recommendation of the Commissioner in regard to the elective system of the Six Nations has already been put into effect, and that on the $17^{\text {th }}$ September, 1924, an Order-in-Council was passed applying the election provisions of part two of the Indian Act. An election was held on the $21^{\text {st }}$ October, 1924, and the new elected Council is now in office having replaced the former hereditary body. It is believed that this change to a more modern political system will have a good influence on the reserve and act as a stimulation to progress and advancement among the Six Nations. (quoted in Meijer Drees, 1995, 88).

In the decades following, up into the 1960's, many Six Nations veterans of the Great War remained active in band council government. During the ensuing decades the 
veterans as a group maintained close ties of comradeship by virtue of their shared wartime experiences overseas, despite sometimes differing political allegiances at home. ${ }^{138}$ Since 1924 voter participation has ranged from 20 to 40 per cent turnout of eligible voters. ${ }^{139}$ This low-to-moderate turnout reflects a combination of voter apathy by some, and a continued allegiance to the hereditary system by others. In any event, Six Nations veterans of the Great War had established their contention: they had introduced the notion of one band member, one vote, in the selection of political leadership on the Six Nations of the Grand River Reserve. The last of their number to pass away was their lone female member, Edith Anderson Monture, the nurse who had served with the American Expeditionary Force. She died in her sleep at Six Nations in April, 1996, ten days shy of her $106^{\text {th }}$ birthday.

In summary, Thompson's appointment as commissioner and Morgan's appointment as superintendent may be seen as an indication of the extremely dim view taken by the Dominion government of the Six Nations sovereigntist movement during the immediate postwar era. Whereas in previous decades the Dominion government was satisfied if not eager to see Grand River administration continue under the hereditary council of Confederacy Chiefs, in view of their renewed postwar sovereigntist efforts under Deskaheh before international bodies, the Dominion government was finally convinced to intervene dramatically in Six Nations affairs, and to terminate the rule of the Chiefs and clanmothers. It thus appears that the veterans' campaign, combined with postwar Canadian sensitivities concerning its own newly found independence, created a combination of factors which compelled the government to intervene in disposing of an irksome issue relative to internal governance at Six Nations. 
As Dehorner historian Elliott Moses summarized a somewhat simplified chain of events in the late 1960 's,

When the Council's actions [i.e. non-support of the Six Nations troops and their families] became known to the soldiers on the battlefield, their officers circulated a petition amongst the boys which was eventually forwarded to the Canadian Federal Government asking that the Council be disposed of for the action taken against them. No action was taken until after the close of the war when a Royal Commissioner [Thompson] was appointed to investigate the whole situation. He considered years of complaints by the progressive element of the Reserve, the soldiers' petitions, and the refusal of the Council to co-operate with the Federal Indian Affairs Branch ... By proclamation in the year 1924, the government disposed of the old Hereditary Council and inaugurated an elective system of council. (Moses, 1968, 24).

Other local histories appearing at Grand River around this time likewise assign responsibility for the 1924 deposition of the Confederacy Chiefs to the actions of the returned soldiers in assuming leadership of the Dehorner movement,

A movement of so-called "Progressives" sprang up to change all this. Led by the three hundred returned men from the overseas trenches, the progressives set out to dehorn the chiefs. Previously, a petition had come from those trenches duly censored, signed by these soldiers in France, demanding a more modern, democratic form of council. There was much bitterness, and the Six Nations Reserve was split right down the centre. The Progressives called the die-hards a backward element ... the Mohawk Workers accused the dehorners of selling their people down the river. (Montour, 1973, 126).

The veterans' petition submitted to Ottawa in 1919 signaled to both the Dominion government and the Confederacy Chiefs their intention to continue the Dehorner struggle in deposing the Chiefs in favour of band council elections. Statements of their agenda in newspapers and other publications brought their cause before a public audience. Their actions in presenting their vision for change before public, government and Confederacy audiences reveals the work of an organized movement with a specific political objective, as does their subsequent decision to remain silent as Deskaheh forged ahead with his 
overseas campaign to have the League of Nations grant recognition of Iroquois sovereignty. Unfortunately for the Six Nations sovereignty movement, Canada continued to enjoy a high profile within international relations given its recent showing in the Great War, while Deskaheh's articulation of a stridently ethnic Iroquois nationalism was at odds with the spirit and intent of the League of Nations mandate which placed a higher premium on civic formulations of the nation-state. Surviving elements of the Six Nations troops had assumed leadership of the Dehorner movement following the Great War, and actively colluded with a Dominion government eager to placate militant veterans. The first band council elections accordingly took place in 1924. 


\section{Summary and Conclusions: The Sovereignty Question}

There was a long history of organized opposition to the traditional form of government on the Six Nations of the Grand River Reserve, from among a portion of band members themselves. The political change finally occurring in 1924 was thus neither an arbitrary nor unilateral intervention of the federal government. The adoption of Dehorner ideology by Six Nations troops of the Canadian Expeditionary Force (eventually Dominion veterans of the Great War), and increasingly strident declarations of sovereignty by the Confederacy Chiefs and their supporters, were the final acts in persuading the federal government to intervene decisively in deposing the Chiefs and implementing elected band council government. Having itself just received increased autonomy within the British Empire as a function of its participation in the Allied Great War effort, the Dominion of Canada was disinclined to entertain the notion of a competing sovereignty within its recognized boundaries. When such a challenge arose from the traditional council of hereditary chiefs of the Six Nations of the Grand River, Canada acted swiftly in common cause with those band members - including the Six Nations veterans - advocating the application of an elected system within parameters set by federal legislation.

The question of Six Nations sovereignty had been decided in the negative by imperial, colonial, and ultimately Dominion officials, on numerous occasions from during Joseph Brant's own lifetime, into the $20^{\text {th }}$ century. Findings in each instance had been duly conveyed to the appropriate Six Nations leadership of the era. While perhaps never specifically subjugated in a military sense (although one could argue such a defeat at arms had occurred, to the extent the majority of the Six Nations Confederacy supported 
the losing side during the America Revolution), neither did the Six Nations themselves ever successfully repudiate assertions of Crown or Dominion sovereignty by political, legal, or diplomatic means, as is the required standard under the system of international law which the Six Nations sovereigntists presumed to invoke. That the formal authority of the hereditary system of Confederacy Chiefs at Grand River was being challenged internally and externally is apparent by the start of the 19th century, in view of the recognition granted by the Crown to non-hereditary leaders such as Joseph Brant and his hand-picked successor John Norton, and in view of the apparent inability of the traditional leadership to repudiate this and reassert its own authority.

The Dehorners emerged by 1861 as an organized reform movement to oust the hereditary council of Six Nations Confederacy Chiefs and implement elected band councils, precisely because during the first half of the nineteenth century the Grand River land base had been steadily eroded while under the administration of the Confederacy Chiefs. These Dehorners consisted mainly of Delaware, Tuscarora, and other disenfranchised Grand River band members (including Tutelo, Nanticoke, and others) who saw no likelihood of influencing decision-making processes within the traditional structure of the hereditary Council of Confederacy Chiefs, insofar as the Six Nations constitution, the Great Law, vested the greatest decision-making power with representatives of the five founding nations: the Seneca, Cayuga, Onondaga, Oneida, and Mohawk. Colonial and subsequent Dominion governments were not inclined to intervene on behalf of the Dehorners and terminate the mandate of the Confederacy Chiefs, because under the Chiefs' administration the Grand River land base continued to disappear into non-Native hands, which suited the surrounding white settlers, entrepreneurs, and land 
speculators, and the policy thrust of Upper Canadian and later federal administrations. During the late 1800's and early 1900's a conciliatory element within the Confederacy Chiefs attempted to accommodate the Dehorners by designating a number of them as pine tree chiefs, and by appointing others to various boards and commissions within Council. However, this was never enough to placate the Dehorners: such appointments occurred in haphazard fashion, was a process which itself was open to abuse, and did not address the underlying problem: the Great Law contained no amending formula that would permit the provision of a full and equal voice within Council to non-Five Nations band members.

In 1914 the sovereigntist stance of diplomatic neutrality asserted by the Confederacy Chiefs in relation to the Dominion's Great War military effort offended both the federal government and that sizable portion of Grand River's male population of military age which was eager to participate in the War, and thus acquire coveted warrior status in accordance with Haudenosaunee cultural norms. The positive response by some three hundred Six Nations band members to a call-to-arms from the Dominion of Canada and the British Empire was in itself a challenge to the authority of the Confederacy Chiefs. By 1917 the Confederacy Chiefs' refusal to endorse the military service of their serving band members, and to ameliorate the lot of their families at home, further alienated the soldiers, their families, and their supporters, who by this point included both the Dominion government and the general public. Postwar, the increasingly strident sovereigntist element under the charismatic leadership of Deskaheh began to embarrass the Dominion government internationally by advocating Six Nations independence before the League of Nations, and other world bodies. By 1924 the Six Nations 
sovereignty movement had become a major irritant to the Dominion government, to the extent that it was finally willing to intervene decisively with the Dehorners and the Six Nations veterans, to oust the Council of Confederacy Chiefs, and introduce elected band council government. Final attempts to secure international recognition of Six Nations sovereignty before the League of Nations were unsuccessful because the sovereigntist cause was premised upon an ethnic nationalism that was counter to the prevailing values of the League, and because, in terms of realpolitik, continued support of the Iroquois platform would have placed potentially sympathetic post-colonial states, each facing their own challenges relative to their respective ethnic or national minorities, in conflict with the Dominion of Canada, newly emergent on the world stage.

Finally, in view of their proportionally small numbers within the Six Nations population as a whole, the drastic nature of their goal to dispense with the Confederacy Chiefs altogether, and their willingness to accept Indian Act administration under federal jurisdiction, the veterans' reform agenda cannot be seen as representative of a grassroots community consensus. Neither, however, were the Confederacy Chiefs the political representatives of a sovereign people, nation, or state, recognizable as such under international law. This is not to say unequivocally that Six Nations sovereignty does not exist. Rather, if it does, future assertions of such sovereignty will have to find support in sources other than international law, or Canadian constitutional law. Probably nothing less than a unilateral declaration of independence, backed by the military and other infrastructure necessary to give full force to such a dramatic assertion, would be required to assert Six Nations sovereignty. 


\section{Endnotes}

\footnotetext{
${ }^{1}$ See Shimony (1961), 91 for a conventional interpretation of Six Nations factionalism immediately following the First World War and leading to the events of 1924. As she put it,
} There had long been a struggle between the hereditary, or "peace" chiefs, and the "warriors" (then in the guise of World War 1 veterans and other acculturated personnel on the Reserve, who wished the Reserve to be as similar to the surrounding Canadian townships as possible) ... When the Indian Department perceived that there was local unrest and an indigenous desire to abolish the system of chiefs ... it is not beyond suspicion that the government ... thought that an auspicious time for action had arrived and that such action would not be unilaterally an imposition of the Canadian government.

${ }^{2}$ See Bercuson \& Granatstein (1992), 86, entry for "Great War Veterans Association"; and Ibid, 176-177, entry for "Returned Soldiers, World War I".

${ }^{3}$ See Abercrombie, Hill and Turner (1994) 138-139, for the four features attributed to an elite in sociology: small numbers, special status, incomplete integration within the mainstream, and the ability to impose will despite these limits.

${ }^{4}$ See Weaver (1975), 124 concerning the number of signatories to the 1861 petition, and Weaver (1975), 326,381 , and 387 concerning the 1907,1917 , and 1919 petitions respectively.

${ }^{5}$ Canada (1913), 182.

${ }^{6}$ This working definition is inspired by an explanation and discussion appearing in Abercrombie, Hill and Turner, 1994, 206-207.

${ }^{7}$ See Evans \& Newnham (1998), 512-513, entry for "State".

${ }^{8}$ Cited in Hagopian (1997) at p. 312, Michael Simon has posited the view that the Haldimand Deed may be interpreted as having created an independent Iroquois state in North America.

${ }^{9}$ Witness two recent anthologies of Canadian military historical writing, Canada and the First World War: Essays in Honour of Robert Craig Brown, David Mackenzie, Ed., and Canada and the Great War $\sim$ The Western Front Association Papers, Briton C. Busch, Ed.

${ }^{10}$ See Benincasa (1994) and Trevithick (1998).

${ }^{11}$ It remains unclear at what point an aspiration toward political sovereignty as a core Iroquois cultural value first appears in the literature. See Noon (1949), 22, for a listing of key terms identified by Smithsonian Institution anthropologist J.N.B Hewitt (himself a Tuscarora descendant) in 1920 as expressing core Iroquois or Haudenosaunee cultural values. These include $\mathrm{Ne}$ 'Skenno (meaning sanity of mind and health of body, as well as peace between individuals and groups); Ne 'Gaii'hwiyo (meaning righteousness and equity); and $\mathrm{Ne}$ 'Gas 'hasde (referring both to physical strength and ritual power). See Monture-Angus (1999), 36, for an explanation of the Mohawk word tewatatha:wi' (meaning "we carry ourselves") as a Mohawk equivalent to the European notion of sovereignty. See Alfred (1999), xxiii, for a re-working of the peace, power and righteousness themes first articulated by Hewitt, as providing a structure for his own work. The presumption amongst each of these writers is that political sovereignty is the ambition of every group of people seeking recognition among other groups of people.

${ }^{12}$ Moses (2007), "The Return of the Native: Six Nations Veterans and Political Change at the Grand River Reserve, 1917-1924", chapter 5 in Lackenbauer, P. Whitney and Craig Leslie Mantle, Eds. Aboriginal Peoples and the Canadian Military: Historical Perspectives, Kingston: Canadian Defence Academy Press, 117-128.

${ }^{13}$ See chapter 3, "Settlement and Land Policy", 124-144 in Craig (1963), and part D, "The White Man's Frontier", 120-192 in Johnston (1964), respectively, for policies, practices and attitudes pertaining to land throughout Upper Canada and in the Grand River country during the time period approximating 1784 to 1841 .

${ }^{14}$ While this thesis focuses on the actions of a dissident minority of Six Nations band members which agitated for the removal of the Confederacy Chiefs, this is not to imply that the Confederacy Chiefs and their supporters remained silent at the time of their removal in 1924 or during ensuing decades. See Titley (1986), 127-134 for a description of continued sovereigntist activity by Confederacy Chiefs and their supporters during the 1920's and 30's, and Cork (1962), 4-13 for a description of the Ohsweken Council House "coup" and takeover of 5-13 March 1959. 


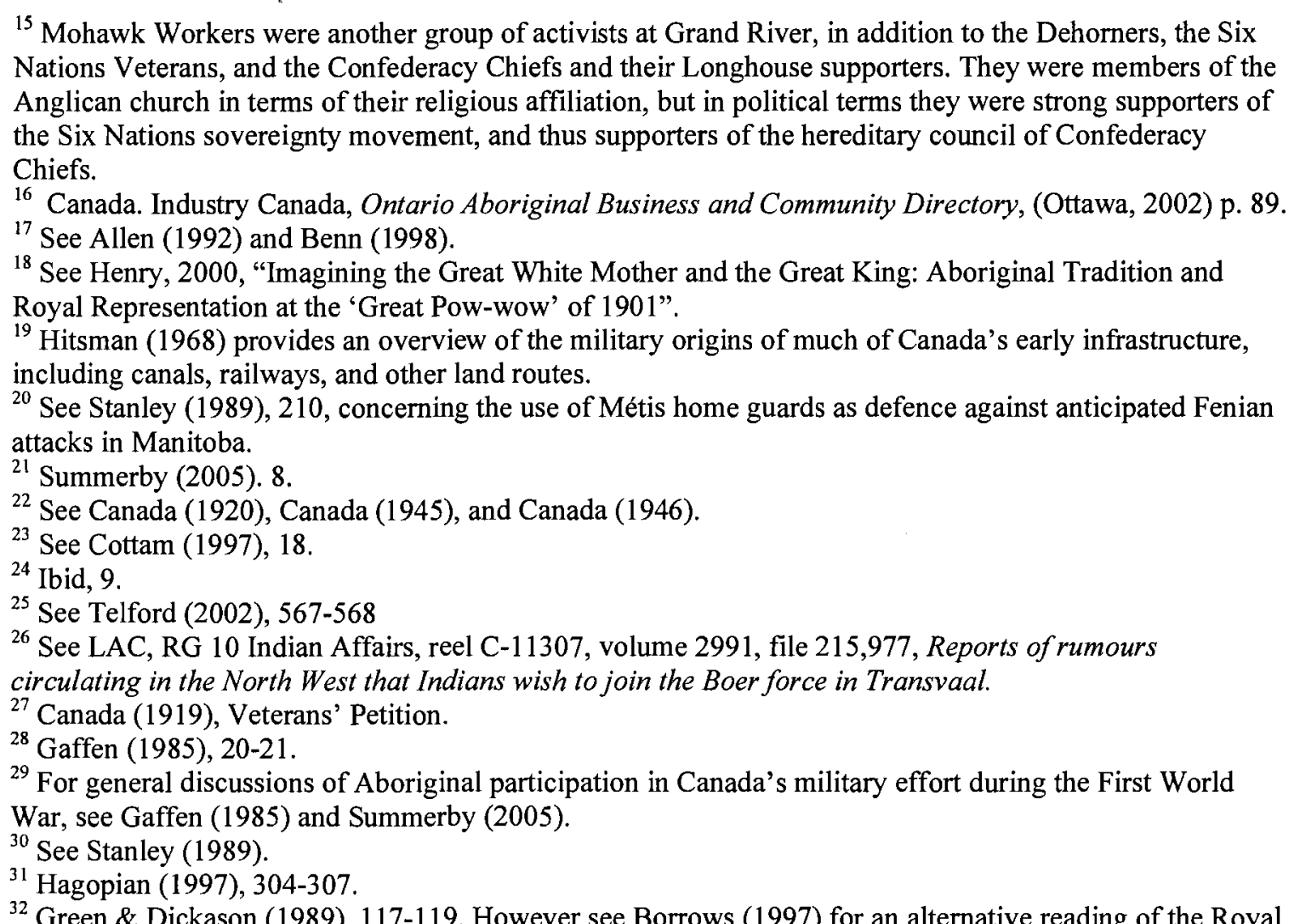
Green \& Dickason (1989), 117-119. However see Borrows (1997) for an alternative reading of the Royal July/August, 1764 was in fact convened to provide Native ratification of the principles of Aboriginal selfgovernment implicit within the Royal Proclamation, and that together the Royal Proclamation of 1763 and the ratification provided at Niagara in 1764 constitute a treaty.

${ }^{33}$ Harring (1998), 18 and 32-33.

${ }^{34}$ Lackenbauer (2007), 7-9 and see 261: "To essentialize Aboriginal-government relationships as a perpetual chain of oppression appears to be superficial, misleading and, in some case, ahistorical." ${ }^{35}$ See Titley (1986), 13. An 1880 amendment to the Indian Act placed the Indian Affairs branch under the direction of the Minister of the Interior, within which portfolio it was considered a "minor component".

${ }^{36}$ Ibid, 13. In the early 1880's, the headquarters staff of the Indian Affairs branch in Ottawa numbered less than 40 persons, most of these file clerks, typists, and copyists. The network of Indian agents in the field and their support staff numbered 460 in 1890, far fewer than the more 600 Indian reserves they were supposed to administer.

${ }^{37}$ Miller (1997), 15.

${ }^{38}$ Hawker (2003), 21.

${ }^{39}$ See Harring (1998), 18.

${ }^{40}$ Miller (1997), 4.

${ }^{41}$ See Montgomery (1965).

${ }^{42}$ See $A$ History of the Vote in Canada, 1997, 58 and 86-87. Also LAC RG 9 series 111 vol. 5081, "Dominion of Canada, Military Voters Act 1917, Directions for Guidance of Voters". The Military Voters Act 1917 defined a "Military elector" as, " ... every person, male or female, who, being a British subject, whether or not ordinarily resident in Canada and whether or not an Indian, has been ... placed on active service as one of the Canadian Expeditionary Force ...".

${ }^{43}$ Ibid.

${ }^{44}$ Six Nations commissioned officers included Nursing Sister Charlotte Edith Anderson of the US Army Medical Corps, G.C. Monture, Frank Montour, O.M. Martin, James Moses, Alexander Smith Jr. MC, and Charles Denton Smith MC, and John Randolph Stacey originally from Kahnawake, but educated at Grand River at the Mohawk Institute. 
${ }^{45}$ Sally M. Weaver, "The Iroquois: The Consolidation of the Grand River Reserve in the Mid-Nineteenth Century, 1847-1875" in Edward S. Rogers, Donald B. Smith eds., Aboriginal Ontario: Historical Perspectives on the First Nations, (Toronto, 1994) p. 92

${ }^{46}$ Ibid, 44-45.

${ }^{47}$ Johnston (1964), 191-192.

${ }^{48}$ See Weaver (1975), 27-28, for a description of events surrounding the Grand River Navigation Co. investments.

${ }^{49}$ Weaver (1975), 122-124. The three chiefs were Jacob Jamieson, David Hill Jacket, and Jacob Hill.

${ }^{50}$ Campbell (2004), 187.

${ }^{51}$ See Noon (1949), 53-55.

${ }^{52}$ See Canada (1946b), 747.

${ }^{53}$ Noon (1949), 32 and 48-49.

${ }^{54}$ Campbell (2004), 187.

${ }^{55}$ Weaver (1994a), 201.

${ }_{57}^{56}$ Miller (1997), 10.

${ }^{57}$ Ibid, 11.

${ }^{58}$ Weaver (1994b), 239.

${ }^{59}$ Weaver (1975), 328.

${ }^{60} \mathrm{Ibid}, 345$.

${ }^{61}$ See Lackenbauer (2004), 205 concerning the problematic nature of attributions of false consciousness, and Lackenbauer (2007), 6-7 concerning academic studies privileging the causality of race-class-gender, and the rise of "consensus historiography".

${ }^{62}$ See Lackenbauer and McGowan (2007) for a description of Grand River involvement in the prewar militia, and for a detailed discussion of efforts to recruit Six Nations band members during 1914-1917.

${ }^{63}$ For recent treatments concerning Aboriginal involvement generally during the Seven Years' War, the American Revolution, and the War of 1812, see Horn (2007) and Graves (2007).

${ }^{64}$ For two contemporary overviews prepared by Indian Affairs deputy superintendent general Duncan Campbell Scott, see "The Canadian Indians and the Great World War" in William Dillon Otter, ed., Canada in the Great World War, Volume 3, (Toronto, 1919) pp. 285-328; and "The Indians and the Great War", in Annual Report of the Department of Indian Affairs for the Year ended March 31, 1919, (Ottawa, 1920) pp. 13-27.

${ }^{65}$ Dominion of Canada, Annual Report of the Department of Indian Affairs for the Year Ended March 31 , 1919, (Ottawa, 1920) p. 16. For the complete Six Nations Honour Roll including all who served, and those killed in action, died of wounds or illness, missing, wounded, and prisoner, see F. Douglas Reville, History of the County of Brant, Vol. II, (Brantford, 1919) pp. 618-620.

${ }^{66}$ Enos T. Montour, The Feathered U.E.L.' 's: An account of the life and times of certain Canadian native people, (Toronto, 1973) pp. 50-55.

${ }^{67}$ John A. Noon, Law and Government of the Grand River Iroquois, (New York, 1949) p. 60.

${ }^{68}$ Library \& Archives Canada (LAC), RG 10 Indian Affairs, Volume 2837, File 171,340, The Indian Magazine, Vol. III No. 4, January, 1896 pp. 2-3.

${ }^{69}$ LAC, RG 10 Indian Affairs, Reel C-11307, Volume 2991, File 215,977, Correspondence regarding the desire of numerous Indian bands across Canada to go to South Africa along with a possible contingent from the Six Nations Indians.

${ }_{70}^{7}$ Reville, History of the County of Brant, Vol. II, (Brantford, 1919) pp. 614-620.

71 Steven A. Bell, "The 107 "Timber Wolf' Battalion at Hill 70", Canadian Military History, Vol. 5, No. 1, (1996) pp. 73-78. For a biography of A.G. Campbell see Desmond Morton, Dictionary of Canadian Biography, Vol. XIV, (Toronto, 1998) pp. 172-173.

${ }^{72}$ See Zaslow (1964), "A Century Later - Canadian Memories of the War: Addresses at the Brock Centenary, 1912" by Colonel G. Sterling Ryerson, Angus Claude Macdonell, M.P., and Dr. James L. Hughes", 321-330.

${ }^{73}$ LAC, RG 10 Indian Affairs, Volume 3180, File 452,124-1, Indian Office Brantford, August 19 1914.

${ }^{74}$ See document H2 quoted in Wilson (1977), 172, "William Hamilton Merritt to Lieut.-Col. E.A. Stanton", (PAC, RG 7, G 21, v. 549, file 14071F): 500 pounds will be placed at the disposal of HRH for two companies to be composed of members of the Six Nations Indians, as a Centenary tribute to them for their vital aid in helping to save Canada to the Crown in 1812-14 ... 
${ }^{75}$ For a biography of W.H. Merritt see Paul Maroney and Stephen John Harris, Dictionary of Canadian Biography, Vol. XIV, (Toronto, 1998) pp. 757-760.

${ }^{76}$ LAC, RG 10 Indian Affairs, Volume 3180, File 452,124-1 Re. Recruiting of Indians $114^{\text {th }}$ O.S. Batt., CEF.

${ }^{77}$ Weaver (1994b), 245.

${ }^{78}$ Titley (1986), 114.

${ }^{79}$ Noon (1949), 65.

${ }^{80}$ Weaver (1975), 396.

${ }^{81}$ Moses (1973), 6.

${ }^{82}$ Among other effects, a significant impact of the 1985 Indian Act amendment known as Bill C-31 has been the infusion of a diversity of family names at Six Nations of the Grand River, previously unknown within the community. It is no longer possible to determine a band member's specific band enrolment based on surname alone.

${ }^{83}$ Bercuson \& Granatstein (1992), 72.

${ }^{84}$ DND \& Veterans Affairs Canada, 1992.

${ }^{85}$ See Canada (1920), 13.

${ }^{86}$ See Walker (1989), 6.

${ }^{87}$ More detailed descriptions concerning the particular brand of warfare in which many of the Six Nations troops engaged as infantry pioneers in the $107^{\text {th }}$ Battalion can be found in Bell (1996) and Mitchinson (1997). In particular see Bell (1996), 73, 75-76 and Mitchinson (1997), xi, 112-113, and 143.

${ }^{88}$ Quoted in Bercuson \& Granatstein (1992), 92. The complete official War Diary for the $107^{\text {th }}$ Battalion Canadian Pioneers, CEF, is available online at www.collectionscanada.ca/archivianet/020152_e.html. The complete finding aid is RG 9, Militia \& Defence, Series III-D-3, Volume 5010, Reel T-10859 File: 725

${ }^{89}$ Nicholson (1962), 532 describes 13 instances of disturbances including riots involving Canadian troops, the worst of these taking place at Kinmel Park, Wales, in 1919 amongst Canadian troops awaiting repatriation. Casualties included 5 killed and 23 wounded.

${ }^{90}$ See Canada (1946b), 747.

${ }^{91}$ See Kilduff (1997), 188 and 201.

${ }^{92}$ Photocopy of press clipping in the author's possession.

${ }^{93}$ See Spittal (1990) as an introductory volume.

${ }^{94}$ See " $37^{\text {th }}$ Haldimand Rifles", 300, The Quarterly Militia List of the Dominion of Canada, Published By

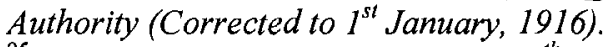

${ }_{95}$ Canadian Expeditionary Force, $114^{\text {th }}$ Battalion: Nominal Roll of Officers, Non-Commissioned Officers and Men, Embarkation Port: Halifax, Ship: S.S. 'Coronia', Date: October $31^{\text {st }}, 1916$. Issued With Militia Orders, 1917.

${ }^{96}$ Two headlines read, "Canadian Indians Visit To Glasgow" and "In War Paint and Feathers Canadian Indians Prepare To Leave For Front", each with accompanying text and photographs. No place or date, but probably Glasgow, late 1916. Clippings in author's possession.

${ }^{97}$ Parker, Arthur C. (probably 1918), "The American Indian In The World War" in The Southern Workman, 61-63. Photocopy in the author's possession.

${ }^{98}$ Elmer Jamieson to Augustus Jamieson, dateline 28 Jan. 1917, Army Post Office, London, England.

Original in the archives of the Woodland Centre, Brantford, ON. Photocopy with English translation in the author's possession.

${ }^{99}$ Halifax Herald, 12 December 1917, 5.

${ }^{100}$ LAC, RG 10 Indian Affairs, Volume 3181, File 452,124-1A, Ohsweken Council House, November 12, 1918 Minutes of Council Meeting.

${ }^{101}$ See Reville (1920), 617-618.

${ }^{102}$ See Jones (2004), 107-109,

The immediate problem confronting the Governments of all the belligerent nations was what to do with the millions of men returning from the trenches: men who for four long years had not known the comforts or certainties of civilian life, whose existence had been one of constant danger and destruction, who knew no trade or way of life other than the infliction of death ... [men who felt] a nostalgia for the war and a bitter contempt for the democratic politicians who had betrayed the blood sacrifice of those who had fought; and, last but by no means least, a dangerous thirst for violence and action for its own sake. 
${ }^{103}$ Cook (2007), 2.

${ }^{104}$ Vance (2005), 413.

${ }^{105}$ See Jones (2004).

${ }^{106}$ See Dorril (2007).

${ }^{107}$ Vance (1998), 230-231.

${ }^{108}$ Vance (2005), 420.

${ }^{109}$ Orr (1919), 53-54.

${ }^{110}$ Lackenbauer (2007), 7.

111 Titley (1986) remains the most detailed examination of Scott's mandate.

${ }^{112}$ See Bercuson \& Granatstein (1992), 93-94, for a description of social conditions on the Canadian homefront during and immediately following the Great War, and for returned soldiers' "inchoate rage" sometimes expressed against foreigners, non-combatants, and Quebecers.

${ }^{113}$ See Vance (1998), 116-120.

${ }^{114}$ Weaver (1975), 425-426.

${ }^{115}$ Weaver (1975) at 384 and 387 indicates a total of 160 signatures appearing on this petition. Presumably, of the 160 signatures given, 32 are of the veterans themselves with the remainder being their family members and other supporters. A photocopy in the author's possession includes the 32 veterans' signatures only.

${ }^{116}$ Reaman (1967), 123.

117 Titley (1986), 114-116.

${ }^{118}$ Ibid, 117.

119 Ibid, 117.

${ }^{120}$ Rostkowski (1989), 436.

${ }^{121}$ Meijer Drees (1995), 77-78.

${ }^{122}$ Ibid, 77.

${ }^{123}$ Rostkowski (1989), 440.

${ }^{124}$ Titley (1986), 123.

${ }^{125}$ See Cohen (2003), 118-127 for a brief history of Canada's foreign service from its inception to the outbreak of the Second World War.

${ }^{126}$ MacMillan (2005), 385.

${ }^{127}$ See the entry for Deskaheh (Levi General) by Donald B. Smith (2005) in Dictionary of Canadian

Biography Vol. XV, Toronto: University of Toronto Press, p. 279.

${ }^{128}$ Green \& Dickason (1989), 125-126.

${ }^{129}$ Hagopian (1997), 332-333.

${ }^{130}$ Ibid.

${ }^{131}$ Weaver (1975), 462 and 473 records that Thompson was appointed on 20 March 1923, and Morgan in October 1923 upon the conclusion of Thompson's commission.

${ }^{132}$ Titley (1986), 125.

${ }^{133}$ Weaver (1975), 468.

${ }^{134}$ Titley (1986), 115 and 119.

${ }^{135}$ Ibid (1986), 124. Weaver (1975), 465 indicates "some 27 persons", Six Nations band members, appearing as witnesses before the commissioner, "many of whom were now second generation Dehorners." ${ }^{136}$ A search warrant, with information laid by band members Hilton Hill and Elliott Moses (a lieutenant of Militia with the $37^{\text {th }}$ Haldimand Rifles) was executed by the RCMP in order to take into safekeeping the wampum which was used to open and close Council meetings. No actual belts were retrieved, however, the most significant wampum records having been sold off reserve during the 1890's by their nominal custodians. See Woodland Cultural Centre (1989), Council Fire: A Resource Guide, 27.

${ }^{137}$ See Weaver (1975), 495.

${ }^{138}$ Weaver (1975), 380.

${ }^{139}$ Sally M. Weaver, "The Iroquois: The Grand River Reserve in the Late Nineteenth and Early Twentieth Centuries, 18175-1945" in Rogers, Smith eds., Aboriginal Ontario: Historical Perspectives on First Nations, p. 249. Weaver remains the best published source on Six Nations of the Grand River political history. 


\section{References}

Abercrombie, Nicholas, Stephen Hill and Bryan S. Turner (1994), Penguin Dictionary of Sociology, third edition, London: Penguin Books.

Alfred, Taiaiake (1999), Peace, Power, Righteousness: An Indigenous Manifesto, Don Mills: Oxford University Press.

Allen, Robert S. (1992), His Majesty's Indian Allies: British Indian Policy in The Defence of Canada, 1774-1815, Toronto: Dundurn Press Limited.

Bell, Steven A. (1996), "The $107^{\text {th }}$ 'Timber Wolf' Battalion at Hill 70", Canadian Military History, Volume 5, Number 1, Spring 1996, 73-78.

Benincasa, James (1994), "Cultural Divisions and the Politics of Control: The Canadian Removal of the Six Nations Hereditary Council in 1924", unpublished MA thesis, University of Western Ontario.

Benn, Carl (1998), The Iroquois in the War of 1812, Toronto: University of Toronto Press.

Bercuson, David J. and J.L. Granatstein (1992), Dictionary of Canadian Military History, Toronto: Oxford University Press.

Borrows, John (1997), "Wampum at Niagara: The Royal Proclamation, Canadian Legal History, and Self-Government", chapter 6 in Asch, Michael, Ed. Aboriginal and Treaty Rights in Canada, Vancouver:UBC Press, 155-172.

Busch, Briton C., Ed. (2003), "Canada and the Great War The Western Front Association Papers", Montreal: McGill-Queen's University Press.

Campbell, William J. (2004), "Seth Newhouse, the Grand River Six Nations and the Writing of the Great Laws" in Ontario History, Volume XCVI, Number 2, Autumn 2004, 183-202.

Canada (1913), Handbook of Indians of Canada $\sim$ Published as an Appendix to the Tenth Report of the Geographic Board of Canada, Ottawa: Geographic Board of Canada.

Canada (1916), Letter from Officer Commanding $114^{\text {th }}$ Overseas Battalion, CEF, Re. Recruiting of Indians $114^{\text {th }}$ O.S. Batt., CEF. National Archives \& Library Canada, Record Group 10, Indian Affairs, vol. 3180, file 452,124-1.

Canada (1917a), Clanmothers' Petition, dateline Six Nations Indian Reserve, Grand River, Kanyengah Post Office, Brant County, Ont. Canada, January 31 ${ }^{\text {st }}$, 1917., National 
Archives \& Library Canada, Record Group 10, Indian Affairs, vol. 6767, file 452-15, pt. 1.

Canada (1917b), Soldiers' Petition, dateline France, Aug. 8, 1917, see Weaver (1975), 381-382.

Canada (1917c), "Canadian Expeditionary Force, 107 $7^{\text {th }}$ Battalion: Nominal Roll of Officers, Non-Commissioned Officers, and Men", issued with, Militia Orders, 1917.

Canada (1917d), "Canadian Expeditionary Force, $114^{\text {th }}$ Battalion: Nominal Roll of Officers, Non-Commissioned Officers, and Men", issued with, Militia Orders, 1917.

Canada (1918), "War Diaries 107 $7^{\text {th }}$ Pioneer Battalion 1917/03/01 - 1918/05/28" National Archives \& Library, Record Group 9, Militia \& Defence, Series III-D-3, vol. 5010, reel T-10859, file: 725 .

Canada (1919), Veterans' Petition, dateline Ohsweken, Ont. Sept. 1, 1919., National Archives \& Library Canada, Record Group 10, Indian Affairs, vol. 7930, file 32-32 pt. 2

Canada (1920), "The Indians and the Great War", extracted from, Annual Report of the Department of Indian Affairs for the Year ended March 31, 1919, Ottawa: J. de Labroquerie Tache, Printer to the King's Most Excellent Majesty, 13-27.

Canada (1924), Report by Col. Andrew T. Thompson, B.A., LL.B., Commissioner to investigate and enquire into the affairs of the Six Nations Indians, 1923, Ottawa: F.F. Acland, Printer to the King's Most Excellent Majesty.

Canada (1946a), "The Indians and the War", Canada Department of Mines and Resources Report of Indian Affairs Branch for the Fiscal Year Ended March 31, 1945, Ottawa: Edmond Cloutier, Printer to the King's Most Excellent Majesty, 160-161.

Canada (1946b), "Special Joint Committee of the Senate and the House of Commons Appointed to Examine and Consider the Indian Act", Minutes of Proceedings and Evidence No. 19, Tuesday, August 6, 1946, Witness: Mr. Oliver M. Martin, Magistrate, County of York Court, Toronto, Ontario. Ottawa: Edmond Cloutier, C.M.G., B.A. L.Ph., Printer to the King's Most Excellent Majesty and Controller of Stationery 1946.

Canada (1947), "Indians in the War", Canada Department of Mines and Resources Report of Indian Affairs Branch for the Fiscal Year Ended March 31, 1946, Ottawa: Edmond Cloutier, King's Printer and Controller of Stationery, 195-196.

Canada (1997), A History of the Vote in Canada, Ottawa: Minister of Public Works and Government Services for the Chief Electoral Officer of Canada. 
Cohen, Andrew (2003), While Canada Slept: How We Lost Our Place in the World, Toronto: McClelland \& Stewart Ltd.

Committee of Chiefs (1911), "Traditional History of the Confederacy of the Six Nations, prepared by a Committee of the Chiefs", Transactions of the Royal Society of Canada, Section II, 1911, presented by Duncan Campbell Scott, FRSC, on May 16, 1911.

Cook, Tim (2007), At The Sharp End: Canadians Fighting The Great War 1914-1916, Toronto: Viking Canada/The Penguin Group.

Cork, Ella (1962), The Worst of the Bargain, San Jacinto: Foundation for Social Research.

Cottam, Barry S. (1997), Aboriginal Peoples and Archives: a brief history of aboriginal and European relations in Canada, Ottawa: National Archives of Canada/Minister of Public Works and Government Services Canada.

Craig, Gerald M. (1963), Upper Canada: The Formative Years 1784-1841, Toronto: McClelland and Steward Limited.

Dorril, Stephen (2007), Blackshirt: Sir Oswald Mosley and British Fascism, London: Penguin Books.

Easthope, Anthony and Kate McGowan (2004), A Critical and Cultural Theory Reader, second edition. Toronto: University of Toronto Press.

Engels, Friedrich (1884), The Origin of the Family, Private Property and the State, London: Penguin Books Classics edition of 1986 with an introduction by Michele Barrett.

Evans, Graham and Jeffrey Newnham (1998), Penguin Dictionary of International Relations, London: Penguin Books.

Gaffen, Fred (1985), Forgotten Soldiers, Penticton: Theytus Books Ltd.

Goldenweiser, A.A. (1914), "Functions of Women in Iroquois Society", American Anthropologist, New Series, Vol. 17, 1915, 376-377. Reprinted in Spittal, 1990, 51-52.

Graves, Donald E. (2007), "His Majesty's Aboriginal Allies: The Contribution of the Indigenous Peoples of North America to the Defence of Canada during the War of 1812", chapter 2 in Lackenbauer, P. Whitney and Craig Leslie Mantle, Eds. Aboriginal Peoples and the Canadian Military: Historical Perspectives, Kingston: Canadian Defence Academy Press, 29-56. 
Green, L.C. and Olive P. Dickason (1989), The Law of Nations and the New World, Edmonton: University of Alberta Press.

Hagopian, John S. (1997), "Joseph Brant vs. Peter Russell: A Re-examination of the Six Nations' Land Transactions in the Grand River Valley", Histoire Sociale/Social History, Vol. XXX, No. 60, November 1997, pp. 300-333.

Harring, Sidney L. (1998), White Man's Law: Native People in Nineteenth-Century Canadian Jurisprudence, Toronto: University of Toronto Press/The Osgoode Society for Canadian Legal History.

Hawker, Ronald W. (2003), Tales of Ghosts: First Nations Art in British Columbia, 1922-1961, Vancouver: University of British Columbia Press.

Henry, Wade A. (2000), "Imagining the Great White Mother and the Great King: Aboriginal Tradition and Royal Representation at the "Great Pow-wow' of 1901", Journal of the Canadian Historical Association 2000, Edmonton: Canadian Historical Association.

Hitsman, J. Mackay (1968), Safeguarding Canada, 1763-1871, Toronto: University of Toronto Press.

Horn, Bernd (2007), “'A Necessary Evil?': Indians as Allies in the Struggle for North America, 1754-1760", chapter 1 in Lackenbauer, P. Whitney and Craig Leslie Mantle, Eds. Aboriginal Peoples and the Canadian Military: Historical Perspectives, Kingston: Canadian Defence Academy Press, 1-27.

Johnson, E. Pauline (1913), "The Delaware Idol", The Shagganappi, Toronto: William Briggs, 180-190.

Johnston, Charles M., Ed. (1964), The Valley of the Six Nations: A Collection of Documents on the Indian Lands of the Grand River, Toronto: The Champlain Society/University of Toronto Press.

Jones, Nigel (2004), The Birth of the Nazis, London: Constable \& Robinson Ltd.

Kilduff, Peter (1997), The Red Baron Combat Wing: Jagdgeschwader von Richtofen in Battle, London: Arms and Armour Press.

Lackenbauer, P. Whitney (2004), "The Irony and the Tragedy of Negotiated Space: A Case Study on Narrative Form and Aboriginal-Government Relations During The Second World War", Journal of the Canadian Historical Association 2004 Revue de la SHC, New Series, Vol. 15, 177-206. 
Lackenbauer, P. Whitney (2007), Battle Grounds: The Canadian Military and Aboriginal Lands, Vancouver: University of British Columbia Press.

Lackenbauer, P. Whitney and Craig Leslie Mantle, Eds. (2007), Aboriginal Peoples and the Canadian Military: Historical Perspectives, Kingston: Canadian Defence Academy Press.

Lackenbauer, P. Whitney and McGowan, Katharine (2007), "Competing Loyalties in a Complex Community: Enlisting the Six Nations in the Canadian Expeditionary Force, 1914-1917', chapter 4 in Lackenbauer, P. Whitney and Craig Leslie Mantle, Eds. Aboriginal Peoples and the Canadian Military: Historical Perspectives, Kingston: Canadian Defence Academy Press, 89-115.

Mackenzie, David, Ed., (2005), "Canada and the First World War: Essays in Honour of Robert Craig Brown", Toronto: University of Toronto Press.

MacMillan, Margaret (2005), "Canada and the Peace Settlements", Canada and the First World War: Essays in Honour of Robert Craig Brown, Toronto: University of Toronto Press, 379-408.

McCann, Kelly (1994), "The Six Nations Indians and World War One", research essay, Carleton University, Ottawa.

Meijer Drees, Laurie (1995), "Nationalism, The League of Nations and the Six Nations of the Grand River: Introduction to Documents One Through Five", Native Studies Review, Vol. 10, No. 1, 75-88.

Miller, J.R. (1997), Canada and the Aboriginal Peoples 1867-1927, Canadian Historical Association Historical Booklet No. 57, Ottawa: The Canadian Historical Association.

Miller, J.R. (2000), Skyscrapers Hide the Heavens: A History of Indian-White Relations in Canada, third edition, Toronto: University of Toronto Press.

Mitchinson, K.W. (1997), Pioneer Battalions in the Great War: Organized and Intelligent Labour, London: Leo Cooper.

Montgomery, Malcolm (1963), "The Legal Status of the Six Nations Indians in Canada", Ontario History, Vol. LV, No. 2, 93-105.

Montgomery, Malcolm (1965), "The Six Nations Indians and the Macdonald Franchise", Ontario History, Vol. LVII, No. 1, 13-25.

Montour, Enos T. (1973), The Feathered U.E.L's: An account of the life and times of certain Canadian native people, Toronto: United Church of Canada. 
Montour, Nathan (1971), The Life Story of My Grandparents, Ohsweken: privately printed.

Monture-Angus, Patricia (1999), Journeying Forward: Dreaming First Nations Independence, Halifax: Fernwood Publishing.

Morgan, Lewis Henry (1851), League of the Ho-de-no-sau-nee, or Iroquois, Secaucus: Citadel Press edition of 1962 with an introduction by William N. Fenton.

Morgan, Lewis Henry (1881), Houses and House-Life of the American Aborigines, Chicago: The University of Chicago Press/Phoenix Books edition of 1965 with an introduction by Paul Bohannan.

Moses, Elliott (1968), "Seventy-Five Years of Progress of the Six Nations of the Grand River", Waterloo Historical Society, Vol. 56, 1968, 19-26.

Moses, Elliott (1973), "The Six Nations Dehorners Association, Finally Called the Six Nations Rights Association", Elliott Moses papers, National Archives \& Library Canada, MG 10, C 169, Finding Aid No. 1109. Photocopy in the author's possession.

Moses, Elliott (1975?), "Historical sketch of the introduction of the elective system of council on the Six Nations Reservation in the Year 1924", Elliott Moses papers, National Archives \& Library Canada, MG 10, C 169, Finding Aid No. 1109. Photocopy in the author's possession.

Moses, John, with Donald Graves and Warren Sinclair (2004), A Sketch Account of Aboriginal Peoples in the Canadian Military, Ottawa: Minister of National Defence/Directorate of History \& Heritage, e-publication available in downloadable format at <www.dnd.ca/hr/dhh/downloads/Official_Histories/sketch_e.pdf $>$

Moses, John (2007), "The Return of the Native: Six Nations Veterans and Political Change at the Grand River Reserve, 1917-1924", chapter 5 in Lackenbauer, P. Whitney and Craig Leslie Mantle, Eds. Aboriginal Peoples and the Canadian Military: Historical Perspectives, Kingston: Canadian Defence Academy Press, 117-128.

Nicholson, Colonel G.W.L. (1962), Official History of the Canadian Army in the First World War, Ottawa: Queen's Printer and Controller of Stationary.

Noon, John A. (1949), Law and Government of the Grand River Iroquois, New York: Viking Fund Publications in Anthropology.

Orr, Dr. R.B. (1919), Thirty-First Annual Archaeological Report 1919, Toronto: A.T. Wilgress, Printer to the King's Most Excellent Majesty, printed by order of the Legislative Assembly of Ontario. 
Reaman, G. Elmore (1967), The Trail of the Iroquois Indians: How the Iroquois Nation Save Canada for the British Empire, Toronto: Peter Martin Associates Limited.

Reville, F. Douglas (1920), History of the County of Brant, Vol II, Brantford: The Hurley Printing Company, Limited.

[Contains a nominal roll of all Six Nations band members serving during the Great War]

Reid, Gerald F. (2004), Kahnawà:ke: Factionalism, Traditionalism, and Nationalism in a Mohawk Community, Lincoln: University Nebraska Press.

Rostkowski, Joelle (1989), “The Redman's Appeal for Justice: Deskaheh and the League of Nations" in Christian F. Feest, Ed., Indians and Europe: An Interdisciplinary Collection of Essays, Aachen, 435-453.

Rostkowski, Joelle (1995), "Deskaheh's Shadow: Indians on the International Scene" in European Review of Native American Studies, Vol. 9, No. 2, 1-4.

Scott, Duncan Campbell (1919), "The Canadian Indians and the Great World War", Appendix I to Volume III, "Guarding the Channel Ports", of Canada in the Great World War: An Authentic Account of the Military History of Canada From the Earliest Days to the Close of the War of Nations, by Various Authorities, Toronto: United Publishers of Canada Limited, 285-328.

Sheffield, R. Scott (1996), "Of Pure European Descent and of the White Race: Recruitment Policy and Aboriginal Canadians, 1939-1945", Canadian Military History, Vol. 5, No. 1, 8-15.

Shimony, Annemarie Anrod (1961), Conservatism Among the Iroquois at the Six Nations Reserve, New Haven: Yale University Publications in Anthropology.

Speck, Frank G. and Jesse Moses (1945), The Celestial Bear Comes Down to Earth: The Bear Sacrifice Ceremony of the Munsee-Mahican in Canada as Related by Nekatcit, Reading, PA: Reading Museum and Art Gallery Scientific Publications Number 7.

Spittal, W.G., Ed. (1990), Iroquois Women: An Anthology, Ohsweken: Iroqrafts Reprints.

Stanley, George F.G. (1989), Toil \& Trouble: Military Expeditions to Red River, Toronto: Dundurn Press/Canadian War Museum Historical Publication No. 25.

Summerby, Janice (2005), Native Soldiers, Foreign Battlefields, second edition, Ottawa: Veterans Affairs Canada.

Telford, Rhonda (2001), "The Central Ontario Anishinabe and the Rebellion, 18301840", Actes du Trente-Deuxieme Congres de Algonquinistes, Winnipeg: L'Universite du Manitoba, 552-570. 
Titley, E. Brian (1986), A Narrow Vision: Duncan Campbell Scott and the Administration of Indian Affairs in Canada, Vancouver: University of British Columbia Press.

Trevithick, Scott R. (1998), "Conflicting Outlooks: The Background to the 1924 Deposing of the Six Nations Hereditary Council", unpublished MA theses, University of Calgary.

Vance, Jonathan F. (1998), Death So Noble: Memory, Meaning, and the First World War, Vancouver: University of British Columbia Press.

Vance, Jonathan F. (2005), "Remembering Armageddon", Canada and the First World War: Essays in Honour of Robert Craig Brown, Toronto: University of Toronto Press, 409-433.

Walker, James W. St. G. (1989), "Race and Recruitment in World War 1: Enlistment of Visible Minorities in the Canadian Expeditionary Force", Canadian Historical Review, Vol. LXX, No. 1, 1-25.

Weaver, Sally M. (1972), Medicine and Politics among the Grand River Iroquois: A Study of the Non-Conservatives, Ottawa: National Museum of Man/National Museums of Canada, Publications in Ethnology No. 4.

Weaver, Sally M. (1975), Iroquois Politics 1847-1940, an unpublished manuscript in the archives of the Canadian Museum of Civilization, Gatineau: Weaver, Sally M. Coll: (Acc 98/55), Box 468 F.28

Weaver, Sally M. (1994a), "The Iroquois: Consolidation of the Grand River Reserve in the Mid-Nineteenth Century, 1847-1875", Chapter 9 in Aboriginal Ontario: Historical Perspectives on the First Nations, Edward S. Rogers \& Donald B. Smith, Eds., pp. 182212.

Weaver, Sally M. (1994b), "The Iroquois: The Grand River Reserve in the Late Nineteenth and Early Twentieth Centuries, 1875-1945", Chapter 10 in Aboriginal Ontario: Historical Perspectives on the First Nations, Edward S. Rogers \& Donald B. Smith, Eds., pp. 213-257.

Widdowson, Frances (2004), "Inventing Nationhood: The Political Economy of Aboriginal Claims to Self-Determination in the Context of Quebec Sovereignty", a presentation before the Annual Conference of the Canadian Political Science Association, Winnipeg, June 5, 2004.

Wilson, Barbara M., Ed. (1977), Ontario and the First World War 1914-1918: A Collection of Documents, Toronto: The Champlain Society. 
Zaslow, Morris (1964), The Defended Border: Upper Canada and the War of 1812, Toronto: The Macmillan Company of Canada Limited. 